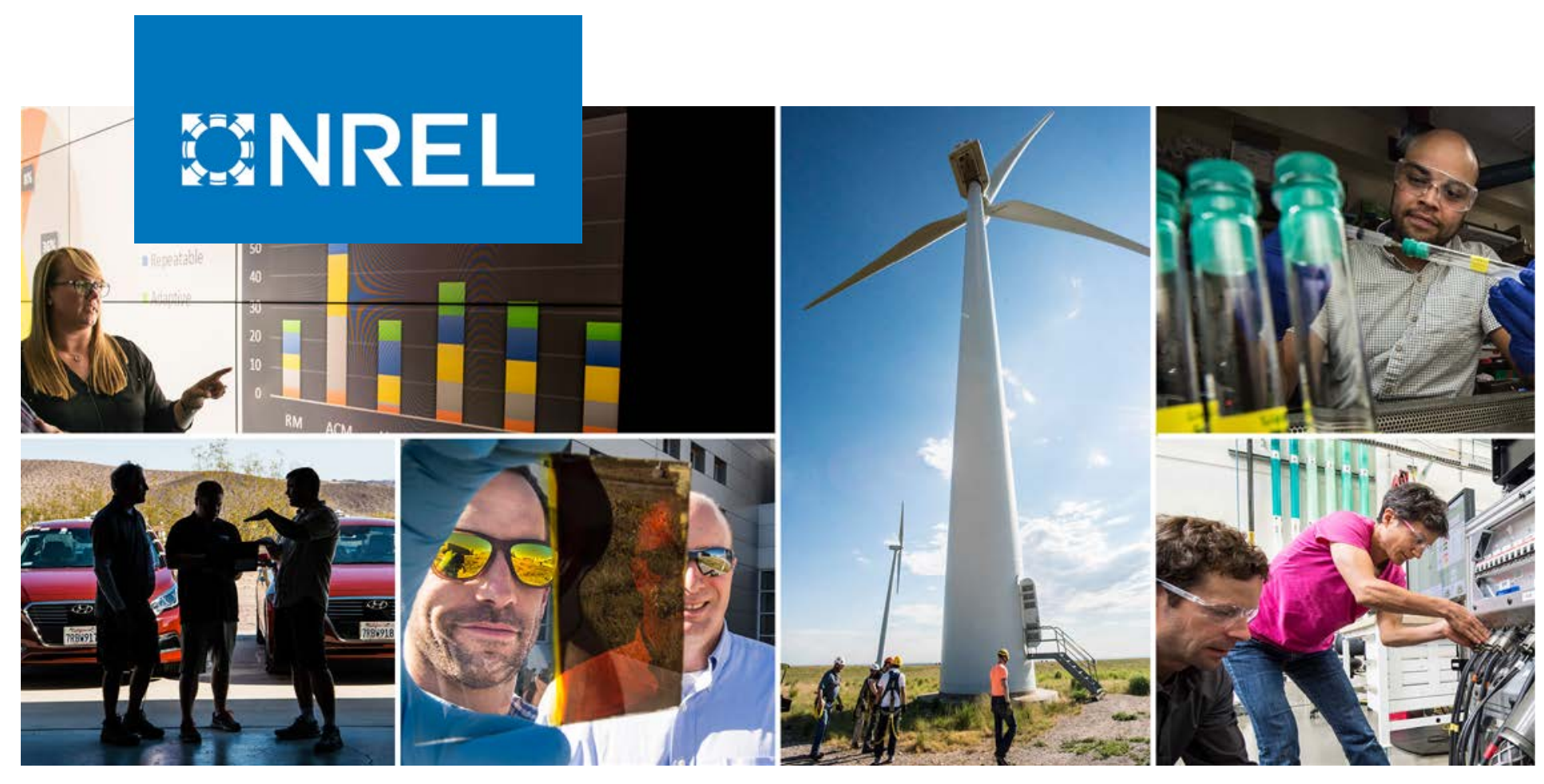

\title{
2020 Cost of Wind Energy Review
}

\author{
Tyler Stehly and Patrick Duffy
}

National Renewable Energy Laboratory

NREL is a national laboratory of the U.S. Department of Energy

Office of Energy Efficiency \& Renewable Energy

Operated by the Alliance for Sustainable Energy, LLC

This report is available at no cost from the National Renewable Energy Laboratory (NREL) at www.nrel.gov/publications.

\section{Technical Report}

NREL/TP-5000-81209

Revised January 2022 


\title{
GNREL
}

\section{Cost of Wind Energy Review}

\author{
Tyler Stehly and Patrick Duffy \\ National Renewable Energy Laboratory
}

\section{Suggested Citation}

Stehly, Tyler and Patrick Duffy. 2021. 2020 Cost of Wind Energy Review. Golden, CO:

National Renewable Energy Laboratory. NREL/TP-5000-81209.

https://www.nrel.gov/docs/fy220sti/81209.pdf.

NREL is a national laboratory of the U.S. Department of Energy Office of Energy Efficiency \& Renewable Energy Operated by the Alliance for Sustainable Energy, LLC

This report is available at no cost from the National Renewable Energy Laboratory (NREL) at www.nrel.gov/publications.

Contract No. DE-AC36-08GO28308
Technical Report

NREL/TP-5000-81209

Revised January 2022

National Renewable Energy Laboratory 15013 Denver West Parkway Golden, CO 80401

303-275-3000 • www.nrel.gov 


\section{NOTICE}

This work was authored by the National Renewable Energy Laboratory, operated by Alliance for Sustainable Energy, LLC, for the U.S. Department of Energy (DOE) under Contract No. DE-AC36-08GO28308. Funding provided by the U.S. Department of Energy Office of Energy Efficiency and Renewable Energy Wind Energy Technologies Office. The views expressed herein do not necessarily represent the views of the DOE or the U.S. Government.

This report is available at no cost from the National Renewable Energy Laboratory (NREL) at www.nrel.gov/publications.

U.S. Department of Energy (DOE) reports produced after 1991 and a growing number of pre-1991 documents are available free via www.OSTI.gov.

Cover Photos by Dennis Schroeder: (clockwise, left to right) NREL 51934, NREL 45897, NREL 42160, NREL 45891, NREL 48097, NREL 46526.

NREL prints on paper that contains recycled content. 


\section{Errata}

This report, originally published in December 2021, has been revised in January 2022 to correct the reference residential and commercial distributed wind levelized cost of energy values presented in the last bullet point of the Executive Summary on page xiv. 


\section{Acknowledgments}

The authors would like to thank Patrick Gilman (U.S. Department of Energy Office of Energy Efficiency and Renewable Energy Wind Energy Technologies Office [WETO]) for supporting this research. Thanks also to Gage Reber (contractor to WETO) and Daniel Beals of Allegheny Science and Technology (contractor to WETO) for reviewing prior versions of this manuscript. Thank you to Ryan Wiser and Mark Bolinger (Lawrence Berkeley National Laboratory) and Alice Orrell (Pacific Northwest National Laboratory) for their analysis of wind project market data that informed this analysis and to Travis Williams (National Renewable Energy Laboratory) for work in developing the national wind supply curves. Thanks also to Philipp Beiter and Eric Lantz (National Renewable Energy Laboratory) for their technical guidance, contributions, and review of prior versions of this manuscript. Any remaining errors or omissions are the sole responsibility of the authors. 


\section{List of Acronyms}

\begin{tabular}{|c|c|}
\hline AEP & annual energy production \\
\hline ATB & Annual Technology Baseline \\
\hline BOS & balance of system \\
\hline CapEx & capital expenditures \\
\hline CRF & capital recovery factor \\
\hline CSM & Cost and Scaling Model \\
\hline DOE & U.S. Department of Energy \\
\hline FCR & fixed charge rate \\
\hline FY & fiscal year \\
\hline GPRA & Government Performance and Results Act \\
\hline GW & gigawatt \\
\hline IEC & International Electrotechnical Commission \\
\hline $\mathrm{kW}$ & kilowatt \\
\hline LandBOSSE & $\begin{array}{l}\text { Land-based Balance of System Systems } \\
\text { Engineering }\end{array}$ \\
\hline LCOE & levelized cost of energy \\
\hline $\mathrm{m}$ & meter \\
\hline $\mathrm{m} / \mathrm{s}$ & meters per second \\
\hline MACRS & Modified Accelerated Cost Recovery System \\
\hline MW & megawatt \\
\hline MWh & megawatt-hour \\
\hline NREL & National Renewable Energy Laboratory \\
\hline O\&M & operation and maintenance \\
\hline OpEx & operational expenditures \\
\hline ORCA & Offshore Wind Regional Cost Analyzer \\
\hline PTC & production tax credit \\
\hline USD & U.S. dollars \\
\hline WACC & weighted-average cost of capital \\
\hline WETO & Wind Energy Technologies Office \\
\hline $\mathrm{yr}$ & year \\
\hline
\end{tabular}




\section{Executive Summary}

This report uses representative utility-scale and distributed wind energy projects to estimate the levelized cost of energy (LCOE) for land-based and offshore wind power plants in the United States. Data and results detailed here are derived from 2020 commissioned plants and representative industry data as well as state-of-the-art modeling capabilities. Modeling is conducted to provide more granular detail on specific cost categories. This report represents the tenth annual installment and is intended to provide insight into current component-level costs as well as a basis for understanding variability in wind energy LCOE across the country.

The primary elements of this 2020 report include:

- Estimated LCOE for a representative, land-based wind energy project installed in a moderate wind resource in the United States

- Estimated LCOE for a representative offshore, fixed-bottom, wind energy project installed in the North Atlantic region of the United States and a representative offshore, floating, wind energy project installed off the Pacific Coast region of the United States

- Updated LCOE estimates for representative residential- and commercial-scale distributed wind projects installed in a moderate wind resource in the United States

- Sensitivity analyses showing the range of effects that basic LCOE variables could have on the cost of wind energy for land-based and offshore wind

- Updated national supply curves for land-based and offshore wind energy based on geographically specific wind resource conditions paired with approximate wind turbine cost characteristics

- Updated Fiscal Year 2021 values for land-based and offshore wind energy used for Government Performance and Results Act (GPRA) reporting as well as illustrated progress toward established GPRA targets.

\section{Key Inputs and Results}

Throughout this report, the representative land-based, offshore, and distributed wind energy project types are referred to as "reference projects." Table ES1, Table ES2, Table ES3, Table ES4, and Table ES5 summarize the basic LCOE inputs and outputs for the reference land-based, fixed-bottom, and floating offshore wind and residential and commercial distributed wind energy projects. The LCOE inputs include project capital expenditures (CapEx), operational expenditures (OpEx), project financing (characterized by a fixed charge rate $[\mathrm{FCR}]$ ) and the respective turbine capacity factor associated with the net annual energy production estimates. Unless specifically stated, all data and analysis in the report are in 2020 U.S. dollars. 
Table ES1. Summary of the Land-Based Reference Project Using 2.8-megawatt (MW) Wind Turbines

\begin{tabular}{|l|c|c|}
\hline & $\begin{array}{c}\text { 2.8-MW Land-Based } \\
\text { Wind Turbine } \\
\text { (\$/kilowatt [kW]) }\end{array}$ & $\begin{array}{c}\text { 2.8-MW Land-Based } \\
\text { Wind Turbine } \\
\text { (\$/megawatt- } \\
\text { hour [MWh] }\end{array}$ \\
\hline Turbine capital cost & 1,021 & 15.9 \\
\hline Balance of system & 319 & 5.0 \\
\hline Financial costs & 122 & 1.9 \\
\hline Capital expenditures (CapEx) & $\mathbf{1 , 4 6 2}$ & $\mathbf{2 2 . 8}$ \\
\hline & & $\mathbf{1 1 . 5}$ \\
\hline Operational expenditures (OpEx; \$/kW/year [yr]) & $\mathbf{4 3}$ & \\
\hline Fixed charge rate (FCR; \%) [real] & \multicolumn{2}{|c|}{$3.78 \%$} \\
\hline Net annual energy production (MWh/MW/yr) & \multicolumn{2}{|c|}{$\mathbf{3 4}$} \\
\hline Net capacity factor (\%) & \multicolumn{2}{|c|}{} \\
\hline TOTAL LCOE (\$/MWh) & \multicolumn{2}{|c|}{} \\
\hline
\end{tabular}

Table ES2. Summary of the Fixed-Bottom Reference Project Using 8.0-MW Wind Turbines

\begin{tabular}{|c|c|c|}
\hline & $\begin{array}{c}\text { 8.0-MW Offshore Wind } \\
\text { Turbine }\end{array}$ & $\begin{array}{c}\text { 8.0-MW Offshore Wind } \\
\text { Turbine }\end{array}$ \\
\hline & $(\$ / k W)$ & (\$/MWh) \\
\hline Turbine capital cost & 1,301 & 17.7 \\
\hline Balance of system & 1,782 & 24.2 \\
\hline Financial costs & 672 & 9.1 \\
\hline CapEx & 3,756 & 51.0 \\
\hline OpEx (\$/kW/yr) & 110 & 25.8 \\
\hline FCR (real) [\%] & \multicolumn{2}{|c|}{$5.8 \%$} \\
\hline Net annual energy production (MWh/MW/yr) & \multicolumn{2}{|c|}{4,283} \\
\hline Net capacity factor (\%) & \multicolumn{2}{|c|}{$48.9 \%$} \\
\hline Total LCOE (\$/MWh) & \multicolumn{2}{|c|}{77} \\
\hline
\end{tabular}


Table ES3. Summary of the Floating Offshore Wind Reference Project Using 8.0-MW Turbines

\begin{tabular}{|c|c|c|}
\hline & $\begin{array}{l}\text { 8.0-MW Floating } \\
\text { Offshore Wind Turbine } \\
\qquad(\$ / k W)\end{array}$ & $\begin{array}{l}\text { 8.0-MW Floating } \\
\text { Offshore Wind Turbine } \\
\text { (\$/MWh) }\end{array}$ \\
\hline Turbine capital cost & 1,301 & 22.7 \\
\hline Balance of system & 3,234 & 56.5 \\
\hline Financial costs & 816 & 14.3 \\
\hline CapEx & 5,351 & 93.5 \\
\hline OpEx (\$/kW/yr) & 118 & 35.4 \\
\hline FCR (real) [\%] & \multicolumn{2}{|c|}{$5.8 \%$} \\
\hline Net annual energy production (MWh/MW/yr) & \multicolumn{2}{|c|}{3,332} \\
\hline Net capacity factor (\%) & \multicolumn{2}{|c|}{$38.0 \%$} \\
\hline Total LCOE (\$/MWh) & \multicolumn{2}{|c|}{129} \\
\hline
\end{tabular}

Note: GPRA values are not reported for floating offshore wind technology.

Table ES4. Summary of the Residential Distributed Wind Reference Project Using a 20-kW Wind Turbine

\begin{tabular}{|c|c|c|}
\hline & $\begin{array}{c}\text { 20-kW Residential } \\
\text { Wind Turbine } \\
\text { (\$/kW) }\end{array}$ & $\begin{array}{l}\text { 20-kW Residential } \\
\text { Wind Turbine } \\
\text { (\$/MWh) }\end{array}$ \\
\hline Turbine CapEx & 2,575 & 62.4 \\
\hline Balance-of-system CapEx & 3,100 & 75.1 \\
\hline Total CapEx & 5,675 & 137.5 \\
\hline OpEx (\$/kW/yr) & 35 & 13.6 \\
\hline FCR (real) [\%] & \multicolumn{2}{|c|}{$6.2 \%$} \\
\hline Net annual energy production ( $\mathrm{kWh} / \mathrm{kW} / \mathrm{yr})$ & \multicolumn{2}{|c|}{2,580} \\
\hline Net capacity factor (\%) & \multicolumn{2}{|c|}{$29.5 \%$} \\
\hline TOTAL LCOE (\$/MWh) & \multicolumn{2}{|c|}{151} \\
\hline
\end{tabular}


Table ES5. Summary of the Commercial Distributed Wind Reference Project Using a 100-kW Wind Turbine

\begin{tabular}{|c|c|c|}
\hline & $\begin{array}{c}\text { 100-kW Commercial } \\
\text { Wind Turbine } \\
(\$ / k W)\end{array}$ & $\begin{array}{l}\text { 100-kW Commercial } \\
\text { Wind Turbine } \\
\text { (\$/MWh) }\end{array}$ \\
\hline Turbine CapEx & 2,530 & 51.0 \\
\hline Balance-of-system CapEx & 1,770 & 35.7 \\
\hline Total CapEx & 4,300 & 86.6 \\
\hline OpEx (\$/kW/yr) & 35 & 12.3 \\
\hline FCR (real) [\%] & \multicolumn{2}{|c|}{$5.7 \%$} \\
\hline Net annual energy production (kWh/kW/yr) & \multicolumn{2}{|c|}{2,846} \\
\hline Net capacity factor (\%) & \multicolumn{2}{|c|}{$32.5 \%$} \\
\hline TOTAL LCOE (\$/MWh) & \multicolumn{2}{|c|}{99} \\
\hline
\end{tabular}

In this report, 2020 installed land-based wind energy project data and costs are primarily informed from Wiser and Bolinger (2021). These data are supplemented with outputs from the National Renewable Energy Laboratory's (NREL's) cost models to obtain wind turbine and balance-of-system component cost details. The offshore reference project data are estimated from installed 2020 global offshore wind projects as well as data collected from U.S.-proposed projects. The assumed wind resource regime and geospatial power plant characteristics (e.g., water depth and distance from shore) for the offshore reference plants are comparable to sites on the U.S. North Atlantic and Pacific Coast and are detailed in Appendix A. The residential and commercial distributed wind reference projects are informed by 2019 market data from Orrell et al. (2020) because the market data for distributed wind energy projects in 2020 only comprised retrofits or upgrades (Orrell et al. 2021). The distributed wind balance-of-system values are estimated from NREL's Balance-of-System Cost Model for Land-Based Wind (Eberle et al. 2019). The details for land-based, offshore, and distributed wind representative sites are reported in Appendix B.

The four major component LCOE categories - wind turbine CapEx, balance-of-system CapEx, finance CapEx, and OpEx - and many subcategories are represented in Figure ES1, Figure ES2, Figure ES3, and Figure ES4. These figures include wind turbine (e.g., wind turbine components), balance of system (e.g., development, electrical infrastructure, assembly, and installation), and financial costs (e.g., insurance and construction financing). Most of the land-based reference project LCOE (46.4\%) is in the wind turbine itself, whereas the balance of system is the major contributor for the fixed-bottom and floating offshore reference projects, making up $31.5 \%$ and $43.8 \%$, respectively. The LCOE categories for the representative distributed wind energy projects only consider the turbine, balance of system, and operation and maintenance (O\&M) costs because there is limited empirical data on more detailed system cost breakdown for distributed wind projects. For the representative residential distributed wind energy project, the balance-of-system cost comprises a majority of the LCOE at $49.8 \%$, whereas the commercial 
distributed wind project cost is accounted for by the wind turbine itself, contributing $51.6 \%$ of the LCOE.

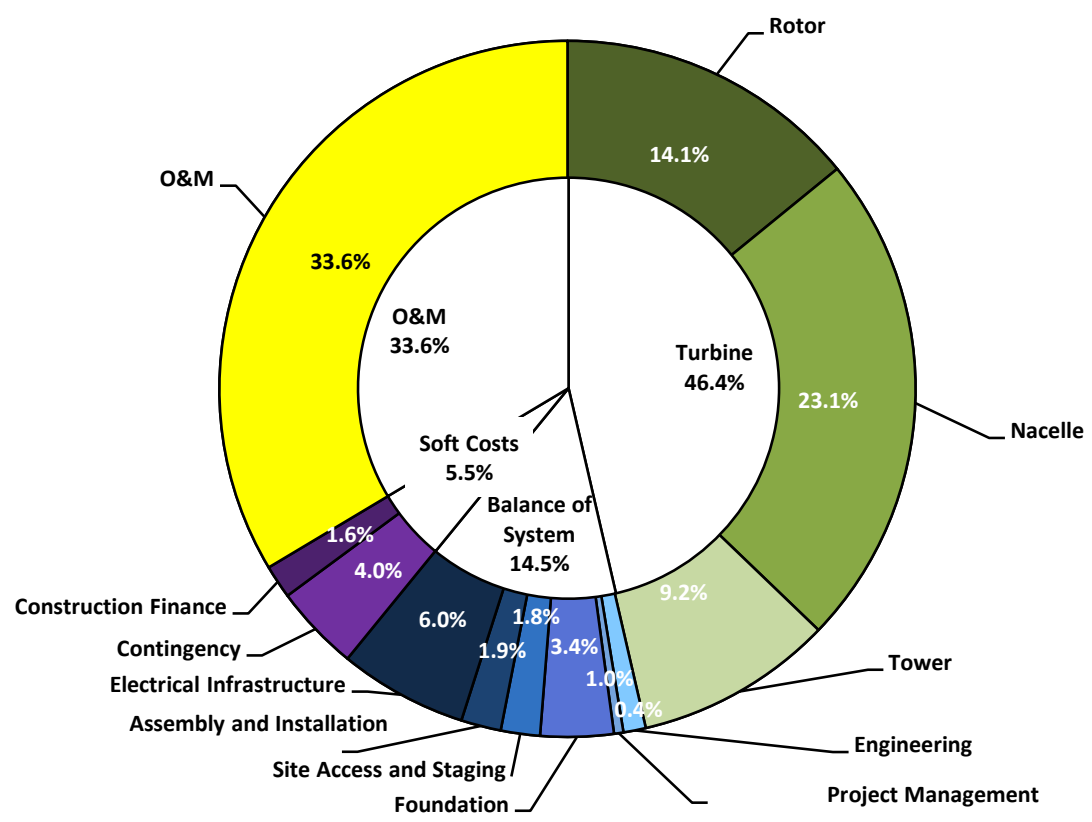

Figure ES1. Component-level LCOE contribution for the 2020 land-based wind reference project operating for 25 years

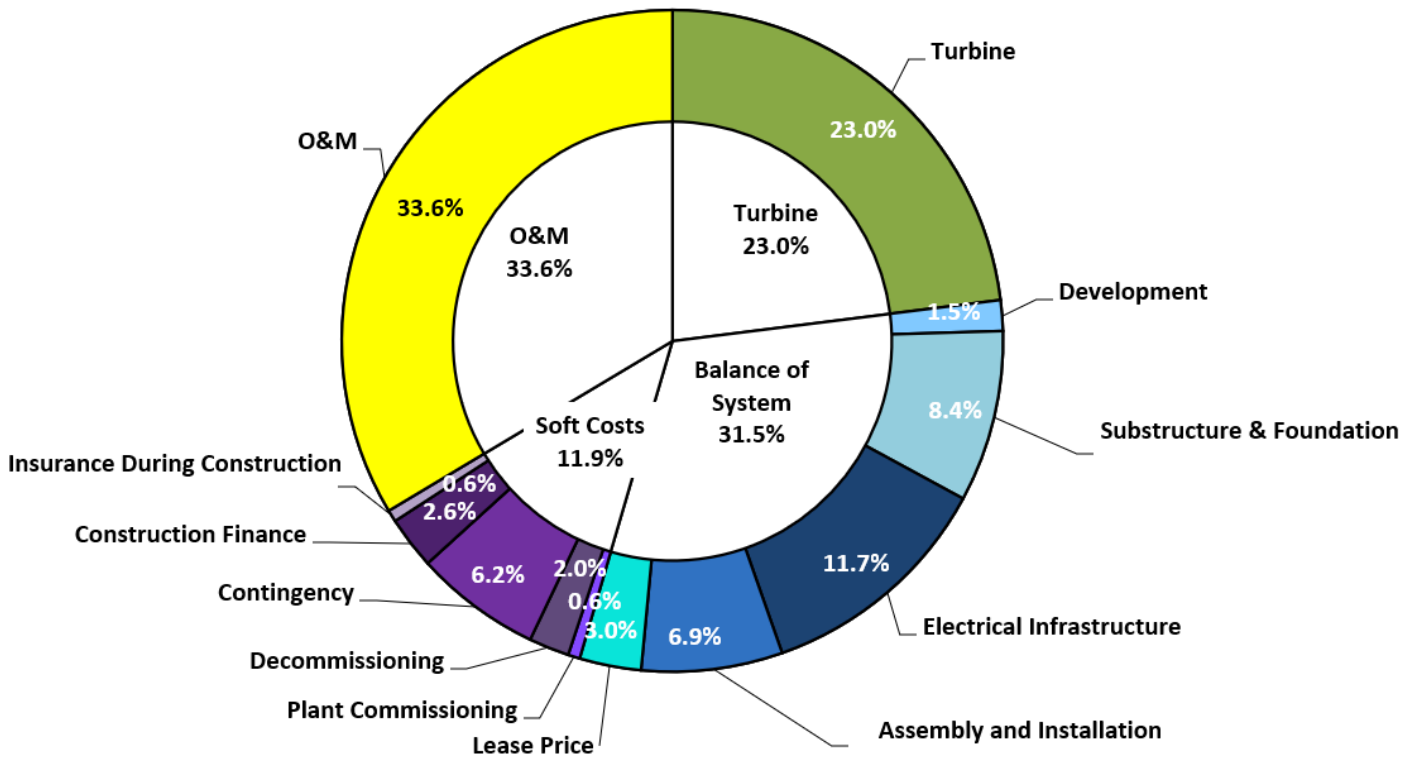

Figure ES2. Component-level LCOE contribution for the 2020 fixed-bottom offshore wind reference project operating for 25 years 


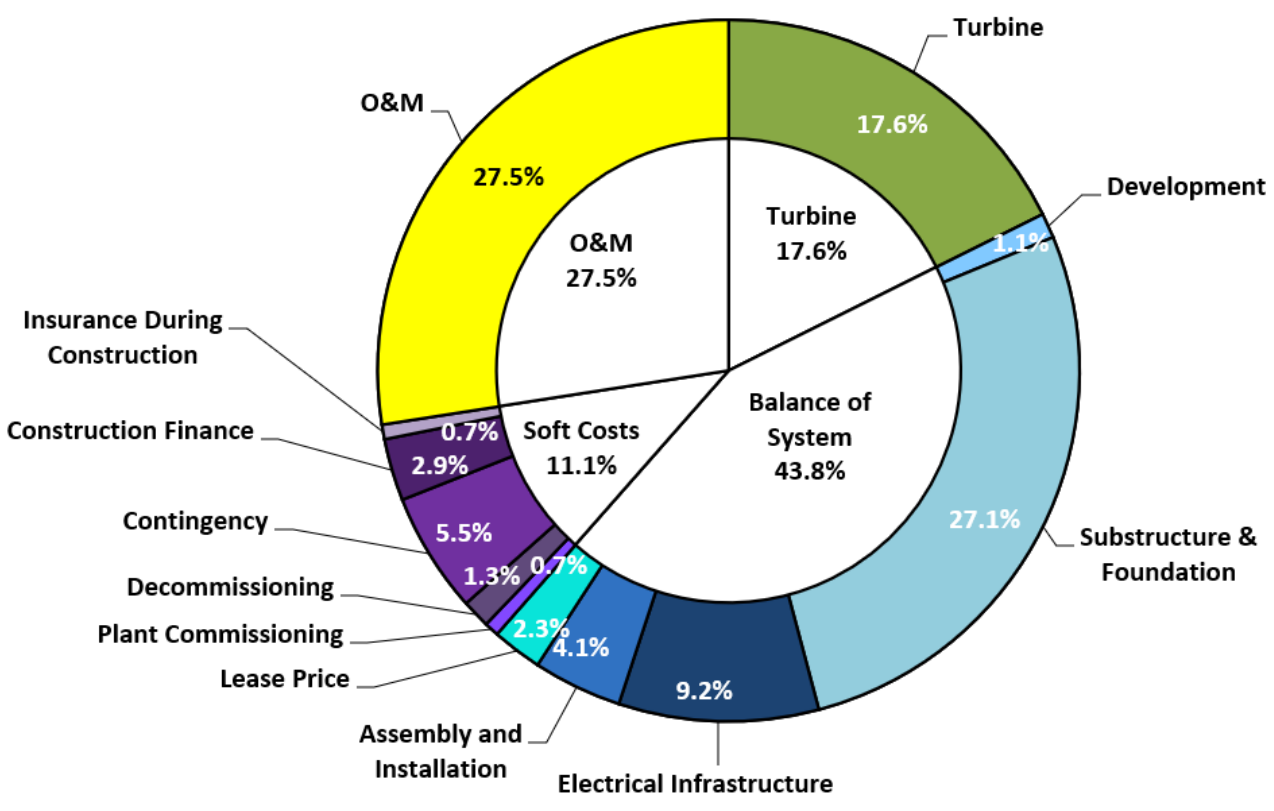

Figure ES3. Component-level LCOE contribution for the 2020 floating offshore wind reference project operating for 25 years
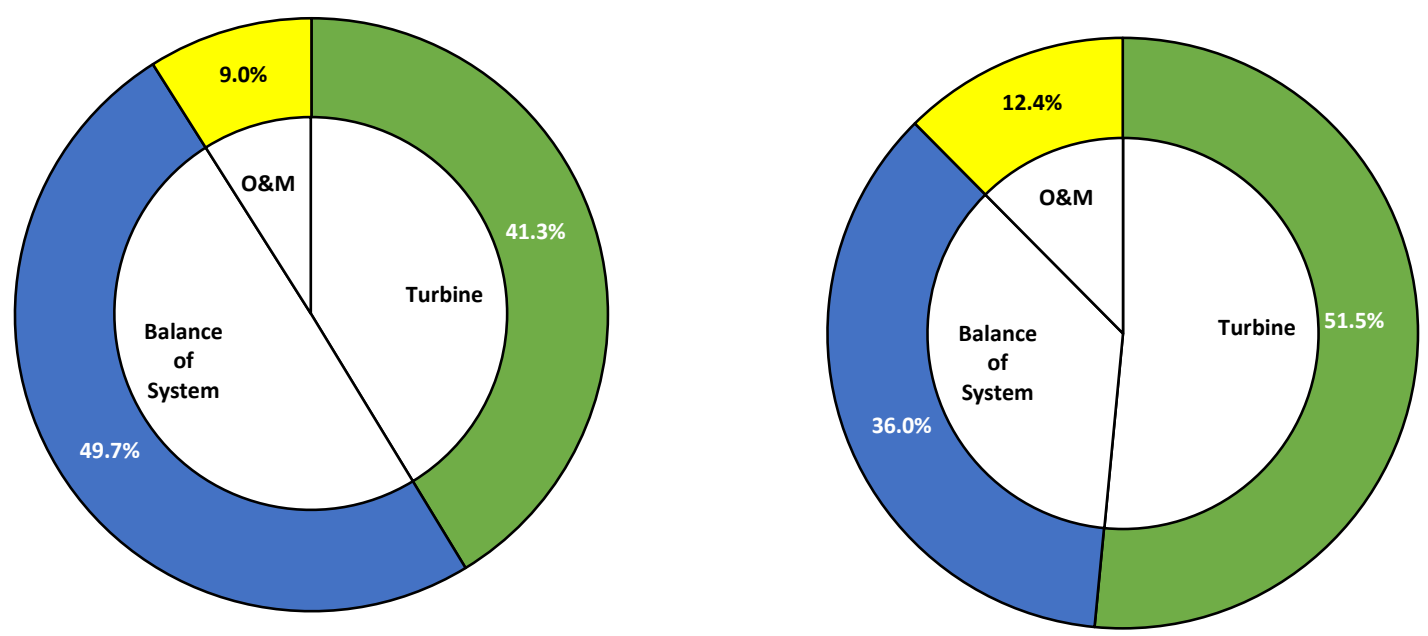

Figure ES4. Component-level LCOE contribution for the 2020 residential (left) and commercial (right) distributed wind reference projects operating for 25 years.

Note: Empirical data and cost model representation for residential and commercial distributed wind energy projects are limited; hence, detailed component-level LCOE contributions are not presented in this report.

Figure ES5, Figure ES6, and Figure ES7 illustrate the LCOE associated with the land-based and offshore reference power plants and provide a range of independent, single-variable sensitivities 
showing how these variables affect cost and performance. ${ }^{1}$ More specifically, these figures show the effect that CapEx, OpEx, net capacity factor, nominal discount rate, and project design life ${ }^{2}$ have on the LCOE for land-based, offshore, and distributed wind energy projects. Reference project values of $\$ 34 / \mathrm{MWh}$ for land-based wind, $\$ 77 / \mathrm{MWh}$ for fixed-bottom offshore wind, and $\$ 129 / \mathrm{MWh}$ for floating offshore wind rely on inputs summarized in Table ES1 through Table ES3 and are identified by the vertical white line in these figures. The figures also show sensitivity ranges pulled from representative industry data contained in the "Land-Based Wind Market Report: 2021 Edition" (Wiser and Bolinger 2021) for the LCOE inputs and the resulting calculated impacts on LCOE for land-based wind energy. The sensitivity ranges for fixed-bottom and floating offshore wind energy are informed by the "Offshore Wind Market Report: 2021 Edition" (Musial et al. 2021) and NREL's offshore wind database. The sensitivity ranges for residential and commercial distributed wind are presented in the "2019 Cost of Wind Energy Review" (Stehly et al. 2020) produced from representative industry data and analysis contained in the "2019 Distributed Wind Data Summary" (Orrell et al. 2020). The ranges for land-based and offshore wind LCOE inputs vary significantly (note the different axes in these figures). More detailed descriptions of the ranges and assumptions are included in Section 4.7 (land-based wind), and Section 5.7 (offshore wind).

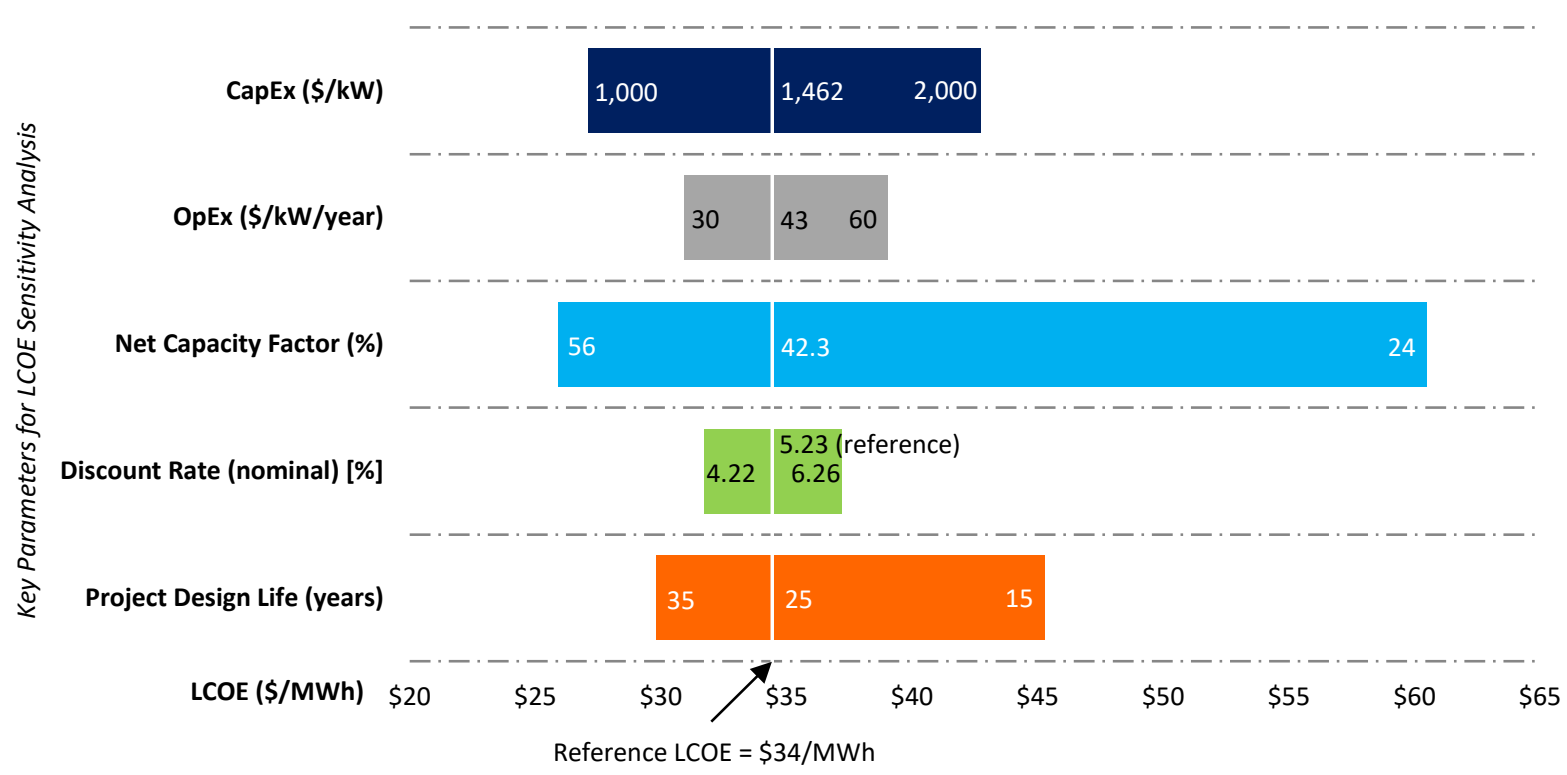

Figure ES5. Land-based wind power plant assumptions and ranges for key LCOE input parameters.

Note: The reference LCOE represents the estimated LCOE for the NREL reference project. Changes in LCOE for a single variable can be understood by moving to the left or right along a specific variable. Values on the $\mathrm{x}$-axis indicate how the LCOE will change as a given variable is altered, assuming that all others are constant. For example, as capacity factor decreases toward $24 \%$, the LCOE shown on the $x$ -

\footnotetext{
${ }^{1}$ Single-variable sensitivity results for residential and commercial distributed wind energy projects are omitted in this year's report because cost and performance estimates for the representative projects remain the same as reported in last year's report (Stehly et al. 2020).

${ }^{2}$ Project design life refers to the time in which the wind power plant is expected to operate (not referring to the wind turbine's design life for engineering or certification purposes).
} 
axis will increase accordingly to approximately $\$ 60 / \mathrm{MWh}$. Or, as the operational life for the reference project moves toward 35 years, the period in which a project achieves the requisite cash flow it needs to recover its initial CapEx and meet investors' internal rate of return threshold is assumed to be 35 years; therefore, the resulting LCOE decreases to nearly $\$ 30 / \mathrm{MWh}$.

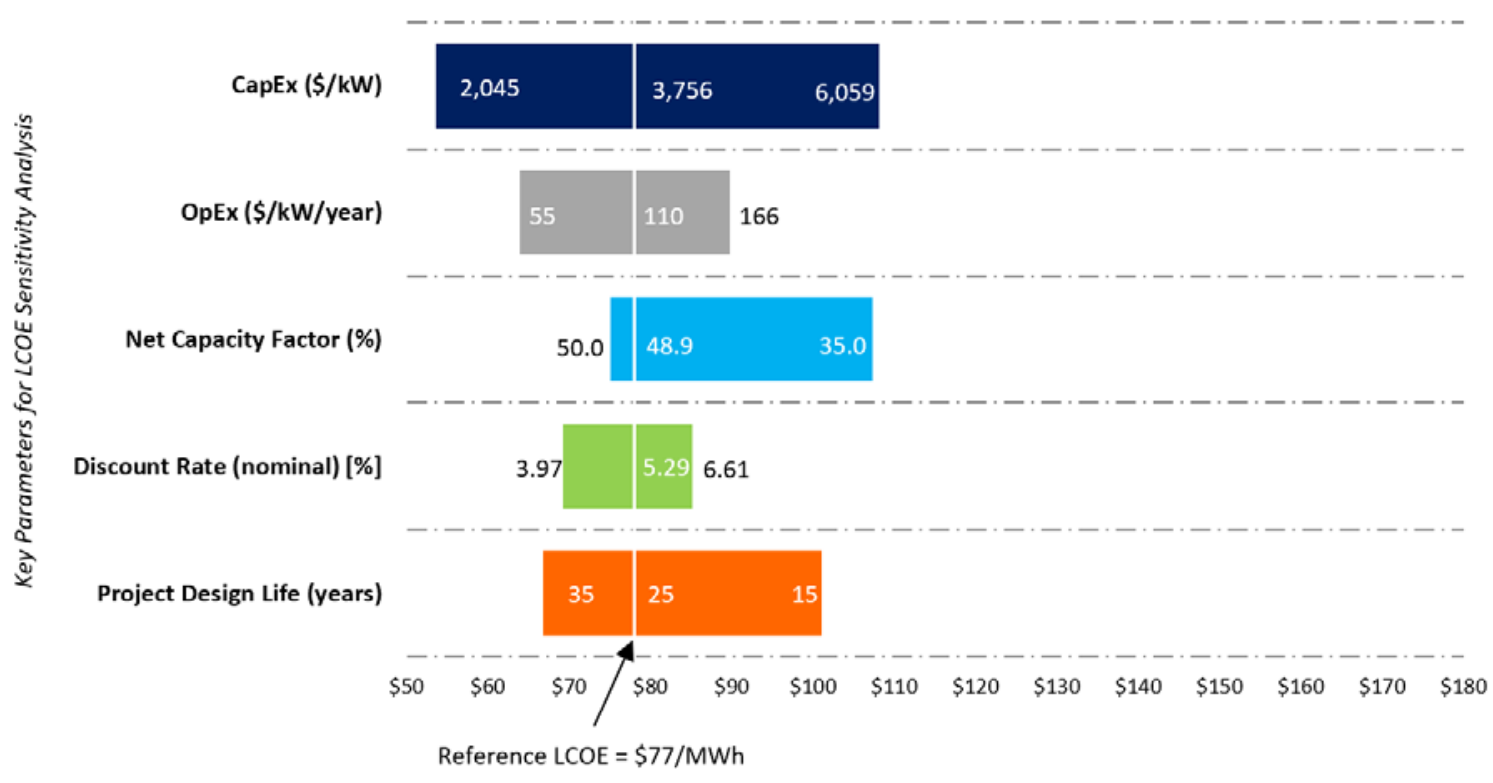

Figure ES6. Fixed-bottom offshore wind power plant assumption and ranges for key LCOE input parameters

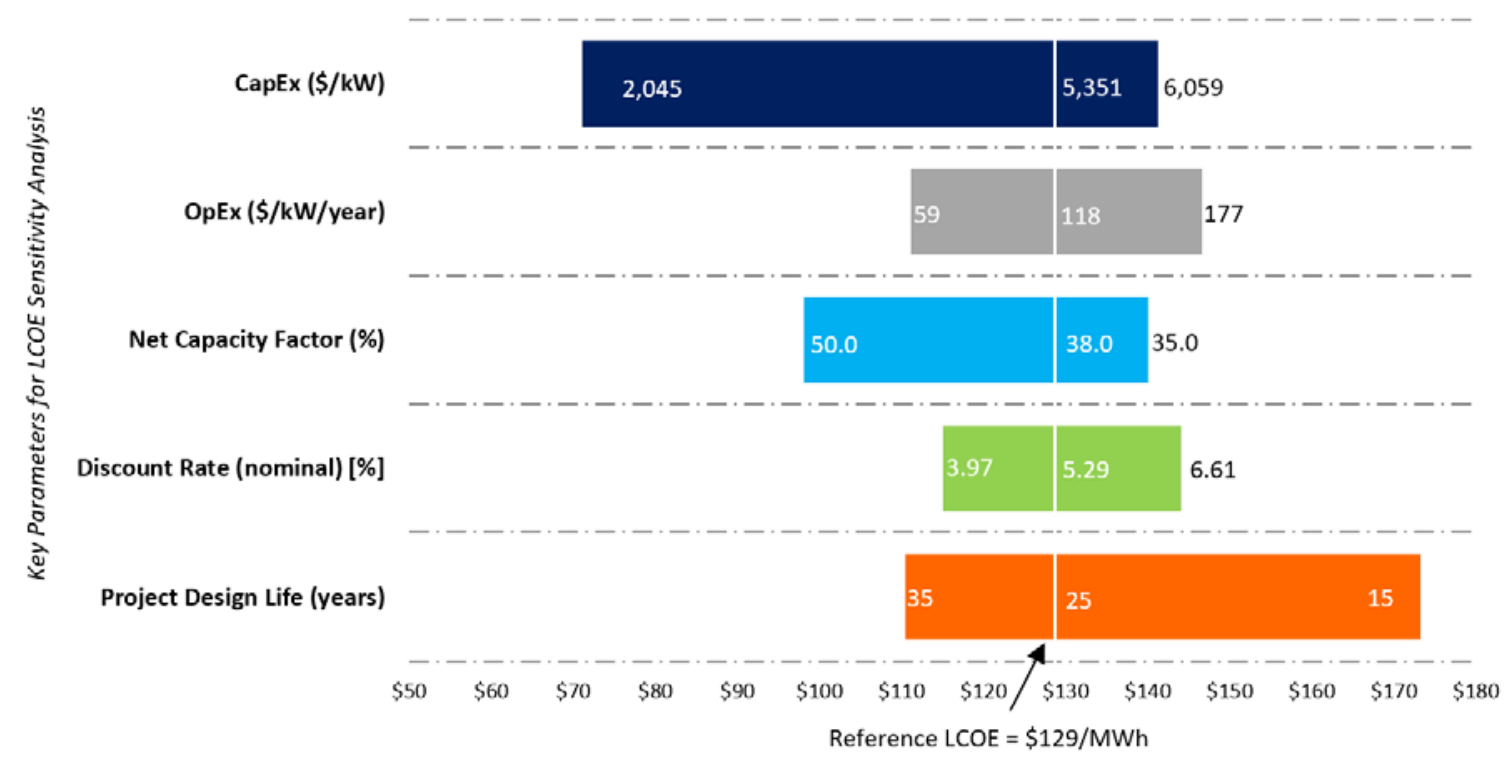

Figure ES7. Floating offshore wind power plant assumptions and ranges for key LCOE input parameters 
From the analysis detailed in this report, we derived the following key conclusions:

- Land-based wind power plant LCOE estimates continue to show a downward trend from the "2010 Cost of Wind Energy Review" (Tegen et al. 2012) to the 2020 review. The reference project LCOE for land-based installations was observed to be $\$ 34 / \mathrm{MWh},{ }^{3}$ with a range of land-based estimates from the single-variable sensitivity analysis covering $\$ 26-\$ 60 / \mathrm{MWh}^{4}$

- Offshore wind power plant LCOE estimates continue to decrease. The fixed-bottom reference project offshore estimate is $\$ 77 / \mathrm{MWh}$, and the floating substructure reference project estimate is $\$ 129 / \mathrm{MWh}$. These two reference projects give a single-variable sensitivity range of $\$ 54-\$ 173 / \mathrm{MWh}$. This range is primarily caused by the large variation in CapEx $(\$ 2,045-\$ 6,059 / \mathrm{kW})$, which is partially a function of water depth and distance from shore reported by project developers. More recent European and U.S. auction bids as of 2018 suggest that costs for offshore wind energy could fall further in the coming years. ${ }^{5}$

- The LCOE estimates for reference residential and commercial distributed wind energy projects are informed by 2019 market data from Orrell et al. (2020) because new project data were not available in 2020; however, assumptions to the financial inputs were updated for 2020. The residential and commercial reference distributed wind system LCOE are estimated at $\$ 151 / \mathrm{MWh}$ and $\$ 99 / \mathrm{MWh}$, respectively. Single-variable sensitivity analysis for the representative systems is presented in the "2019 Cost of Wind Energy Review" (Stehly et al. 2020).

\footnotetext{
${ }^{3}$ As the production tax credit ramps down and expires in 2021, it is likely that wind energy project weightedaverage cost of capital or discount rate will be reduced, as leverage increases and tax equity is replaced with cheaper debt.

${ }^{4} \mathrm{LCOE}$ estimates reflect a cost to a wind power plant developer and are not directly comparable with power purchase agreements that reflect the sale of electricity.

${ }^{5}$ Additional information on the recent European and U.S. auction bids can be found in the "2018 Offshore Wind Technologies Market Report" (Musial et al. 2019).
} 


\section{Table of Contents}

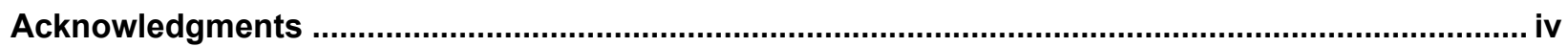

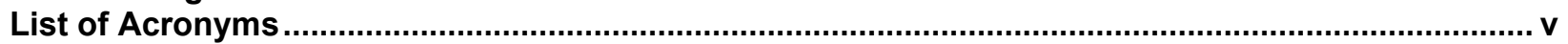

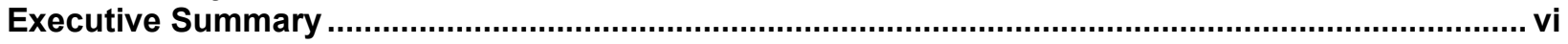

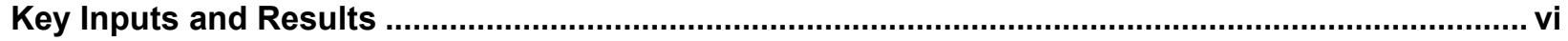

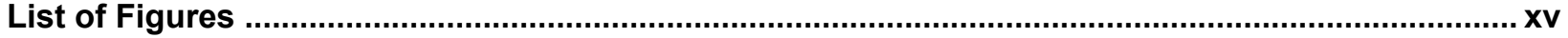

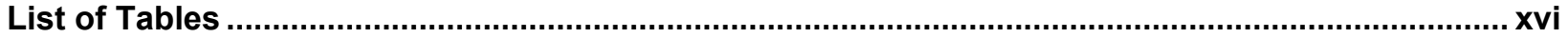

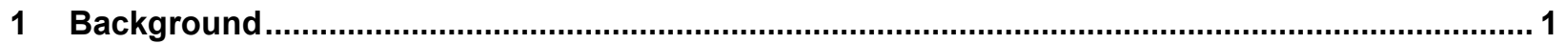

2 U.S. Department of Energy Goals and Reporting Requirements ............................................... 3

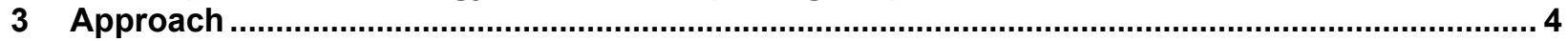

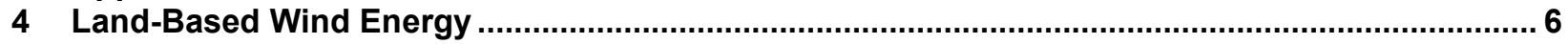

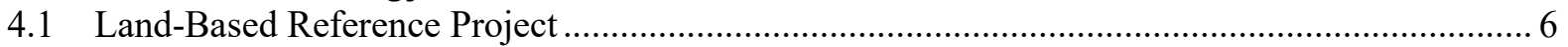

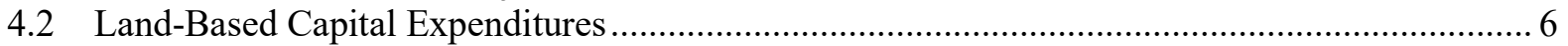

4.3 Land-Based Technology Characteristics and Annual Energy Production ................................. 9

4.4 Land-Based Operation and Maintenance Expenditures ........................................................... 11

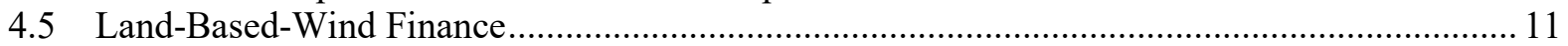

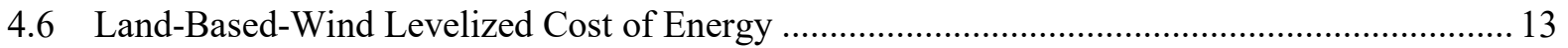

4.7 Land-Based-Wind Levelized Cost of Energy Sensitivities ..................................................... 15

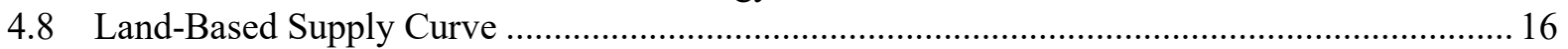

4.9 Land-Based-Wind Discussion of Results in Context of DOE Goals ..................................... 17

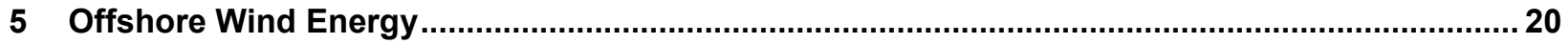

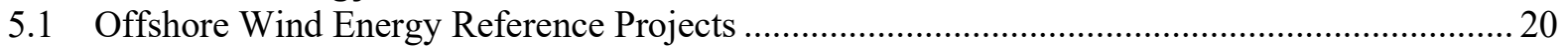

5.2 Offshore Wind Capital Expenditures .................................................................................. 21

5.3 Offshore Technology Characteristics and Annual Energy Production .................................... 25

5.4 Offshore Wind Operation and Maintenance Expenditures ….................................................. 27

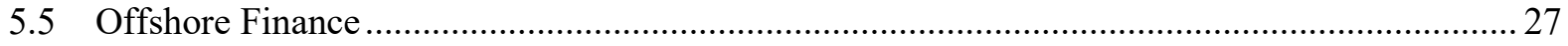

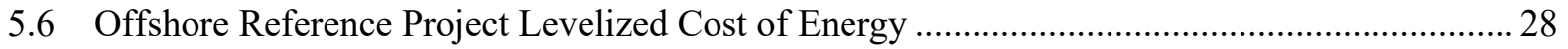

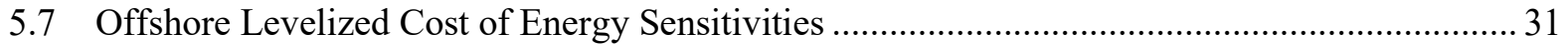

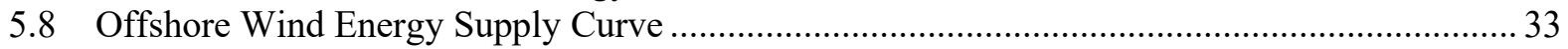

5.9 Offshore Discussion of Results in Context of DOE Goals...................................................... 34

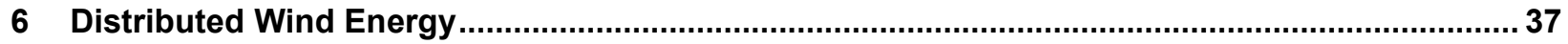

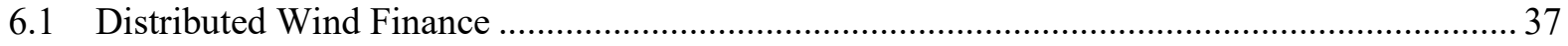

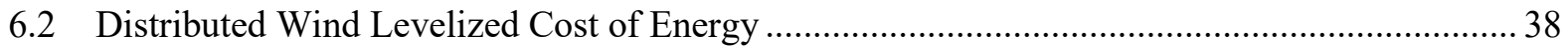

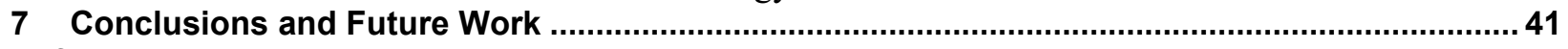

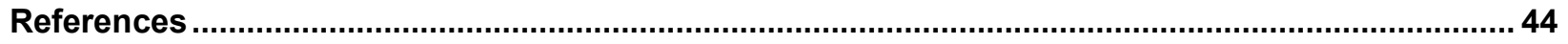

Appendix A. Offshore Wind Reference Site Development ......................................................... 49

Appendix B. Summary of Assumptions for 2020 Reference Projects .............................................. 51

\section{List of Figures}

Figure ES1. Component-level LCOE contribution for the 2020 land-based wind reference project operating for 25 years...

Figure ES2. Component-level LCOE contribution for the 2020 fixed-bottom offshore wind reference project operating for 25 years......................................................................................... $\mathrm{X}$

Figure ES3. Component-level LCOE contribution for the 2020 floating offshore wind reference project operating for 25 years ..............................................................................................

Figure ES4. Component-level LCOE contribution for the 2020 residential (left) and commercial (right) distributed wind reference projects operating for 25 years.

Figure ES5. Land-based wind power plant assumptions and ranges for key LCOE input parameters. .......................................................................................................................... Xii

Figure ES6. Fixed-bottom offshore wind power plant assumption and ranges for key LCOE input parameters ........................................................................................................................................ .

Figure ES7. Floating offshore wind power plant assumptions and ranges for key LCOE input 
parameters

Figure 1. CapEx for the land-based reference wind power plant project.

Figure 2. Component-level LCOE contribution for the 2020 land-based-wind reference project

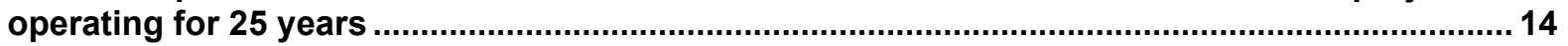

Figure 3. Component-level LCOE breakdown for the 2020 land-based-wind reference project ...... 15

Figure 4. Sensitivity of land-based-wind LCOE to key input parameters ........................................16

Figure 5. National land-based-wind resource supply curve with 2020 U.S. installed projects......... 17

Figure 6. Pathway to LCOE reduction in 2030 by LCOE parameter .................................................. 18

Figure 7. Land-based-wind GPRA cost trajectories for LCOE (in 2015 USD) ................................... 19

Figure 8. Capital expenditures for the fixed-bottom offshore wind reference project ...................... 22

Figure 9. Capital expenditures for the floating offshore wind reference project ................................ 23

Figure 10. Component-level LCOE contribution for the 2020 fixed-bottom offshore wind reference project operating for 25 years

Figure 11. Component-level cost breakdown for the 2020 fixed-bottom offshore wind reference project.

Figure 12. Component-level LCOE contribution for the 2020 floating offshore wind reference project operating for 25 years

Figure 13. Component-level cost breakdown for the 2020 floating offshore wind reference project

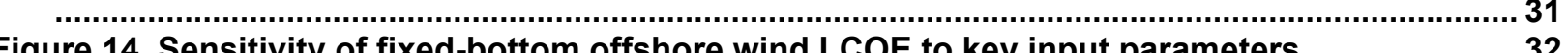

Figure 15. Sensitivity of floating offshore wind LCOE to key input parameters .................................32

Figure 16. National fixed-bottom and floating offshore wind supply curve ................................... 34

Figure 17. Fixed-bottom wind GPRA cost trajectories for LCOE.................................................. 35

Figure 18. Fixed-bottom cost reductions in GPRA cost trajectories for LCOE................................ 35

Figure 19. Floating cost reduction trajectories for LCOE ........................................................... 36

Figure 20. Component-level LCOE contribution for the 2020 residential (left) and commercial (right) distributed wind reference projects operating for 25 years .............................................40

\section{List of Tables}

Table ES1. Summary of the Land-Based Reference Project Using 2.8-megawatt (MW) Wind Turbines

Table ES2. Summary of the Fixed-Bottom Reference Project Using 8.0-MW Wind Turbines........... vii

Table ES3. Summary of the Floating Offshore Wind Reference Project Using 8.0-MW Turbines ... viii

Table ES4. Summary of the Residential Distributed Wind Reference Project Using a 20-kW Wind Turbine. viii

Table ES5. Summary of the Commercial Distributed Wind Reference Project Using a 100-kW Wind Turbine.

Table 1. Land-Based Wind GPRA Baseline and Target LCOE ......................................................... 3

Table 2. Offshore Fixed-Bottom Wind GPRA Baseline and Target LCOE......................................... 3

Table 3. Land-Based Reference Project Parameters..................................................................... 6

Table 4. Land-Based CapEx and LCOE Breakdown ................................................................... 8

Table 5. Reference Land-Based Wind Turbine Parameters .......................................................... 9

Table 6. Reference Land-Based-Wind Resource Assumptions ..................................................... 10

Table 7. Reference Land-Based-Wind Losses and Availability Assumptions................................... 10

Table 8. Reference Land-Based-Wind Power Plant AEP and Capacity Factor Summary ................ 10

Table 9. Land-Based-Wind Reference Project OpEx ......................................................................... 11

Table 10. Summary of Land-Based-Wind Reference Project Economic Evaluation Metrics ............ 13

Table 11. Summary of Inputs and Reference Project LCOE for 2020 Land-Based-Wind Installations

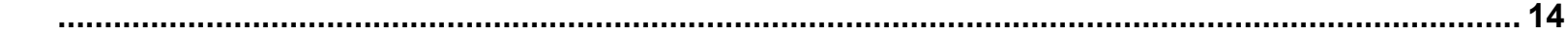

Table 12. Offshore Wind Reference Project Parameters (Fixed-Bottom and Floating Substructures)

Table 13. Fixed-Bottom Offshore CapEx and LCOE Breakdown

Table 13. Fixed-Bottom Offshore CapEx and LCOE Breakdown ...................................................2 23

Table 15. Reference Offshore Wind Turbine Parameter Input Assumptions.....................................25

Table 16. Reference Offshore Wind Resource Input Assumptions ................................................ 26 
Table 17. Reference Offshore Wind Total Losses ........................................................................ 26

Table 18. Reference Offshore Wind Net Annual Energy Production .............................................. 27

Table 19. Offshore Wind Reference Project OpEx.......................................................................... 27

Table 20. Summary of Offshore Reference Project Economic Evaluation Metrics ............................28

Table 21. Fixed-Bottom Offshore Wind LCOE and Reference Projects Cost Breakdown................ 29

Table 22. Floating Offshore Wind LCOE and Reference Projects Cost Breakdown .......................... 30

Table 23. Summary of Distributed Wind Reference Projects' Economic Evaluation Metrics........... 38

Table 24. Summary of Inputs and Reference Project LCOE for 2020 Residential Distributed Wind 39

Table 25. Summary of Inputs and Reference Project LCOE for 2020 Commercial Distributed Wind

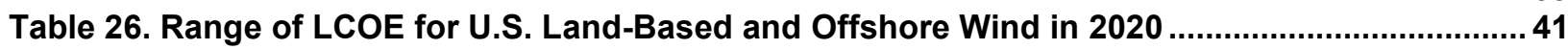

Table A1. Spatial Parameters for Regional Reference Sites .............................................................50

Table B1. Land-Based-Wind Reference Project Levelized Cost of Energy Assumptions.................51

Table B2. Fixed-Bottom Offshore Wind Reference Project Levelized Cost of Energy Assumptions

Table B3. Floating Offshore Wind Reference Project LCOE Assumptions ........................................... 55

Table B4. Residential Distributed Wind Reference Project LCOE Assumptions .............................57

Table B5. Commercial Distributed Wind Reference Project LCOE Assumptions............................. 58 


\section{Background}

This report estimates the levelized cost of energy (LCOE) for land-based and offshore wind energy projects in the United States. LCOE is a metric used to assess the cost of electricity generation and the total power-plant-level impact from technology design changes and can be used to compare costs of all types of generation. The specific LCOE method applied in this analysis is described in "A Manual for the Economic Evaluation of Energy Efficiency and Renewable Energy Technologies" (Short et al. 1995).

In addition, this report provides an update to the "2019 Cost of Wind Energy Review" (Stehly et al. 2020) and a look at the 2020 wind energy industry LCOE, wind turbine costs, financing, and market conditions. More specifically, this 2020 report includes:

- Estimated LCOE for a representative, land-based wind energy project installed in a moderate wind resource (i.e., International Electrotechnical Commission [IEC] wind class IIb [IEC 2020]) in the United States

- Estimated LCOE for representative offshore (fixed-bottom and floating) wind energy projects using National Renewable Energy Laboratory (NREL) models and databases of globally installed projects. The authors assessed, representative sites on the U.S. North Atlantic Coast (fixed bottom) and Pacific Coast (floating) using current lease and call information, nominations data from the Bureau of Ocean Energy Management, and various geospatial data sets

- LCOE estimates for representative residential and commercial distributed wind energy projects in the United States

- Sensitivity analyses showing the range of effects that basic LCOE variables could have on the cost of wind energy for land-based and offshore wind power plants

- Updates to the national supply curves for land-based and offshore wind energy based on geographically specific wind resource conditions paired with approximate wind turbine size characteristics

- Projected land-based and offshore wind cost trajectories from 2020 through 2030 used for U.S. Department of Energy (DOE) annual wind power LCOE reporting as required by the Government Performance and Results Act (GPRA).

This report addresses many assumptions and cost variables but does not include the full spectrum of drivers that affect wind energy prices. For example, it does not consider policy incentives (such as the production tax credit [PTC]), factors from underlying economic conditions (such as an economic recession), the cost of building long-haul interstate transmission, or potential grid integration costs (though offshore wind LCOE values include export cables and onshore spur lines). These important variables can have an impact by increasing or decreasing project costs or delaying projects. Nevertheless, their exclusion is consistent with past economic analyses conducted by NREL, as LCOE is not traditionally defined as a measure of all societal costs and benefits associated with power generation resources.

The standard Annual Technology Baseline (ATB) LCOE equation (NREL's Annual Technology Baseline and Standard Scenarios web page: atb.nrel.gov) can be simplified for each technology. 
For wind energy, the following equation is used to calculate LCOE:

$$
\mathrm{LCOE}=\frac{(\mathrm{CapEx} \times \mathrm{FCR})+0 \mathrm{pEx}}{\left(\mathrm{AEP}_{\text {net }} / 1,000\right)}
$$

where

LCOE $=$ levelized cost of energy (\$/megawatt-hour $[\mathrm{MWh}])$

$\mathrm{FCR}=$ fixed charge rate $(\%)$

CapEx $=$ capital expenditures $(\$ /$ kilowatt $[\mathrm{kW}])$

$\mathrm{AEP}_{\text {net }}=$ net average annual energy production $(\mathrm{MWh} /$ megawatt $[\mathrm{MW}] /$ year $[\mathrm{yr}])$

OpEx $=$ operational expenditures $(\$ / \mathrm{kW} / \mathrm{yr})$.

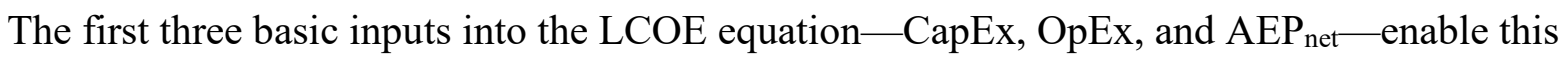
equation to capture system-level impacts from design changes (e.g., larger rotors or taller wind turbine towers). The fourth basic input-FCR - represents the amount of revenue required to pay the annual carrying charges as applied to the CapEx on that investment during the expected project economic life. All analysis and LCOE results are in 2020 U.S. dollars (USD) throughout this report unless otherwise noted. The upcoming sections define the approach to calculating the LCOE following the respective NREL system cost breakdown structures to organize data. This report also describes each component of the LCOE equation (such as CapEx, OpEx, AEP, and FCR), the market context, and a range of data for typical U.S. wind energy projects in 2020. 


\section{U.S. Department of Energy Goals and Reporting Requirements}

Every year, the DOE Wind Energy Technologies Office (WETO) reports the LCOE for landbased and fixed-bottom offshore wind energy to satisfy GPRA reporting requirements. The annually reported LCOE values are measured against current year and future LCOE targets set by WETO. The official GPRA levelized cost of energy end-point targets presented in this report were set in Fiscal Year (FY) 2016 for land-based wind energy and updated in FY 2019 for fixedbottom offshore wind energy. Updates to the LCOE targets are periodically implemented to keep performance measures current with developments in the market and reduce the impact of inflation on LCOE for land-based and offshore wind energy projects. The GPRA targets are based on trajectories for land-based and fixed-bottom offshore ${ }^{6}$ wind projects that span from the current year to FY 2030. A summary of the GPRA targets for land-based wind is shown in Table 1 and for offshore fixed-bottom wind in Table 2. It is required that each year the actual costs for land-based and fixed-bottom wind LCOE be reported against the GPRA targets. This report provides the cost data to DOE to meet the annual reporting requirement required by the GPRA. The assumptions and calculations for land-based and fixed-bottom offshore wind energy projects used in GPRA reporting are presented in more detail in Section 4.9 and Section 5.9, respectively.

Table 1. Land-Based Wind GPRA Baseline and Target LCOE

\begin{tabular}{|lc|c|}
\hline & $\begin{array}{c}\text { FY 2016 } \\
\text { (Baseline) }\end{array}$ & $\begin{array}{c}\text { FY 2030 } \\
\text { (Target) }\end{array}$ \\
\hline Land-based LCOE (2015\$/MWh) & 56 & 23 \\
\hline
\end{tabular}

Note: The GPRA baseline and target levelized cost of energy in Table 1 are reported in 2015 USD for land-based wind energy because WETO will report land-based wind values in 2015 USD.

Table 2. Offshore Fixed-Bottom Wind GPRA Baseline and Target LCOE

\begin{tabular}{|l|c|c|}
\hline & $\begin{array}{c}\text { FY 2019 } \\
\text { (Baseline) }\end{array}$ & $\begin{array}{c}\text { FY 2030 } \\
\text { (Target) }\end{array}$ \\
\hline Offshore fixed-bottom LCOE (2018\$/MWh) & 89 & 51 \\
\hline
\end{tabular}

Note: The GPRA baseline and target levelized cost of energy in Table 2 are reported in 2018 USD because WETO will report offshore fixed-bottom wind values in 2018 USD.

\footnotetext{
${ }^{6}$ As of Fiscal Year 2021, WETO does not report GPRA costs or targets for floating offshore wind or distributed wind energy technologies.
} 


\section{Approach}

This "2020 Cost of Wind Energy Review" applies a similar approach as the past cost of wind energy review reports (Tegen et al. 2012, 2013; Moné et al. 2015a, 2015b, 2017; Stehly et al. $2017,2018,2019,2020)$. The analysis uses several data sources and models to estimate the cost of wind energy. These models and data have been tested, documented, and verified within NREL, other national laboratories, universities, and industry to ensure that the methodology and tools are as accurate as possible. The land-based wind data use the annually released "LandBased Wind Market Report" authored by Lawrence Berkeley National Laboratory. Specific to the "2020 Cost of Wind Energy Review," the data come from Wiser and Bolinger (2021). The market data supporting the offshore wind energy analysis are limited to international projects and proposed U.S. projects reported in the "Offshore Wind Market Report: 2021 Edition" (Musial et al. 2021) and stored in NREL's offshore wind database ${ }^{7}$ of global offshore projects. Given the market and model data available, the general approach to estimating the levelized cost of wind energy includes:

- Evaluating market conditions and data for projects that have been installed in the United States each year to understand total land-based CapEx, annual energy production (AEP), annual OpEx for recently installed projects, and representative wind turbine technology. Representative turbine characteristics (i.e., rating, rotor diameter, and hub height) are taken as market averages of the turbines installed in 2020. Accordingly, LCOE estimates reflect average empirical conditions to the extent possible.

- Evaluating market conditions and data for projects that have been installed in Europe and Asia when considering offshore wind technology each year to understand total CapEx, OpEx, and representative turbine technology. AEP and balance-of-system (BOS) costs are modeled using the specified U.S. North Atlantic site conditions. The primary sources for these data are NREL's offshore wind database and the "Offshore Wind Market Report: 2021 Edition” (Musial et al. 2021).

- Supplementing available market data with modeled data based on a representative or reference project that reflects technology and project parameters for a given year. Analysts used the following suite of NREL models to complete the LCOE analysis:

○ The 2015 Cost and Scaling Model ${ }^{8}$ (CSM). We used the CSM to estimate utilityscale land-based wind turbine costs by applying scaling relationships at the component level (e.g., blade, hub, generator, and tower) that reflect the componentspecific and often nonlinear relationships between size and cost.

- The Land-based Balance of System Systems Engineering (LandBOSSE) model. We used the LandBOSSE model to estimate all BOS components of the utility-scale ${ }^{9}$ and distributed wind (residential and commercial) reference projects. This model is based on a bottom-up assessment of inputs and outputs associated with each BOS operation and is supplemented by top-down estimate of costs from industry. Additional details on the model can be found in Eberle et al. (2019). Prior versions of

\footnotetext{
${ }^{7}$ NREL's offshore wind database is used as an internal reference and is not publicly available.

${ }^{8}$ NREL's 2015 Cost and Scaling Model is used as an internal reference and is not publicly available.

${ }^{9}$ This is the first year LandBOSSE was used to estimate BOS costs for utility-scale land-based wind energy; hence, BOS cost differences may be observed from prior versions of this report.
} 
this report used a former BOS cost model to estimate land-based utility scale BOS costs that utilizes scaling relationships based on historical empirical wind industry data. Compared to the legacy model, LandBOSSE is a more sophisticated processbased model comprising more recent cost and wind turbine characteristic data that are expected to provide more representative BOS component cost estimates.

○ The NREL Offshore Wind Cost Model (Beiter et al. 2016). Also referred to as the Offshore Wind Regional Cost Analyzer (ORCA), we used ORCA to estimate the soft costs in CapEx as well as OpEx. This report represents the first time that the Offshore Renewables Balance-of-System and Installation Tool (ORBIT) has been used for calculating BOS costs in lieu of ORCA.

- ORBIT. We used ORBIT to estimate the BOS components of the utility-scale ${ }^{10}$ fixed-bottom and floating offshore wind reference projects. ORBIT is NREL's Python-based, open-source, bottom-up offshore wind BOS cost model and is capable of analyzing the installation phases of offshore wind projects to estimate installation times and costs. ORBIT offers greater transparency than ORCA when modeling the physical and spatial relationships of BOS costs for offshore wind energy. Core cost relationships represented in ORBIT have been vetted with industry partners, offering a higher degree of confidence than ORCA for capturing recent offshore BOS cost trends on a site-specific level.

○ The System Advisor Model (https://sam.nrel.gov/). We used the System Advisor Model to develop an idealized power curve ${ }^{11}$ and estimate net energy production for land-based wind energy on turbine rated capacity, rotor diameter, hub height, and a representative wind resource.

- Combining the market and modeled data described earlier to estimate the primary elements necessary to calculate LCOE (i.e., CapEx, OpEx, AEP, and FCR) and provide details about wind technology costs and performance that are aligned with market data but reported at a more detailed resolution. Unless specifically stated, all data and analysis used in this report are in 2020 USD, considering changes resulting from inflation from previous reports.

\footnotetext{
${ }^{10}$ This is the first year ORBIT was used to estimate BOS costs for utility-scale offshore wind in the "2020 Cost of Wind Energy Review"; hence, BOS cost differences may be observed from prior versions of this report. Code and documentation are available on GitHub at https://github.com/WISDEM/ORBIT, and the model methodology is described in Nunemaker et al. (2020).

11 The resulting power curve is available on GitHub through an NREL-hosted repository of tabular data and documentation of wind turbine power curves at https://github.com/NREL/turbine-models.
} 


\section{Land-Based Wind Energy}

The wind turbine characteristics used in the land-based wind reference project were derived from the "Land-Based Wind Market Report: 2021 Edition" (Wiser and Bolinger 2021). Reference project wind turbine and component costs are based on a hypothetical wind turbine that comprises the average parameters - nameplate capacity, rotor diameter, and hub height - of turbines that were installed in the United States in 2020. This type of turbine rests on a standard spread-foot foundation design and incorporates a three-stage planetary/helical gearbox feeding a high-speed asynchronous generator. The 2020 reference project wind regime is intended to reflect an International Electrotechnical Commission (IEC) class IIb (IEC 2020). This wind resource site is consistent with prior versions of this report and a typical power plant size of 200 MW.

\subsection{Land-Based Reference Project}

The land-based reference project is intended to represent a wind site found in the interior region of the United States. The wind power plant specific to this analysis comprises 73 wind turbines that are each rated at $2.8 \mathrm{MW}$ (based on the average wind turbine size installed in the United States in 2020), equating to a capacity of $200 \mathrm{MW}$. These reference project parameters are summarized in Table 3, with further detail on the turbine parameters provided in Table 5. The wind power plant layout is roughly placed in a grid layout at an elevation around 450 meters $(\mathrm{m})$ above sea level - the reference elevation is used for calculating the wind plant's AEP. The wind power plant is assumed to be operating for 25 years with no catastrophic operation and maintenance $(\mathrm{O} \& \mathrm{M})$ events.

Table 3. Land-Based Reference Project Parameters

\begin{tabular}{|lc|}
\hline \multicolumn{2}{|c|}{ Project Parameters } \\
\hline Turbine rated power (MW) & 2.8 \\
\hline Number of wind turbines & 73 \\
\hline Wind power plant capacity (MW) & 200 \\
\hline Elevation above sea level (m) & 450 \\
\hline Project design life (years) & 25 \\
\hline
\end{tabular}

Note: Project design life refers to the time in which the wind power plant is expected to operate (not referring to the turbine's design life for engineering or certification purposes).

\subsection{Land-Based Capital Expenditures}

The weighted-average CapEx data are published annually by DOE (Wiser and Bolinger 2021). We used the NREL 2015 CSM to determine the component cost breakdown given the total CapEx cost estimates reported by Wiser and Bolinger (2021). The NREL 2015 CSM uses curve fits from commercial wind turbine component design and cost data while providing the ability to adjust inputs, such as overhead, profit, and transportation. Figure 1 illustrates the breakdown of CapEx for the NREL land-based reference wind project. In the figure, the CapEx component percentages highlighted in shades of green capture the turbine capital cost, the percentages highlighted in blue capture the BOS share of capital costs, and the components highlighted in purple capture the financial CapEx. For information on the assumptions and inclusions of the individual components, see the "2013 Cost of Wind Energy Review" (Moné et al. 2015a). Some 
costs, such as transportation, are rolled up into higher categories (such as nacelle and blades), as the specific data are difficult to obtain based on a theoretical reference site.

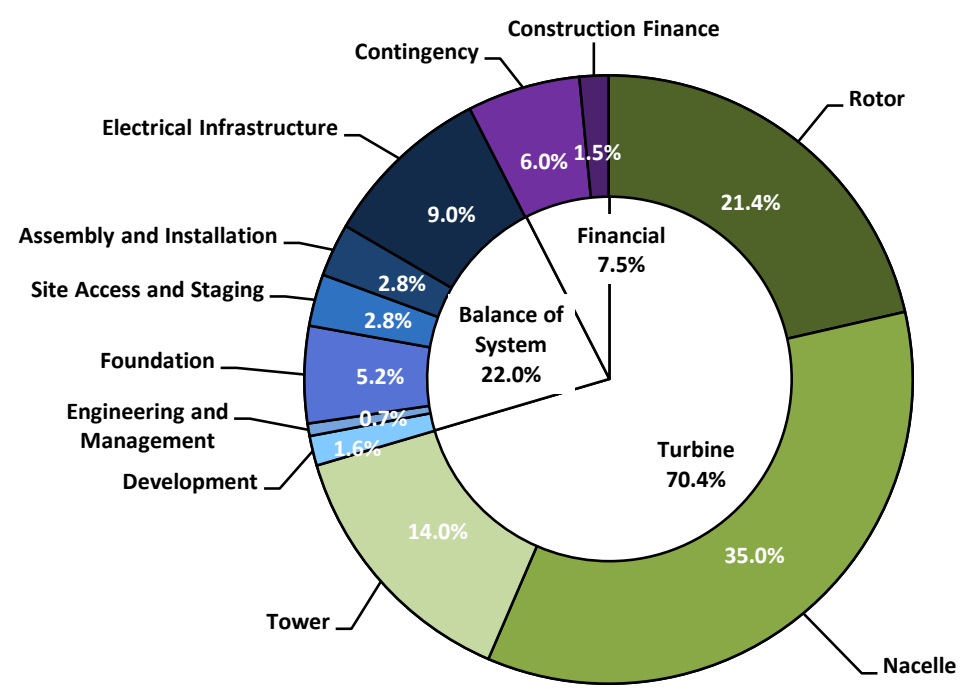

Figure 1. CapEx for the land-based reference wind power plant project

Table 4 summarizes the costs for the reference project's individual components (including their contribution to LCOE). More details on the representative wind power plant's energy production and financial assumptions used to calculate LCOE are provided in Section 4.3 and Section 4.5, respectively. 
Table 4. Land-Based CapEx and LCOE Breakdown

\begin{tabular}{|c|c|c|}
\hline & $\begin{array}{c}\text { 2.8-MW Land-Based } \\
\text { Wind Turbine } \\
\text { (\$/kilowatt [kW]) }\end{array}$ & $\begin{array}{c}\text { 2.8-MW Land-Based } \\
\text { Wind Turbine } \\
\text { (\$/MWh) }\end{array}$ \\
\hline Rotor module & 311 & 4.8 \\
\hline Blades & 201 & 3.1 \\
\hline Pitch assembly & 62 & 1.0 \\
\hline Hub assembly & 47 & 0.7 \\
\hline Nacelle module & 508 & 7.9 \\
\hline Nacelle structural assembly & 102 & 1.6 \\
\hline Drivetrain assembly & 203 & 3.2 \\
\hline Nacelle electrical assembly & 164 & 2.6 \\
\hline Yaw assembly & 38 & 0.6 \\
\hline \multirow[t]{2}{*}{ Tower module } & 203 & 3.2 \\
\hline & 1,021 & 15.9 \\
\hline Development & 23 & 0.4 \\
\hline Engineering and project management & 10 & 0.2 \\
\hline Foundation & 75 & 1.2 \\
\hline Site access and staging & 40 & 0.6 \\
\hline Assembly and installation & 41 & 0.6 \\
\hline Electrical infrastructure & 131 & 2.0 \\
\hline Balance of system & 319 & 5.0 \\
\hline Construction financing cost & 34 & 0.5 \\
\hline \multirow[t]{2}{*}{ Contingency fund } & 88 & 1.4 \\
\hline & 122 & 1.9 \\
\hline Total capital expenditures & 1,462 & 22.8 \\
\hline
\end{tabular}

Because of CapEx variability among projects, we established estimates for the turbine component costs using the NREL 2015 CSM. In this year's report, we estimate BOS costs using the recently developed LandBOSSE model (Eberle et al. 2019), as opposed to NREL's LandBased-Wind BOS model used in the prior version of this report. Construction financing was estimated assuming a 3-year construction duration and distributing the capital and interest over the 3 years. We estimated the project contingency at $6 \%$ of CapEx, which is consistent with industry reporting. Total installed project CapEx for U.S. projects in 2020 averaged $\$ 1,462 / \mathrm{kW}$ (Wiser and Bolinger 2021) and has remained relatively stable over the last 3 years. 


\subsection{Land-Based Technology Characteristics and Annual Energy Production}

\subsubsection{Wind Turbine Parameters}

For this report, the turbine parameters are specific to the wind turbine and independent of the wind resource characteristics. These parameters include not only turbine size (such as rated power, rotor diameter, and hub height), but also turbine operating characteristics (such as coefficient of power, maximum tip speed, maximum tip-speed ratio, and drivetrain design). Because the three-stage planetary/helical gearbox with a high-speed asynchronous generatorstyle drivetrain topology dominates the U.S. market, we selected this type of drivetrain for the baseline wind turbines used in this analysis. The power curve for the 2.8-MW land-based wind turbine is derived from NREL's System Advisor Model. A summary of the turbine parameters is shown in Table 5. For specific approaches regarding additional turbine parameters (e.g., power curves), see the "2010 Cost of Wind Energy Review" (Tegen et al. 2012).

Table 5. Reference Land-Based Wind Turbine Parameters

\begin{tabular}{|lc|}
\hline & Turbine Parameters \\
\hline Turbine rated power $(\mathrm{MW})$ & 2.8 \\
\hline Turbine rotor diameter $(\mathrm{m})$ & 125 \\
\hline Turbine hub height $(\mathrm{m})$ & 90 \\
\hline Maximum rotor tip speed (meters per second $[\mathrm{m} / \mathrm{s}])$ & 80 \\
\hline Tip-speed ratio at maximum coefficient of power $\left(\mathrm{C}_{\mathrm{p}}\right)$ & 8 \\
\hline Drivetrain design & Geared \\
\hline Cut-in wind speed $(\mathrm{m} / \mathrm{s})$ & 3 \\
\hline Cut-out wind speed $(\mathrm{m} / \mathrm{s})$ & 25 \\
\hline Maximum coefficient of power & 0.47 \\
\hline
\end{tabular}

\subsubsection{Wind Resource}

The average wind speed varies from project to project across the United States. The annual average wind speed chosen for the reference project analysis, which is consistent with prior reports, is 7.25 meters per second $(\mathrm{m} / \mathrm{s})$ at 50 meters $(\mathrm{m})$ above ground level $(7.89 \mathrm{~m} / \mathrm{s}$ at a hub height of $90 \mathrm{~m}$ ). This wind speed is intended to be generally indicative of the wind regime for projects installed in moderate-quality sites (i.e., IEC wind class IIb). We applied an elevation of $450 \mathrm{~m}$ above sea level based on this concept of using a representative site that would have a similar altitude to a project located within the interior of the country. The representative elevation defines the air density used for calculating the project AEP. A summary of the wind resource assumptions for the 2020 representative site is included in Table 6. 
Table 6. Reference Land-Based-Wind Resource Assumptions

\begin{tabular}{|lc|}
\hline \multicolumn{2}{|c|}{ Wind Resource Characteristics } \\
\hline Annual average wind speed at a 50-m height $(\mathrm{m} / \mathrm{s})$ & 7.25 \\
\hline Annual average wind speed at a $90-\mathrm{m}$ hub height $(\mathrm{m} / \mathrm{s})$ & 7.89 \\
\hline Weibull k & 2.0 \\
\hline Shear exponent & 0.143 \\
\hline Turbine elevation (meters above sea level) & 450 \\
\hline
\end{tabular}

\subsubsection{Losses and Availability}

Although some losses can be affected by turbine design or wind resource characteristics, they are treated as independent of any other input in this simplified analysis. Types of losses accounted for here include array wake losses, electric collection system and transmission losses (from the substation to the point of interconnection), and blade soiling losses, totaling $15 \%$. A wind power plant availability of $98 \%$ is assumed, indicating the plant is ready to produce power $98 \%$ of the time that the wind speed falls within the operational range (i.e., between the wind turbine's cut-in and cut-out wind speeds). Wind power plant availability accounts for any unplanned downtime the plant may experience, such as unplanned maintenance activities. The net average AEP is then calculated by applying all losses and availability to the gross AEP. Table 7 shows the estimated losses and availability for the land-based reference wind power plant.

Table 7. Reference Land-Based-Wind Losses and Availability Assumptions

\begin{tabular}{|lc|}
\hline \multicolumn{2}{|c|}{ Losses } \\
\hline Losses (i.e., array, energy conversion, and line) & $15 \%$ \\
\hline Availability & $98 \%$ \\
\hline
\end{tabular}

\subsubsection{Annual Energy Production}

We computed the AEP for this analysis using the System Advisor Model. The model uses an idealized power curve based on the wind turbine configuration and computes annual energy capture for a wind project that is specified by the wind resource and the wind power plant's assumed losses and availability. The result of these calculations yields a net energy capture of $3,707 \mathrm{MWh} / \mathrm{MW} / \mathrm{year}(\mathrm{yr})$, which corresponds to a $42.3 \%$ net capacity factor assuming 8,760 hours in a year. For reference, the average capacity factor reported by Wiser and Bolinger (2021) among recently built projects was over $40 \%$. The net energy capture and net capacity factor for the reference wind plant are shown in Table 8.

Table 8. Reference Land-Based-Wind Power Plant AEP and Capacity Factor Summary

\begin{tabular}{|lc|}
\hline \multicolumn{2}{|c|}{ AEP and Capacity Factors } \\
\hline Net energy capture (MWh/MW/year [yr]) & $7.25 \mathrm{~m} / \mathrm{s}$ at $50 \mathrm{~m}$ \\
\hline Net capacity factor (\%) & 3,703 \\
\hline
\end{tabular}




\subsection{Land-Based Operation and Maintenance Expenditures}

OpEx costs are generally organized into two categories: 1) fixed O\&M costs (e.g., scheduled plant maintenance or land lease costs) and 2) variable O\&M costs (e.g., unscheduled plant maintenance). For simplicity, annual OpEx can be converted to a single term and expressed as either dollars per kilowatt per year $(\$ / \mathrm{kW} / \mathrm{yr})$ or dollars per megawatt-hour $(\$ / \mathrm{MWh})$. This analysis uses the dollars-per-kilowatt-per-year convention. O\&M market data are not widely available; therefore, the recent U.S. wind industry survey, "Assessing wind power operating costs in the United States: Results from a survey of wind industry experts" (Wiser et al. 2019) is used to inform the O\&M cost estimates for the representative wind power plant. For recently installed projects, entering commercial operations from 2015 through 2018, the survey results anticipate an average range of O\&M costs between $\$ 33$ and $\$ 59 / \mathrm{kW} / \mathrm{yr}$. The average across respondents was $\sim \$ 43 / \mathrm{kW} / \mathrm{yr}$ and is assumed to be the all-in levelized OpEx for the representative project. ${ }^{12}$ The annual O\&M cost from the expert survey and the calculated O\&M cost on an energy basis for the representative wind power plant is shown in Table 9.

Table 9. Land-Based-Wind Reference Project OpEx

\begin{tabular}{|c|c|c|}
\hline & $\begin{array}{l}\text { 2.8-MW Land-Based } \\
\text { Wind Turbine }\end{array}$ & $\begin{array}{l}\text { 2.8-MW Land-Based } \\
\text { Wind Turbine }\end{array}$ \\
\hline & $(\$ / k W / y r)$ & \$/MWh \\
\hline OpEx & 43 & 11.5 \\
\hline
\end{tabular}

\subsection{Land-Based-Wind Finance}

This section describes the financing assumptions for the report's representative land-based-wind reference project in the United States in 2020. It is important to distinguish between financing assumptions and financial costs. Financial costs, which are part of CapEx according to the system cost breakdown structure, include items such as insurance, contingency, and reserve accounts. Financing assumptions, on the other hand, refer to the cost of interest and other carrying charges, corporate taxes, and depreciation (represented by the FCR in this report), applied to the total CapEx. To capture the financing structure and costs, we use a fixed charge rate, detailed in Section 4.5.2, for the LCOE equation.

\subsubsection{Discount Rate}

Typically, various financial terms, such as the cost of debt or equity, are captured in the discount rate, which is in turn used to estimate the cost of energy. For this analysis, we calculate the discount rate as the after-tax weighted-average cost of capital (WACC), and we presume that the reported yields for equity are after-tax yields and can be used directly in the WACC calculation. The cost of debt (as a value) is also reported, but because interest on debt is tax deductible, we use an effective corporate marginal tax rate to determine an after-tax cost of debt for the discount rate calculation. The cost of capital data collected by Lawrence Berkeley National Laboratory (Wiser and Bolinger 2021) gives a basis for WACC assumptions for the representative wind project in 2020 and results in a nominal WACC of 5.23\%. This WACC was derived assuming a debt fraction of $47.9 \%$, nominal debt interest rate of $2.61 \%$, nominal return on equity of $8.25 \%$,

\footnotetext{
${ }^{12}$ Given the scarcity and varying quality of the data, OpEx may vary substantially among projects, and the data included here may not fully represent the challenges that OpEx present to the wind energy industry.
} 
and a $25.7 \%$ tax rate. ${ }^{13}$ Each actual project, however, has a unique risk profile, financing terms, and ownership structure. For this reason, a single WACC representing the entire fleet of 2020 wind energy installations should be viewed cautiously and used to illustrate general market trends and conditions only.

In financial modeling, corporate tax rates are often presented as a composite, or effective, tax rate. This rate is calculated from a blend of the highest marginal corporate tax rate of $21 \%$ and an approximate typical state corporate tax rate. Because state taxes are normally deductible expenses on federal tax returns, the blended rate is represented as $25.7 \%$, as reported in NREL's ATB. Wind projects are often organized as disregarded entities for tax purposes (i.e., no taxes are paid by the project entity) and taxes are paid further up the organizational structure at some corporate level.

The inflation rate has been set to $2.5 \%$. This rate aligns with the inflation rate provided in NREL's ATB. Discount rates are initially calculated in nominal after-tax USD, and an estimate of inflation is used to calculate a discount rate in real after-tax USD.

Although the PTC is a critical component for wind energy projects installed in 2020, it is expected to phase out in future years. ${ }^{14}$ Research shows that one likely outcome of the termination of the PTC is increased project leverage, which will reduce the higher-cost taxequity portion of project finance. This shift of capital structure is expected to partially offset the impact of the lack of PTC (Bolinger 2014). There continues to be active discussions among lawmakers surrounding possible additional PTC extensions, which could have a significant impact on the project finance market in years to come (Wiser and Bolinger 2021).

\subsubsection{Economic Evaluation Metrics}

In the economic evaluation of wind energy investments there are two important metrics: the capital recovery factor (CRF) and FCR. The FCR represents the amount of annual revenue required to pay the carrying charge ${ }^{15}$ as applied to the CapEx on that investment during the expected project economic life. ${ }^{16}$ The FCR is based on the capital recovery factor but also reflects corporate income taxes and depreciation. The ATB methodology is used to calculate the FCR.

The CRF is defined as "the uniform periodic payment, as a fraction of the original investment cost that will fully repay a loan including all interest, over the term of the loan" (Short et al. 1995). The CRF can be thought of as the recurring fixed payment over the life of a loan common to most types of mortgages. Note, the CRF ignores the impact of corporate income taxes, thus it applies to a no-tax investment scenario, such as from a government investment.

\footnotetext{
${ }^{13}$ Because these data are derived from installed wind energy projects in 2020, they include the impact of the PTC on the debt ratio even though the LCOE estimates do not include the PTC.

14 "In December 2020, Congress extended the PTC for yet another year (i.e., projects must start construction by the end of 2021) at the $60 \%$ level, while in June 2021, the IRS extended the safe-harbor window yet again, to six years for projects that started construction in 2016-2019 and to five years for projects that started construction in 2020" (Wiser and Bolinger 2021).

${ }^{15}$ Carrying charges include the return on debt, return on equity, taxes, and depreciation.

${ }^{16}$ The FCR does not allow for detailed analysis of specific financing structures; however, these structures can be represented through the use of a WACC as the discount rate input.
} 
A reasonable assumption for land-based wind energy projects is that $95 \%$ of the project capital cost is eligible for 5-year (Modified Accelerated Cost Recovery System [MACRS]) depreciation, and the balance of the project capital cost is eligible for 15-year MACRS. In this work, the MACRS assumption is further simplified by assuming that $100 \%$ of the wind project cost basis is eligible for 5-year MACRS.

Table 10 presents the estimated WACC, CRF, and FCR in nominal and real terms using the after-tax WACC discount rate of $6.32 \%$ and $3.72 \%$, respectively, a project design lifetime of 25 years, and a net present value depreciation factor of $84.6 \%$ (assuming a 5-year MACRS depreciation schedule). The nominal and real CRF are estimated at $8.06 \%$ and $6.21 \%$, respectively. The nominal FCR is estimated at $8.49 \%$ and the real FCR is estimated at $6.55 \%$. As noted in Short et al. (1995), comparisons of two or more capital investments should be on a consistent tax treatment basis (i.e., both investments using a before-tax method or an after-tax method).

Table 10. Summary of Land-Based-Wind Reference Project Economic Evaluation Metrics

\begin{tabular}{|lcc|}
\hline Weighted-average cost of capital (\%) & Nominal & Real \\
\hline Capital recovery factor (\%) & $7.26 \%$ & $2.66 \%$ \\
\hline Fixed charge rate (\%) & $7.59 \%$ & $5.53 \%$ \\
\hline
\end{tabular}

\subsection{Land-Based-Wind Levelized Cost of Energy}

The levelized cost of energy for the 2020 representative land-based wind power plant is calculated using the formulation presented in NREL's ATB and the representative wind turbine technology parameters, site conditions, wind resource, and cost estimates (i.e., CapEx, FCR, OpEx, and AEP). The LCOE value for the 2020 representative plant is estimated at \$34/MWh. Table 11 summarizes the costs for the primary components on a per-kilowatt and per-megawatthour basis. The graphic in Figure 2 illustrates the LCOE breakdown for the primary components of the representative wind power plant, whereas Figure 3 depicts the absolute LCOE values for each of the components. 
Table 11. Summary of Inputs and Reference Project LCOE for 2020 Land-Based-Wind Installations

\begin{tabular}{|c|c|c|}
\hline & $\begin{array}{l}\text { 2.8-MW Land-Based } \\
\text { Wind Turbine } \\
(\$ / \mathbf{k W})\end{array}$ & $\begin{array}{c}\text { 2.8-MW Land-Based } \\
\text { Wind Turbine } \\
\text { (\$/MWh) }\end{array}$ \\
\hline Turbine capital cost & 1,030 & 16.1 \\
\hline Balance of system & 322 & 5.0 \\
\hline Financial costs & 110 & 1.7 \\
\hline CapEx & 1,462 & 22.8 \\
\hline OpEx (\$/kW/yr) & 43 & 11.5 \\
\hline FCR (real) [\%] & \multicolumn{2}{|c|}{$5.78 \%$} \\
\hline Net annual energy production (MWh/MW/yr) & \multicolumn{2}{|c|}{3,703} \\
\hline Net capacity factor $(\%)$ & \multicolumn{2}{|c|}{$42.3 \%$} \\
\hline TOTAL LCOE (\$/MWh) & \multicolumn{2}{|c|}{34} \\
\hline
\end{tabular}

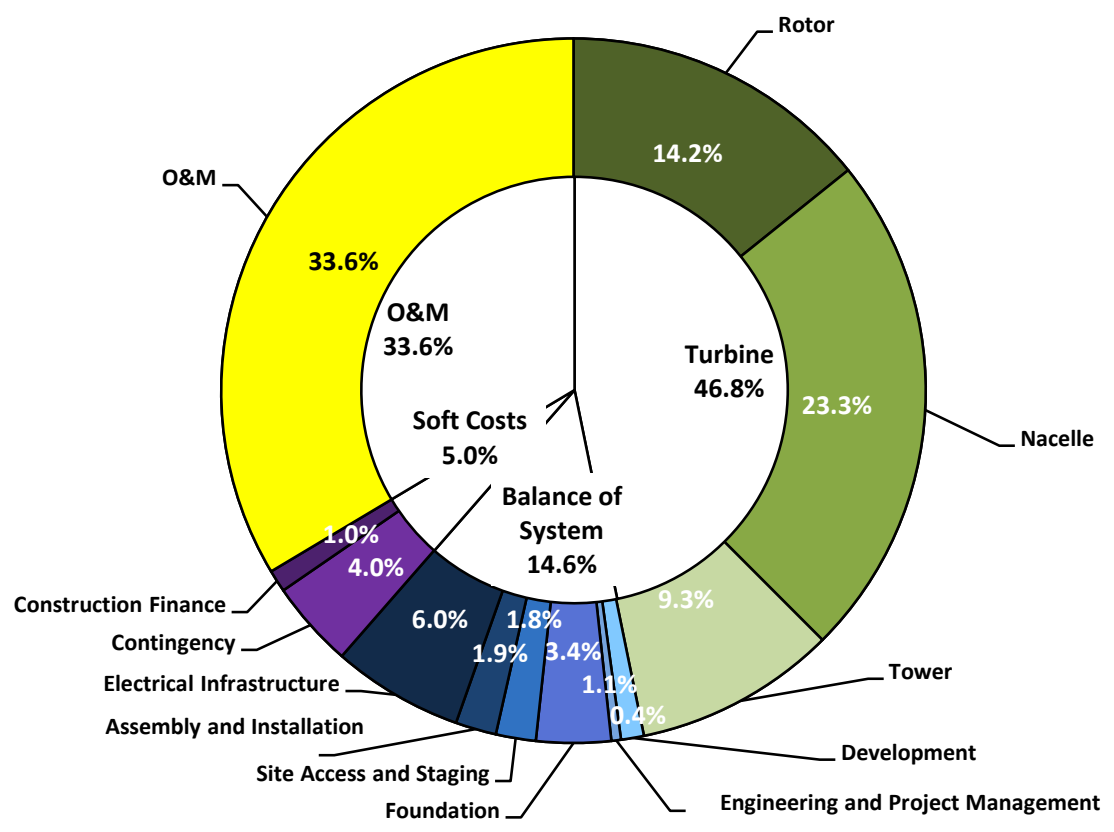

Figure 2. Component-level LCOE contribution for the 2020 land-based-wind reference project operating for 25 years 


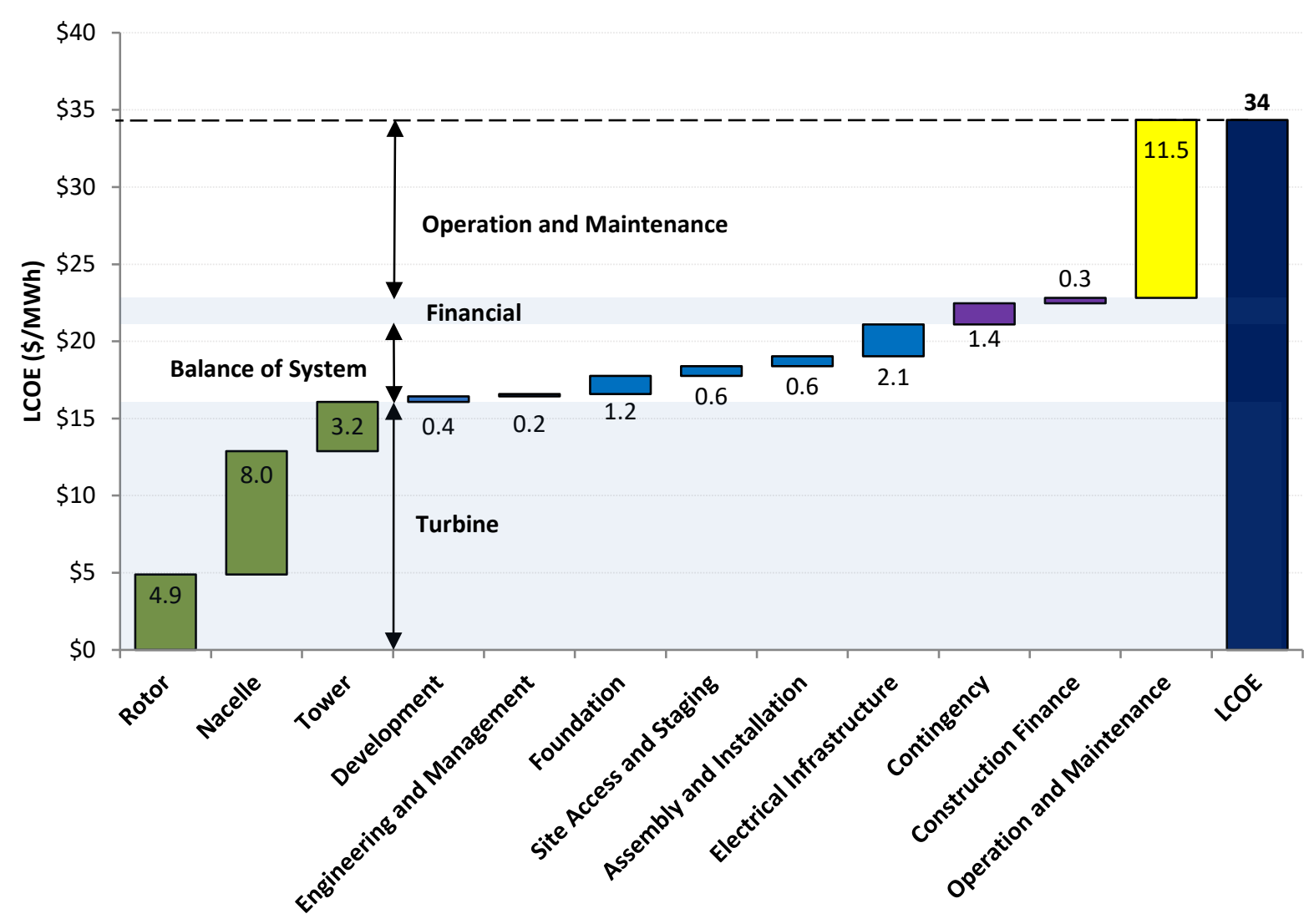

Figure 3. Component-level LCOE breakdown for the 2020 land-based-wind reference project

\subsection{Land-Based-Wind Levelized Cost of Energy Sensitivities}

The input parameters described earlier reflect the land-based reference wind project; however, input parameters for a near-term wind energy project are subject to considerable uncertainty. As a result, it is beneficial to investigate how this variability may impact the LCOE. The sensitivity analysis shown in Figure 4 focuses on the basic LCOE inputs: CapEx, OpEx, capacity factor, and FCR, which is broken into its principal elements: discount rate and economic operational lifetime.

Sensitivity analyses are conducted by holding all reference project assumptions constant and altering only the variable in question. Sensitivity ranges for all parameters except for project design life are pulled from representative industry data or analysis contained in the "Wind Energy Technology Data Update" (Wiser and Bolinger 2021). This selection provides insight into how real-world ranges influence LCOE. Keeping the same 200-MW project size, the sensitivity analysis yields ranges in LCOE from a low of \$26/MWh to a high of \$60/MWh-a 


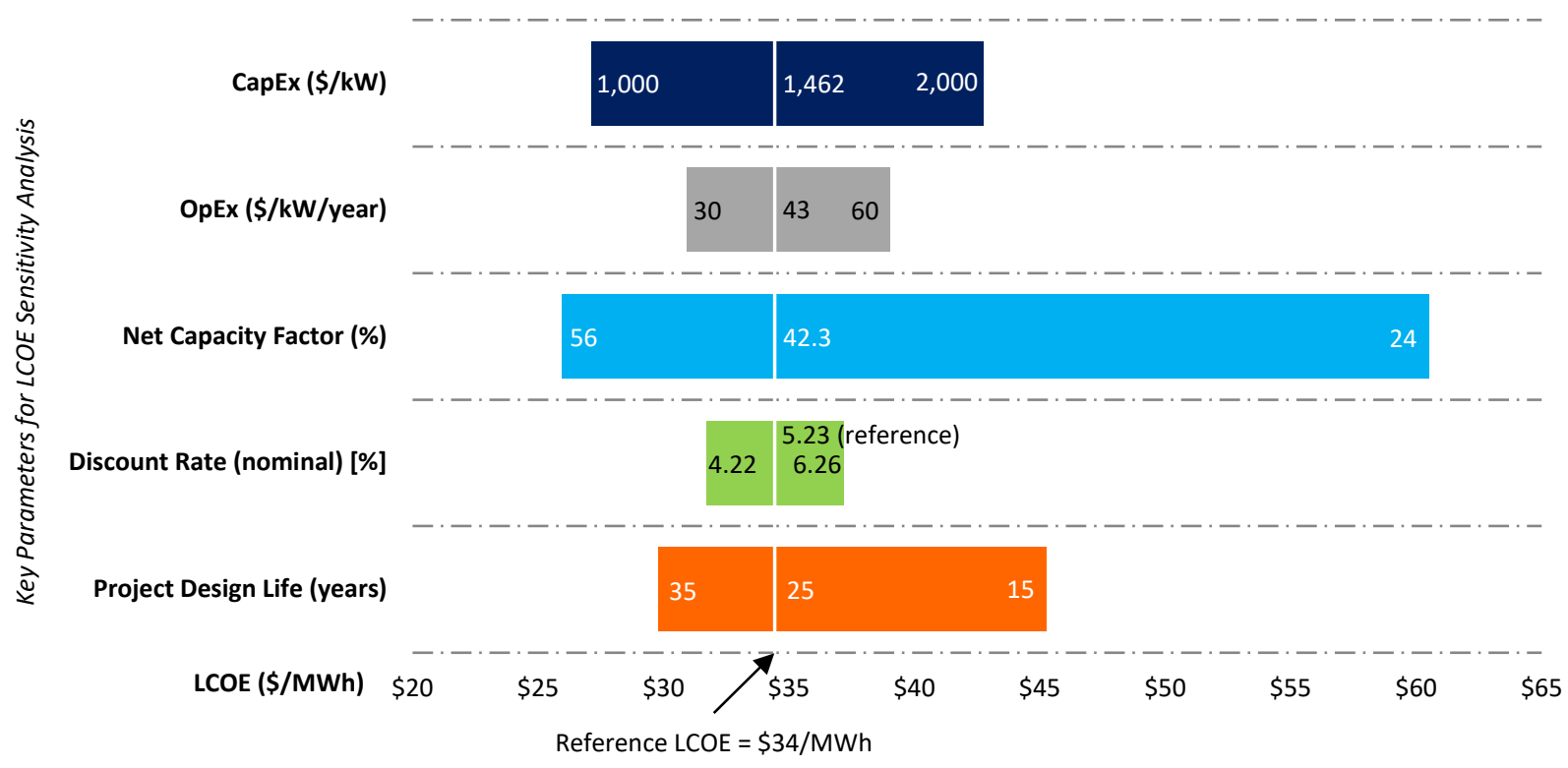

Figure 4. Sensitivity of land-based-wind LCOE to key input parameters

Note: The reference LCOE reflects a representative industry LCOE. Changes in LCOE for a single variable can be understood by moving to the left or right along a specific variable. Values on the x-axis indicate how the LCOE will change as a given variable is altered and all others are assumed constant (i.e., remain reflective of the reference project).

low-to-high delta of $\$ 35 / \mathrm{MWh}$. Within the ranges shown, net capacity factor has the greatest impact on land-based-wind LCOE followed by impacts from CapEx and then project design life. Net capacity factor appears to have the greatest influence with respect to decreasing the LCOE relative to the reference project.

\subsection{Land-Based Supply Curve}

The land-based supply curve illustrates LCOE across the contiguous United States using the 2020 market data from Wiser and Bolinger (2021) and the Wind Integration National Dataset Toolkit (https://www.nrel.gov/grid/wind-toolkit.html). The toolkit provides meteorological conditions for more than 126,000 sites in the continental United States for the years 2007 to 2013. The LCOE for each of the potential wind power plant locations is computed using a sitespecific CapEx and net AEP using a geographic-information-system-based algorithm (Maclaurin et al. 2019). The estimated theoretical capacity for the United States is calculated to be over 9,000 gigawatts $(\mathrm{GW})$, assuming a wind power plant density of $3 \mathrm{MW} /$ square kilometer $\left(\mathrm{km}^{2}\right)$. The LCOE calculated for this theoretical capacity ranges from $\$ 24 / \mathrm{MWh}$ for the best sites in the United States and extends beyond \$175/MWh for nonideal sites. Figure 5 shows this supply curve. For illustrative purposes, the LCOE is calculated for the land-based wind energy projects installed in 2020 using the same site-specific methodology for 109 project locations, which are shown on the supply curve (marked by green circles). In the figure, most of the installed projects in 2020 are grouped near the left side of the supply curve, where LCOE values are lowest, with fewer scattered when moving toward the right of the supply curve with higher LCOE values. Also shown is the calculated LCOE for the reference land-based wind project (indicated by the 
orange diamond), which is based on the 2020 market data from Wiser and Bolinger (2021) and the representative wind site characteristics.

It is important to note that the potential wind power plant capacity available over a range of LCOE varies by geographic region primarily because of the available wind resource characteristics. Incremental costs associated with labor rates, material costs, logistical or siting challenges, and distance to existing transmission infrastructure also contribute to regional differences. This range of costs is illustrated in the supply curve (Figure 5), wherein the cluster of installed wind energy projects in 2020 is toward the lower LCOE end of the supply curve and reflects projects built in the interior region of the United States where the wind resource is favorable. On the other side of the spectrum, the higher LCOE values on the supply curve reflect sites with a relatively lower-quality wind resource and may occur in many regions of the country depending on local meteorological and terrain features.

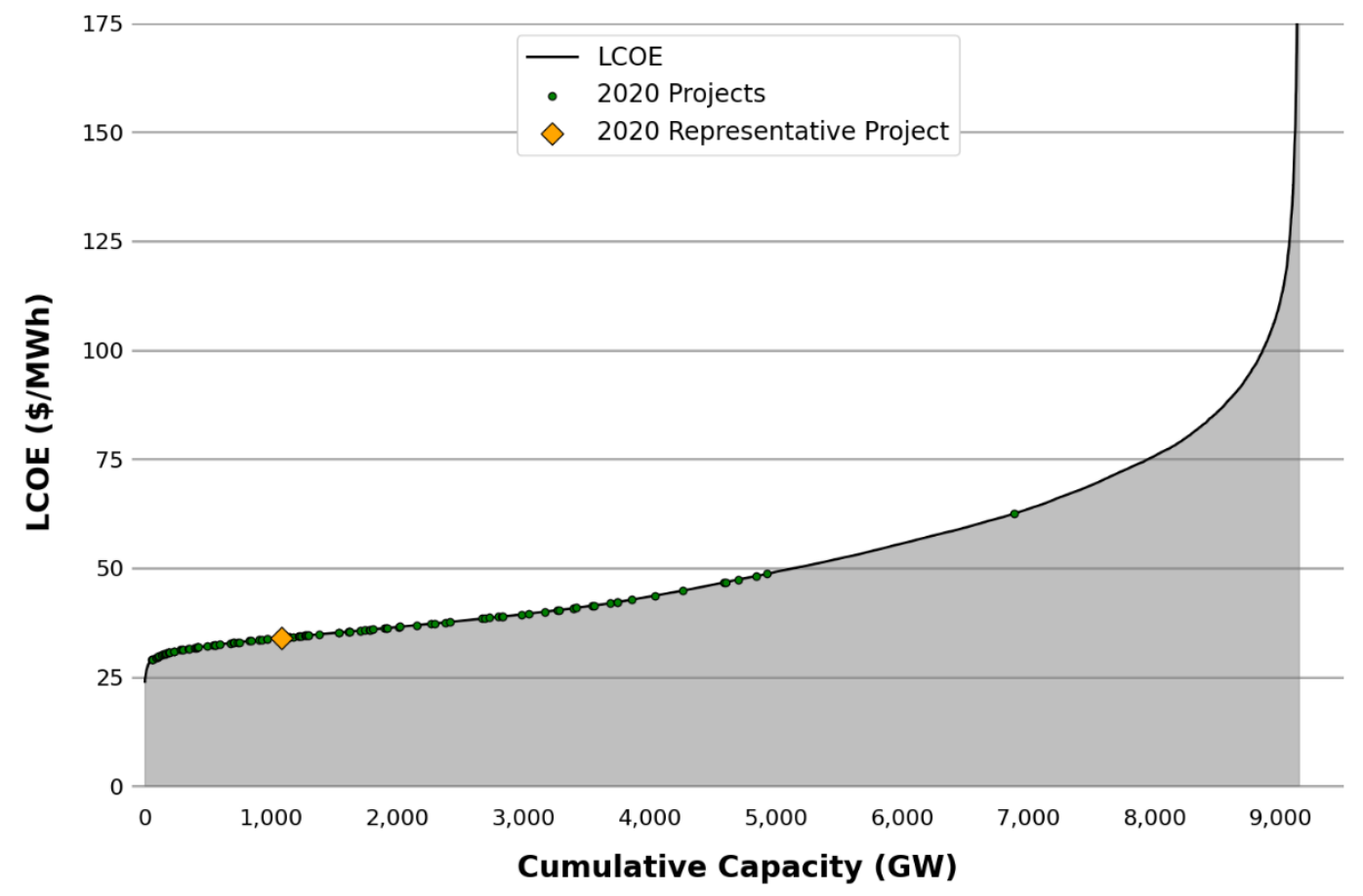

Figure 5. National land-based-wind resource supply curve with 2020 U.S. installed projects

\subsection{Land-Based-Wind Discussion of Results in Context of DOE Goals}

In this section, we present the official land-based-wind GPRA levelized cost of energy end-point target in FY 2030. The GPRA baseline value starts at \$56/MWh (in 2015 USD) set in FY 2016, using the 2015 reference project data presented in Moné et al. (2017). The GPRA target is projected to $\$ 23 / \mathrm{MWh}$ (in 2015 USD) and is derived from the analysis conducted in "Enabling the SMART Wind Power Plant of the Future Through Science-Based Innovation" (Dykes et al. 2017). The pathway for LCOE reduction from the FY 2016 baseline to the FY 2030 target is primarily driven by the increase in AEP through turbine scaling, enhanced control strategies, and reducing wind power plant losses (\$20/MWh [in 2015 USD]). The secondary driver in decreasing LCOE is through reductions in CapEx from wind power plant economies of scale, turbine scaling, and efficient manufacturing capabilities (\$8/MWh [in $2015 \mathrm{USD}]$ ). The 
remaining LCOE reductions are derived from decreasing OpEx through advanced O\&M strategies (\$4/MWh [in 2015 USD]) and lowering the cost of capital from increased certainty of future plant performance and reduced risk (\$1/MWh [in 2015 USD]). This LCOE reduction pathway is illustrated in Figure 6.

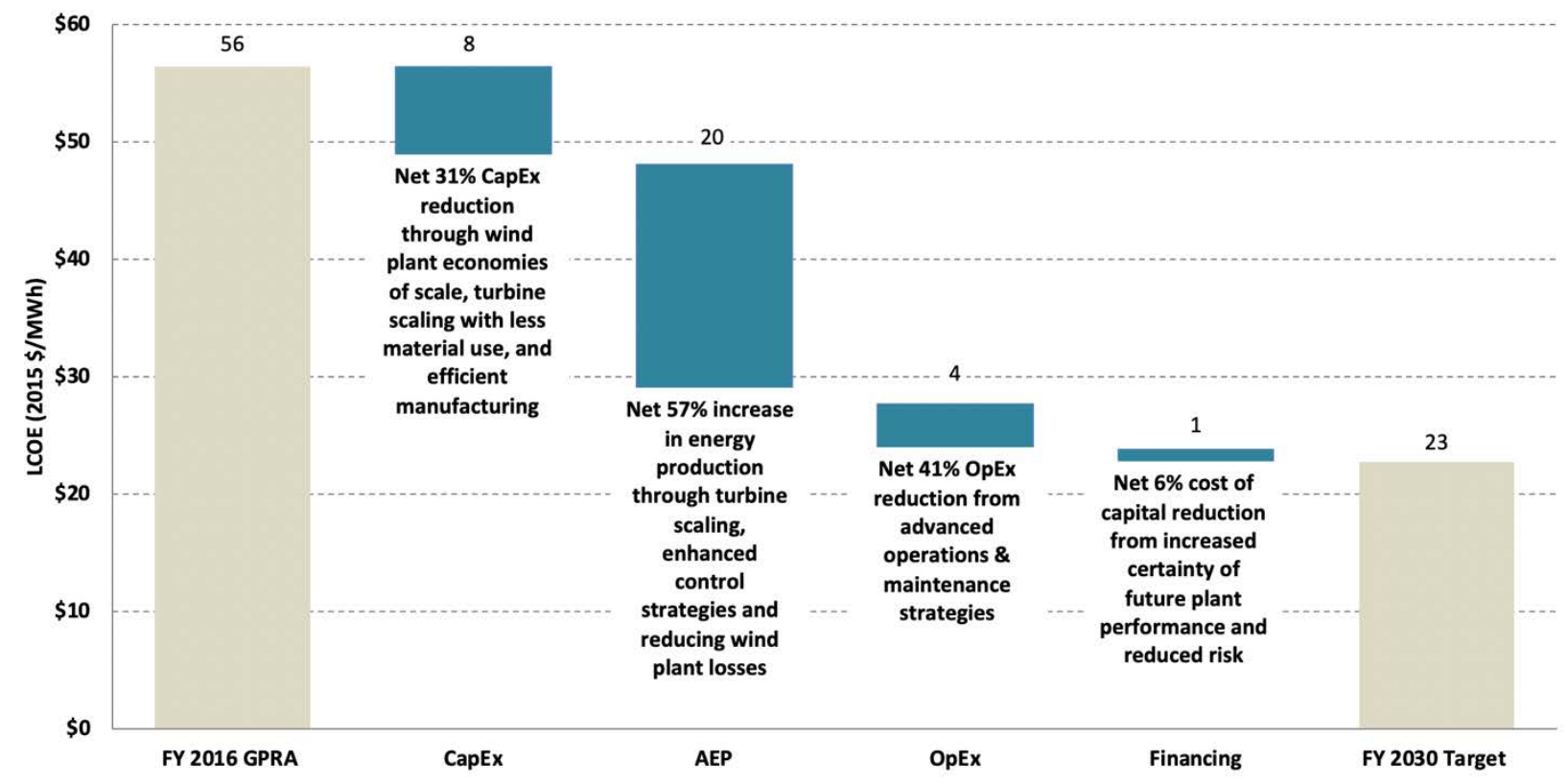

Figure 6. Pathway to LCOE reduction in 2030 by LCOE parameter

The GPRA trajectory and FY 2030 target are shown in Figure 7. To track LCOE progress against the GPRA trajectory, the historical LCOE (starting from FY 2016) and the current LCOE value (in FY 2021) assessed in this year's report are plotted. The GPRA baseline and target levelized cost of energy are reported in 2015 USD for land-based wind energy because WETO will report land-based wind values in 2015 USD. The current and historical LCOE values are labeled as "Actuals" in Figure 7. In the figure, the FY 2021 actual LCOE is reported as \$31/MWh instead of $\$ 34 / \mathrm{MWh}$, as it was converted from 2020 USD to 2015 USD to compare against the GPRA trajectory. ${ }^{17}$

${ }^{17}$ The 2020 USD to 2015 USD was calculated assuming a $-8.4 \%$ cumulative rate of inflation from the Bureau of Labor and Statistics (undated). 


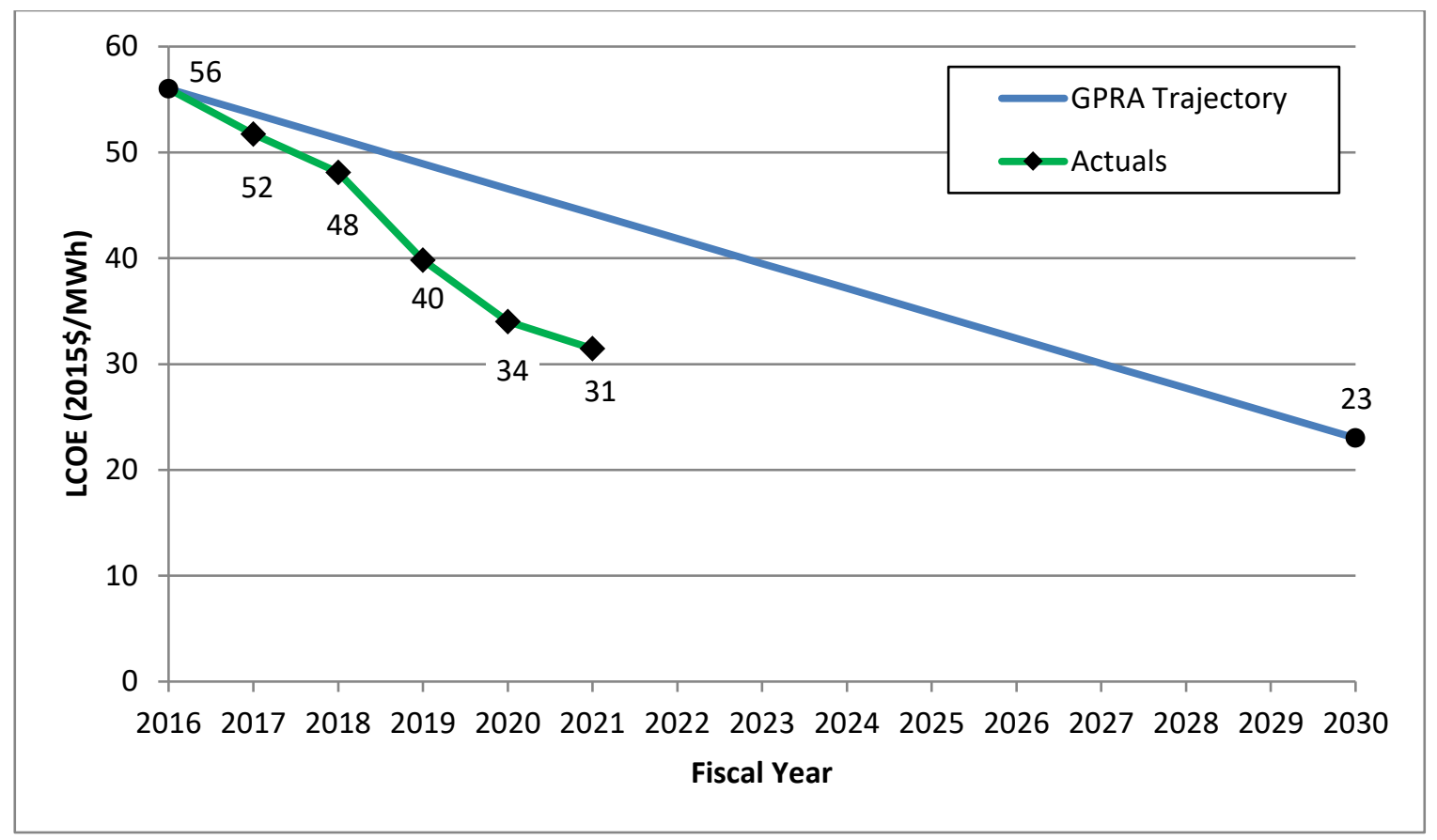

Figure 7. Land-based-wind GPRA cost trajectories for LCOE (in 2015 USD) 


\section{Offshore Wind Energy}

In this section, we outline our methodology and core assumptions for calculating LCOE at representative U.S. projects at the offshore wind reference sites introduced in the "2018 Cost of Wind Energy Review" (Stehly and Beiter 2019). These reference sites reflect spatial conditions that are intended to represent near- to medium-term U.S. project development (see Appendix A for details). During this writing, Vineyard Wind 1 became the first U.S. commercial-scale offshore wind power plant to reach financial close and start construction, so we still rely on global offshore wind market and cost trends to serve as the basis for modeling and U.S. offshore wind costs (Vineyard Wind 2021). In this report, we updated costs and financial parameters to conform with the most recent industry and market developments based on data from NREL's internal offshore wind database, the 2021 ATB, and the "Offshore Wind Market Report: 2021 Edition" (NREL 2021; Musial et al. 2021).

\subsection{Offshore Wind Energy Reference Projects}

For the purposes of this study, we assessed two offshore wind energy technology categories: fixed bottom and floating. The two substructure technologies are used in different site conditions and correspond to separate offshore reference sites used to calculate LCOE (one for fixed bottom and one for floating). Only the fixed-bottom site is used for GPRA reporting purposes.

The offshore wind energy projects we assessed at the fixed-bottom and floating sites consist of 75 wind turbines rated at $8.0 \mathrm{MW}$, yielding a total plant capacity of $600 \mathrm{MW}$. The turbine capacity is estimated from NREL's global offshore wind project database for calendar year 2020. We assume wind turbines are oriented in a grid layout and operate for 25 years without any catastrophic O\&M events. Turbines at the fixed-bottom reference site are assumed to be supported by a monopile substructure $50 \mathrm{~km}$ from cable landfall at a water depth of $34 \mathrm{~m}$, which is representative of characteristics of the wind energy areas located in the North Atlantic region. At the floating reference site, we assume semisubmersible substructure technology is anchored $36 \mathrm{~km}$ from cable landfall at a water depth of $739 \mathrm{~m}$, which is analogous to features of the Pacific Coast. Additional information on the types of fixed-bottom and floating wind substructures can be found in Musial et al. (2021).

The array cable system and electrical line that connects to the offshore substation is a 66-kilovolt collection system design. The export cable from the offshore substation that is used to transfer the power to landfall assumes a 220-kilovolt export system. Specific to the floating reference site, we applied cost premiums to the array and export cable systems to account for the use of dynamic cables. A summary of the two offshore reference site characteristics is provided in Table 12. Further details on the development of the fixed-bottom and floating reference sites are presented in Appendix A. 
Table 12. Offshore Wind Reference Project Parameters (Fixed-Bottom and Floating Substructures)

\begin{tabular}{|c|c|c|}
\hline \multicolumn{3}{|c|}{ Project Parameters } \\
\hline & Fixed Bottom & Floating \\
\hline Region & North Atlantic & Pacific Coast \\
\hline Turbine rated power (MW) & 8.0 & 8.0 \\
\hline Number of wind turbines & 75 & 75 \\
\hline Wind power plant capacity (MW) & 600 & 600 \\
\hline Water depth $(\mathrm{m})$ & 34 & 739 \\
\hline Substructure type & Monopile & Semisubmersible \\
\hline Distance from shore $(\mathrm{km})$ & 50 & 36 \\
\hline Project design life (yr) & 25 & 25 \\
\hline
\end{tabular}

\subsection{Offshore Wind Capital Expenditures}

We estimated CapEx using ORBIT for balance-of-system costs. Soft costs are estimated based on the methodology from ORCA (Nunemaker et al. 2020; Beiter et al. 2016). Turbine CapEx is assumed to remain constant with the "2019 Cost of Wind Energy Review" based on industry data analyzed in the "Offshore Wind Market Report: 2021 Edition" (Stehly et al. 2020; Musial et al. 2021). The representative wind turbine characteristics (i.e., turbine capacity, rotor diameter, and hub height) used as inputs to the model were obtained from NREL's global offshore wind database. The capacity-weighted average turbine installed globally (excluding China) in 2020 was 8.0 MW, with a 159-m rotor diameter at a 102-m hub height. This choice to exclude China from the global capacity weighted average is informed by the fact that the average turbine capacity installed in China in 2020 was 4.0 MW (compared with 8.12 MW in Europe). We expect projected wind turbine technology choices in the U.S. market to follow European market trends in the near-term; therefore, the Chinese data were excluded. We used these turbine parameters in combination with the spatial parameters presented in Table 12 for the fixed-bottom and floating reference sites to calculate CapEx.

The ORBIT and ORCA modeling effort yields a total installed CapEx value of $\$ 3,756 / \mathrm{kW}$ for the fixed-bottom reference site and $\$ 5,351 / \mathrm{kW}$ for the floating reference site. It should be noted that the CapEx estimates for floating offshore wind energy in this analysis assume an 8.0-MW turbine and are not necessarily optimized for floating offshore wind applications; therefore, they may negatively impact the floating CapEx estimates. Note a change from the $2019 \mathrm{COE}$ Review - the Port, Logistics, Staging, and Transportation cost category has been removed from pie charts and summary tables because ORBIT represents these costs during respective installation processes for the wind turbine, substructure, and electrical system, rather than as a unique line item in ORCA.

A breakdown of the CapEx for the fixed-bottom offshore reference project is shown in Figure 8. The shades of green represent the turbine cost, shades of blue represent BOS costs, and shades of purple represent financial costs. Further details on the BOS cost breakdown are provided in Nunemaker et al. (2020). The dollar-value component cost breakdown is shown in Table 13. Figure 9 and Table 14 describe the same breakdown for the floating offshore wind reference project. 


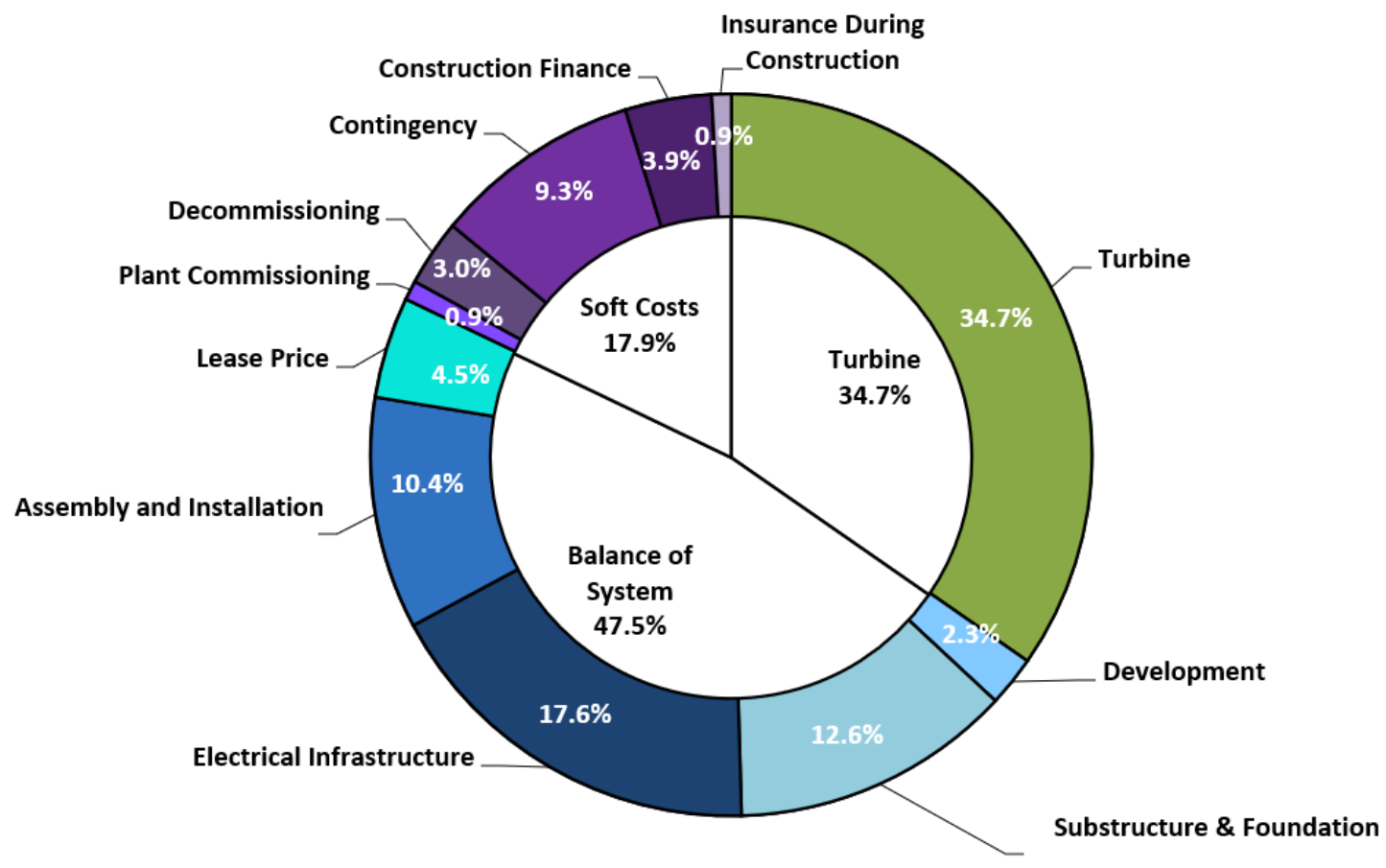

Figure 8. Capital expenditures for the fixed-bottom offshore wind reference project 
Table 13. Fixed-Bottom Offshore CapEx and LCOE Breakdown

\begin{tabular}{|c|c|c|}
\hline & $\begin{array}{l}\text { 8.0-MW Fixed-Bottom } \\
\text { Offshore Wind Turbine } \\
\qquad(\$ / k W)\end{array}$ & $\begin{array}{l}\text { 8.0-MW Fixed-Bottom } \\
\text { Offshore Wind Turbine } \\
\text { (\$/MWh) }\end{array}$ \\
\hline TURBINE CAPITAL COST & 1,301 & 17.7 \\
\hline Development cost & 85 & 1.2 \\
\hline Engineering and management & 2 & 0.0 \\
\hline Substructure and foundation & 474 & 6.4 \\
\hline Electrical infrastructure & 662 & 9.0 \\
\hline Assembly and installation & 390 & 5.3 \\
\hline Lease price & 170 & 2.3 \\
\hline BALANCE OF SYSTEM & 1,782 & 24.2 \\
\hline Insurance during construction & 33 & 0.4 \\
\hline Decommissioning bond & 111 & 1.5 \\
\hline Construction financing & 145 & 2.0 \\
\hline Contingency & 350 & 4.8 \\
\hline Plant commissioning & 33 & 0.4 \\
\hline SOFT COSTS & 672 & 9.1 \\
\hline TOTAL CAPITAL EXPENDITURES & 3,756 & 51.0 \\
\hline
\end{tabular}

Note: Values rounded to the nearest dollar. The electrical infrastructure cost category includes construction and fabrication costs of both the land-based and offshore substations and does not include installation costs for the electrical system, as they are included in the assembly and installation costs.

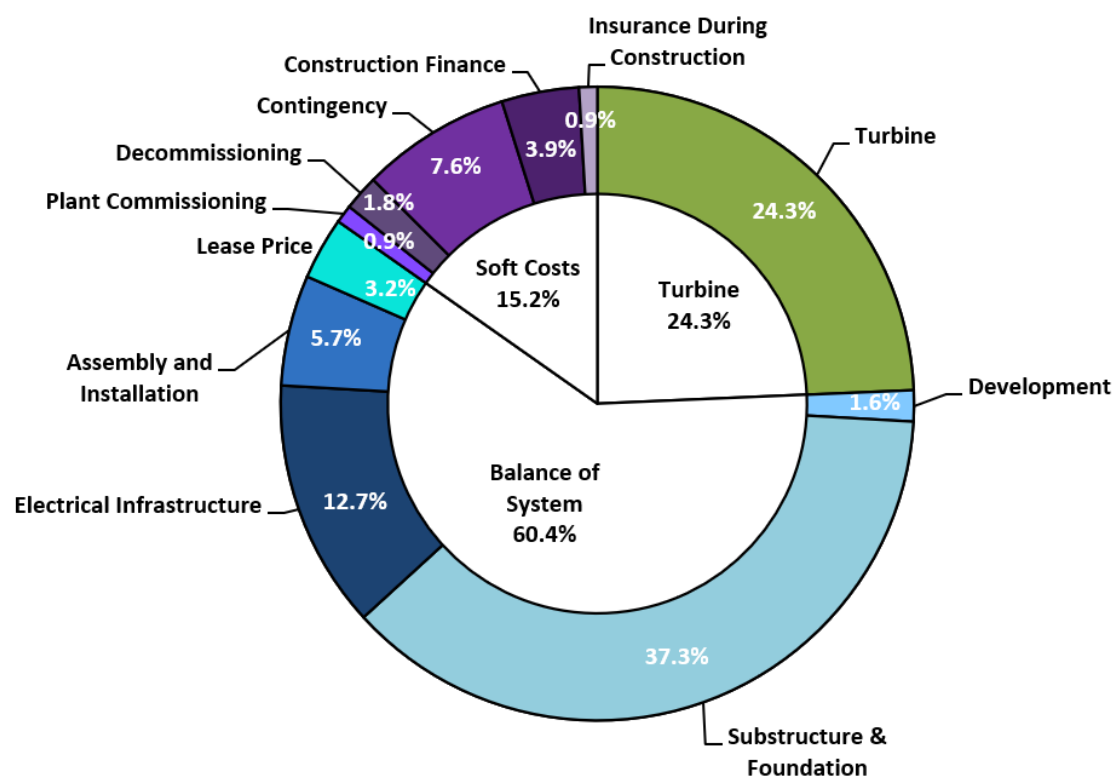

Figure 9. Capital expenditures for the floating offshore wind reference project 
Table 14. Floating Offshore CapEx and LCOE Breakdown

\begin{tabular}{|c|c|c|}
\hline & $\begin{array}{l}\text { 8.0-MW Floating } \\
\text { Offshore Wind Turbine } \\
\qquad(\$ / k W)\end{array}$ & $\begin{array}{l}\text { 8.0-MW Floating } \\
\text { Offshore Wind Turbine } \\
\text { (\$/MWh) }\end{array}$ \\
\hline TURBINE CAPITAL COST & 1,301 & 22.7 \\
\hline Development cost & 85 & 1.5 \\
\hline Engineering and management & 2 & 0.0 \\
\hline Substructure and foundation & 1,996 & 34.9 \\
\hline Electrical infrastructure & 679 & 11.9 \\
\hline Assembly and installation & 302 & 5.3 \\
\hline Lease price & 170 & 3.0 \\
\hline BALANCE OF SYSTEM & 3,234 & 56.5 \\
\hline Insurance during construction & 49 & 0.9 \\
\hline Decommissioning bond & 97 & 1.7 \\
\hline Construction financing & 211 & 3.7 \\
\hline Contingency & 409 & 7.1 \\
\hline Plant commissioning & 49 & 0.9 \\
\hline SOFT COSTS & 816 & 14.3 \\
\hline TOTAL CAPITAL EXPENDITURES & 5,328 & 93.1 \\
\hline
\end{tabular}

Notes:

- The electrical infrastructure cost category includes construction and fabrication costs of both the landbased and offshore substations; this category does not include installation costs for the electrical system, as they are included in the assembly and installation costs.

- Take caution if comparing fixed-bottom and floating offshore wind project costs because there are significant differences in spatial parameters between the representative sites selected for each technology.

There is a notable difference between the cost components that make up the land-based and offshore projects. In the land-based project, $70 \%$ of the cost is related to the wind turbine. For the offshore project, the turbine makes up approximately $24 \%$ and $34 \%$ of the fixed-bottom offshore and floating offshore reference project costs, respectively. The substructure and foundation portion of the BOS costs is the primary cause for the cost differences between the fixed-bottom and floating offshore projects. The analysis indicates that the fixed-bottom substructure is about $24 \%$ of the cost of the floating substructure (assuming a monopile for fixed bottom and a semisubmersible for floating). The other differences in the BOS and financial costs are related to the empirically-based cost and scaling relationships - some of which are a calculated as a percentage of total costs. 


\subsection{Offshore Technology Characteristics and Annual Energy Production}

Offshore wind turbines have increased in size in the recent past and manufacturer announcements suggest that this trend will continue (Shields and Nunemaker 2020). For example, 9.5-MW turbines have been installed, with larger turbines currently in different phases of market and technology development (REVE 2019). As mentioned earlier, we exclude the Chinese market from informing U.S. market technology assumptions because they are more likely to reflect European market trends in the near-term. General Electric is testing a prototype 12- to 14-MW turbine currently, which is scheduled to be available for commercial deployment in 2021 (GE Renewable Energy 2018). Siemens Gamesa (2020) announced a 2024 target for the commercial release of a 14-MW turbine model, with a power boost feature that increases the capacity to $15 \mathrm{MW}$. Vestas also announced a 15-MW platform with the same 2024 serial production target (Vestas 2021). The Chinese manufacturer, MingYang Smart Energy, announced a 16-MW platform with a target prototype in 2023 and commercial production in 2024, which represents a step change over the 2020 average scale of offshore wind turbine technology deployed in China (MingYang 2021). Incorporating larger turbines in a project's design contributes to LCOE reductions via reduced balance-of-plant and O\&M costs (Shields et al. 2021). Larger turbine sizes are made possible in offshore applications, partly because there are fewer transportation and installation limits than for land-based wind energy projects.

\subsubsection{Wind Turbine Parameters}

The offshore wind turbine technology characteristics for this analysis are calculated using a capacity-weighted average of the global offshore wind projects installed in 2020 (excluding China). The results of this calculation yield a turbine rating of $8.0 \mathrm{MW}$, rotor diameter of $159 \mathrm{~m}$, and a hub height of $102 \mathrm{~m}$, as reported in Musial et al. (2021). These values and additional assumptions for the offshore turbine characteristics are summarized in Table 15.

Table 15. Reference Offshore Wind Turbine Parameter Input Assumptions

\begin{tabular}{|l|c|}
\hline \multicolumn{2}{|c|}{ Wind Turbine Parameters } \\
\hline Turbine rated power $(\mathrm{MW})$ & 8.0 \\
\hline Turbine rotor diameter $(\mathrm{m})$ & 159 \\
\hline Turbine hub height $(\mathrm{m})$ & 102 \\
\hline Drivetrain design & Geared \\
\hline Cut-in wind speed $(\mathrm{m} / \mathrm{s})$ & 3 \\
\hline Cut-out wind speed $(\mathrm{m} / \mathrm{s})$ & 25 \\
\hline
\end{tabular}

\subsubsection{Wind Resource}

In this report, we assessed the wind resource for the fixed-bottom and floating reference sites located on the North Atlantic and Pacific Coast, respectively. The details of this analysis and its results are presented in Appendix A. The annual average wind speed in the North Atlantic region was assessed to be $8.43 \mathrm{~m} / \mathrm{s}$ at $50 \mathrm{~m}(9.12 \mathrm{~m} / \mathrm{s}$ at a hub height of $102 \mathrm{~m})$, and $7.67 \mathrm{~m} / \mathrm{s}$ at $50 \mathrm{~m}$ $(8.30 \mathrm{~m} / \mathrm{s}$ at a hub height of $102 \mathrm{~m})$ for the Pacific Coast. Note that the same wind resources are used for the 2020 study as were used in 2018. Hub-height wind speeds have been extrapolated 
from the 2018 hub height of $93.8 \mathrm{~m}$ up to the corresponding 2020 hub height of $102 \mathrm{~m}$ using the power law and a wind shear exponent of 0.1 . The wind resource parameters are summarized in Table 16.

Table 16. Reference Offshore Wind Resource Input Assumptions

\begin{tabular}{|l|c|c|}
\hline \multicolumn{3}{|c|}{ Wind Resource Characteristics } \\
\hline Annual average wind speed at a 50-m height $(\mathrm{m} / \mathrm{s})$ & 8.43 & 7.67 \\
\hline Annual average wind speed at a 102-m hub height $(\mathrm{m} / \mathrm{s})$ & 9.12 & 8.3 \\
\hline Weibull k & 2.1 & 2.1 \\
\hline Shear exponent & 0.1 & 0.1 \\
\hline
\end{tabular}

\subsubsection{Losses and Availability}

The U.S. offshore wind reference project considers losses from wind power plant array wake impacts, inefficiencies in power collection and transmission (export cable), and losses from wind power plant availability. These losses and availability estimates are determined using ORCA (Beiter et al. 2016), which performs calculations based on a specific wind power plant layout and site-specific meteorological ocean conditions. The total system losses for the fixed-bottom technology in the North Atlantic region are $15.7 \%$, whereas the system losses for the floating offshore technology in the Pacific Coast region are $20.8 \%$. The primary differences in loss between these offshore technologies are the additional electrical cable losses for floating wind in deeper waters (i.e., $34 \mathrm{~m}$ versus $739 \mathrm{~m}$ ), and wake losses from the different reference sites. Table 17 summarizes the losses and availability estimates for the fixed-bottom and floating offshore wind technologies.

Table 17. Reference Offshore Wind Total Losses

\begin{tabular}{|l|c|c|}
\hline & $\begin{array}{c}\text { Lorth Atlantic } \\
\text { (Fixed Bottom) }\end{array}$ & $\begin{array}{c}\text { Pacific Coast } \\
\text { (Floating) }\end{array}$ \\
\hline Total system losses (\%) & $15.7 \%$ & $20.8 \%$ \\
\hline
\end{tabular}

\subsubsection{Annual Energy Production}

The net AEP is calculated using the wind turbine technology parameters and wind resource inputs, and by applying the appropriate losses and availability estimates. The net AEP is calculated for the offshore wind reference project for both fixed-bottom and floating offshore applications using ORCA. The resulting net AEP for the fixed-bottom configuration in the North Atlantic region is 4,283 $\mathrm{MWh} / \mathrm{MW} /$ year, with a $48.9 \%$ net capacity factor, and 3,332 $\mathrm{MWh} / \mathrm{MW} / \mathrm{year}$ for the floating configuration in the Pacific Coast region, with a $38.0 \%$ net capacity factor. These values are summarized in Table 18. 
Table 18. Reference Offshore Wind Net Annual Energy Production

\begin{tabular}{|l|c|c|}
\hline \multicolumn{2}{|c|}{ Net Annual Energy Production } \\
\hline & $\begin{array}{c}\text { North Atlantic } \\
\text { (Fixed Bottom) }\end{array}$ & $\begin{array}{c}\text { Pacific Coast } \\
\text { (Floating) }\end{array}$ \\
\hline Net energy capture (MWh/MW/year) & 4,283 & 3,332 \\
\hline Net capacity factor (\%) & $48.9 \%$ & $38.0 \%$ \\
\hline
\end{tabular}

Capacity factors in the United States are expected to vary widely depending on the project location and wind turbine technology. Improving the performance of offshore wind turbines and arrays has been a continued focus of industry and research activities. More information on the global trends for offshore wind power plant performance can be found in Musial et al. (2017).

\subsection{Offshore Wind Operation and Maintenance Expenditures}

OpEx can vary greatly between projects; however, the two largest cost drivers are the distance from the project to the maintenance facilities and the meteorological ocean climate at the site (Maples et al. 2013; Pietermen et al. 2011). Beiter et al. (2016) evaluated the O\&M for fixedbottom and floating substructures located at sites with various wave heights, water depths, and distances from ports informed by parametric studies using the Energy Research Centre of the Netherlands O\&M Tool. ${ }^{18}$ The North Atlantic fixed-bottom and Pacific Coast floating offshore reference projects assume the same operational costs (e.g., annual leases and fees) of $\$ 30 / \mathrm{kW} / \mathrm{yr}$, whereas the maintenance expenditures differ between the two because they each use a different maintenance strategy (i.e., in situ versus tow to shore) and have distinctive site characteristics (i.e., distance from operations port, meteorological ocean conditions, and water depth), resulting in $\$ 110 / \mathrm{kW} / \mathrm{yr}$ for the fixed-bottom project and $\$ 118 / \mathrm{kW} / \mathrm{yr}$ for the floating project. These O\&M costs and the LCOE component breakdown are shown in Table 19.

Table 19. Offshore Wind Reference Project OpEx

\begin{tabular}{|c|c|c|c|c|}
\hline & \multicolumn{2}{|c|}{$\begin{array}{l}\text { North Atlantic } \\
\text { (Fixed Bottom) }\end{array}$} & \multicolumn{2}{|c|}{$\begin{array}{l}\text { Pacific Coast } \\
\text { (Floating) }\end{array}$} \\
\hline & (\$/kW/yr) & $\begin{array}{l}\text { (\$/kilowatt- } \\
\text { hour [kWh]) }\end{array}$ & (\$/kW/yr) & (\$/kWh) \\
\hline Operation & 30 & 7.1 & 30 & 9.1 \\
\hline Maintenance & 80 & 18.7 & 88 & 26.3 \\
\hline OpEx & 110 & 25.8 & 118 & 35.4 \\
\hline
\end{tabular}

\subsection{Offshore Finance}

This section describes the financing assumptions for the report's representative offshore wind (both fixed bottom and floating) reference projects in the United States in 2020. In this report, the offshore financing assumptions are consistent with those developed for NREL's ATB (Feldman et al. 2020).

\footnotetext{
${ }^{18}$ Operation and maintenance costs for offshore wind energy projects are assumed to include labor, vessels, equipment, scheduled maintenance, unscheduled maintenance, land-based support, and administration.
} 


\subsubsection{Discount Rate}

An individual project's financing terms reflect its specific risk profile, assumptions, and ranges of nominal discount rates for offshore wind energy. The generic assumptions used for this report are consistent with NREL's 2021 ATB (Feldman et al. 2020), which were derived from industry interviews and a literature review. For this analysis, we assumed the discount rate and other economic evaluation metrics to be similar for the North Atlantic and Pacific Coast representative projects. The updated nominal WACC for 2021 is $5.29 \%$, which corresponds to a real WACC of $2.72 \%$, assuming a $2.5 \%$ inflation rate. Underlying assumptions for marginal tax rate and inflation are consistent with those presented in Section 4.5.1.

\subsubsection{Economic Evaluation Metrics}

To determine the LCOE for the 2020 representative offshore wind projects, a similar FCR methodology that was used for the land-based representative wind project is applied (see Section 4.5) and informed by the 2021 ATB (NREL 2021). The FCR includes the present value of the accumulated depreciation benefit and ignores bonus depreciation. Assuming a project life of 25 years and discount rates and depreciation benefits as calculated, the offshore reference project nominal and real FCR for fixed-bottom and floating technologies is $7.64 \%$ and $5.82 \%$, respectively. Table 20 presents a summary of nominal and real WACC, CRF, and FCR that is used throughout the offshore analysis.

Table 20. Summary of Offshore Reference Project Economic Evaluation Metrics

\begin{tabular}{|lcc|} 
& $\begin{array}{c}\text { North Atlantic and Pacific Coast } \\
\text { (Fixed Bottom and Floating) } \\
\text { Nominal }\end{array}$ & $\begin{array}{c}\text { Real } \\
\text { WACC (\%) }\end{array}$ \\
\hline CRF (\%) & $5.29 \%$ & $2.72 \%$ \\
\hline FCR (\%) & $7.30 \%$ & $5.60 \%$ \\
\hline
\end{tabular}

\subsection{Offshore Reference Project Levelized Cost of Energy}

Based on the offshore wind turbine technology parameters, site conditions, wind resource, and cost estimates, we used the CapEx, FCR, OpEx, and AEP to calculate LCOE for the 2020 offshore reference wind power plant for fixed-bottom and floating technologies. LCOE for the fixed-bottom North Atlantic representative project is calculated at $\$ 77 / \mathrm{MWh}$ and $\$ 129 / \mathrm{MWh}$ for the representative floating project on the Pacific Coast. Table 21 summarizes the fixed-bottom costs for the primary components (including their contribution to LCOE) in the North Atlantic region. The graphic in Figure 10 illustrates the LCOE breakdown for the primary components of the North Atlantic wind power plant, whereas Figure 11 provides a graphical representation of LCOE by line item. Table 22, Figure 12, and Figure 13 show the cost values, LCOE breakdown, and LCOE values for the floating project in the Pacific Coast region. 
Table 21. Fixed-Bottom Offshore Wind LCOE and Reference Projects Cost Breakdown

\begin{tabular}{|c|c|c|}
\hline & $\begin{array}{l}\text { 8.0-MW Fixed-Bottom Offshore } \\
\text { Wind Turbine } \\
(\$ / k W)\end{array}$ & $\begin{array}{l}\text { 8.0-MW Fixed-Bottom Offshore } \\
\text { Wind Turbine } \\
\text { (\$/MWh) }\end{array}$ \\
\hline Turbine capital cost & 1,301 & 17.7 \\
\hline Balance of system & 1,782 & 24.2 \\
\hline Financial costs & 672 & 9.1 \\
\hline CapEx & 3,756 & 51.0 \\
\hline OpEx (\$/kW/yr) & 110 & 25.8 \\
\hline FCR (real) [\%] & \multicolumn{2}{|c|}{$5.8 \%$} \\
\hline Net AEP (MWh/MW/yr) & \multicolumn{2}{|c|}{4,283} \\
\hline Net capacity factor (\%) & \multicolumn{2}{|c|}{$48.9 \%$} \\
\hline Total LCOE (\$/MWh) & \multicolumn{2}{|c|}{77} \\
\hline
\end{tabular}

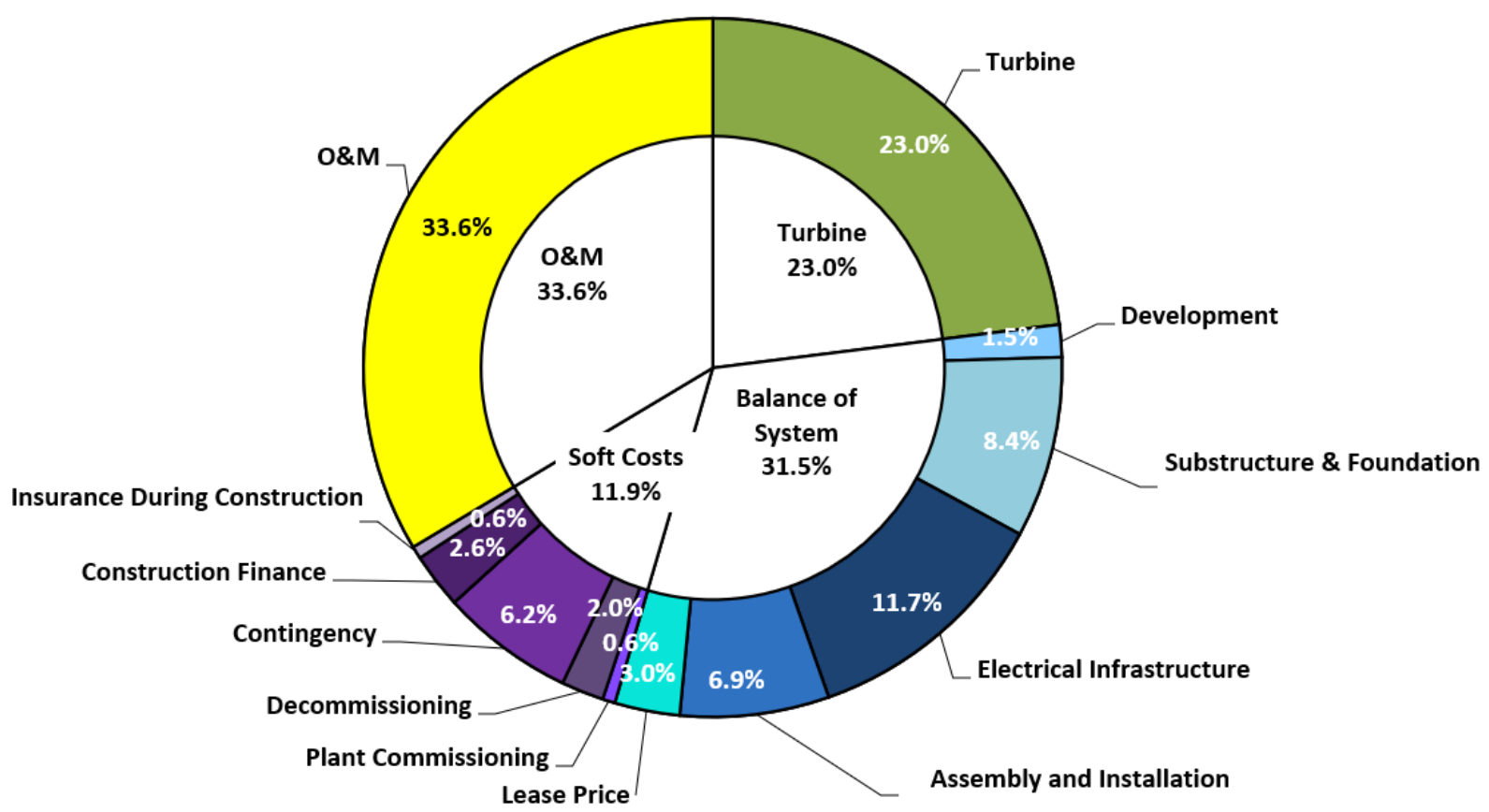

Figure 10. Component-level LCOE contribution for the 2020 fixed-bottom offshore wind reference project operating for 25 years 


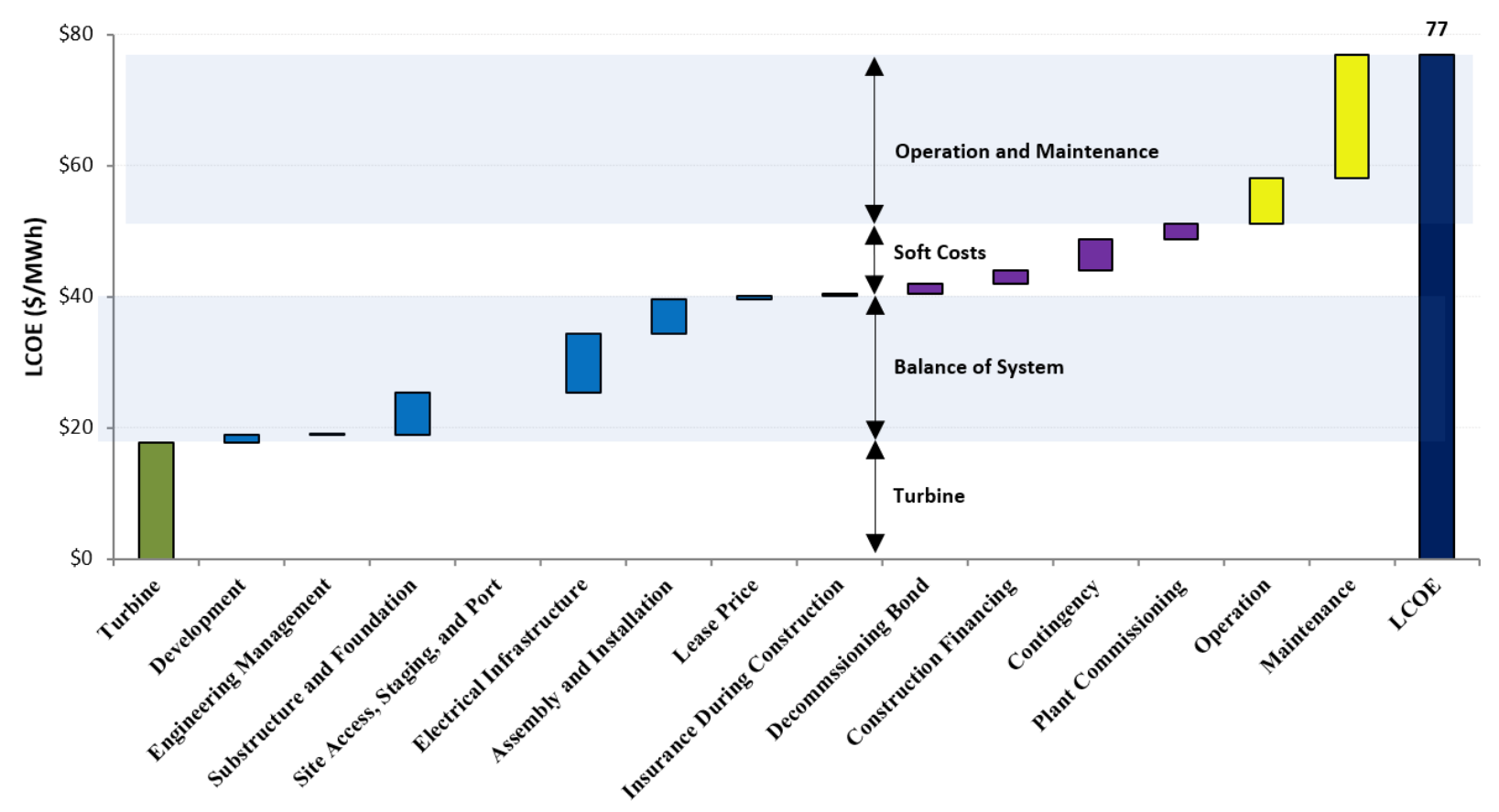

Figure 11. Component-level cost breakdown for the 2020 fixed-bottom offshore wind reference project

Table 22. Floating Offshore Wind LCOE and Reference Projects Cost Breakdown

\begin{tabular}{|c|c|c|}
\hline & $\begin{array}{l}\text { 8.0-MW Floating Offshore Wind } \\
\text { Turbine } \\
(\$ / k W)\end{array}$ & $\begin{array}{l}\text { 8.0-MW Floating Offshore Wind } \\
\text { Turbine } \\
\text { (\$/MWh) }\end{array}$ \\
\hline Turbine capital cost & 1,301 & 22.7 \\
\hline Balance of system & 3,234 & 56.5 \\
\hline Financial costs & 816 & 14.3 \\
\hline CapEx & 5,351 & 93.5 \\
\hline OpEx (\$/kW/yr) & 118 & 35.4 \\
\hline FCR (real) [\%] & \multicolumn{2}{|c|}{$5.8 \%$} \\
\hline Net AEP (MWh/MW/yr) & \multicolumn{2}{|c|}{3,332} \\
\hline Net capacity factor (\%) & \multicolumn{2}{|c|}{$38.0 \%$} \\
\hline Total LCOE (\$/MWh) & \multicolumn{2}{|c|}{129} \\
\hline
\end{tabular}




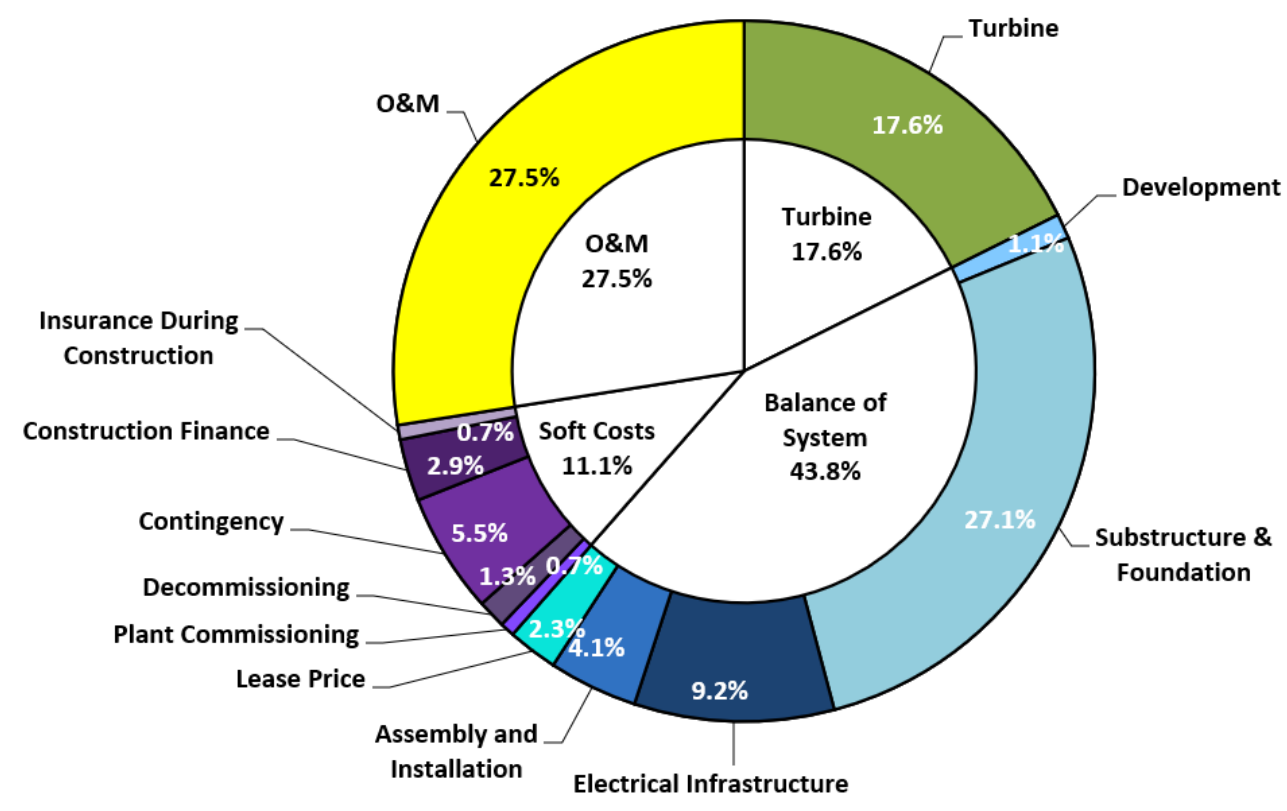

Figure 12. Component-level LCOE contribution for the 2020 floating offshore wind reference project operating for 25 years

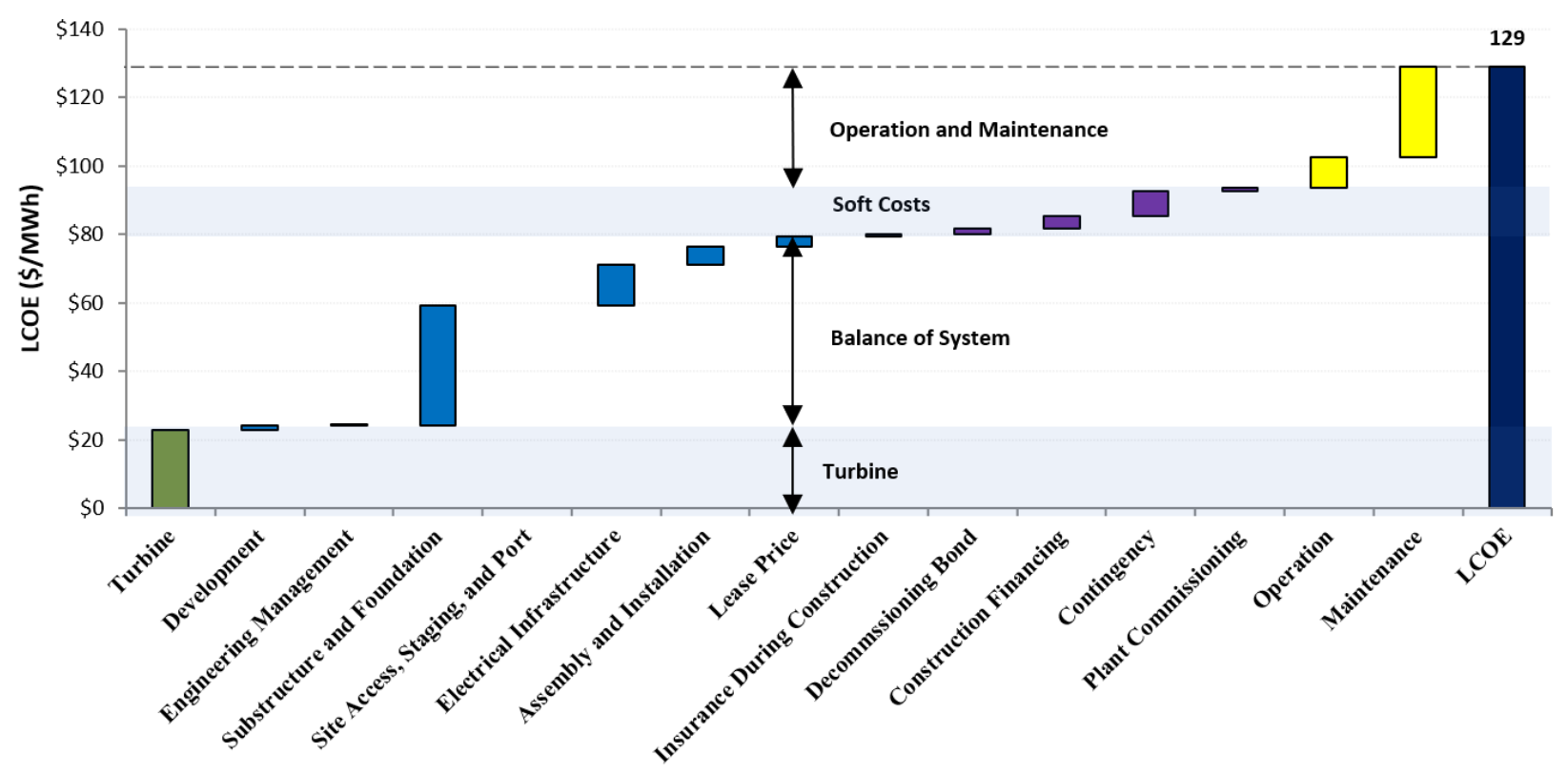

Figure 13. Component-level cost breakdown for the 2020 floating offshore wind reference project

\subsection{Offshore Levelized Cost of Energy Sensitivities}

The LCOE parameters described earlier represent the fixed-bottom and floating offshore reference wind projects; however, input parameters for a near-term wind project are subject to considerable uncertainty. Hence, it is beneficial to investigate how this variability may impact 
the LCOE. The sensitivity analysis shown in Figure 14 (for the North Atlantic fixed-bottom site) and Figure 15 (for the Pacific Coast floating site) focuses on the basic LCOE inputs: CapEx, OpEx, net capacity factor, and FCR, which are broken into two principal elements-discount rate and economic operational lifetime. We determined the sensitivity ranges for the LCOE inputs by examining the globally installed offshore wind projects in 2020 reported in the "Offshore Wind Market Report: 2021 Edition" (Musial et al. 2021) and NREL's offshore wind database.

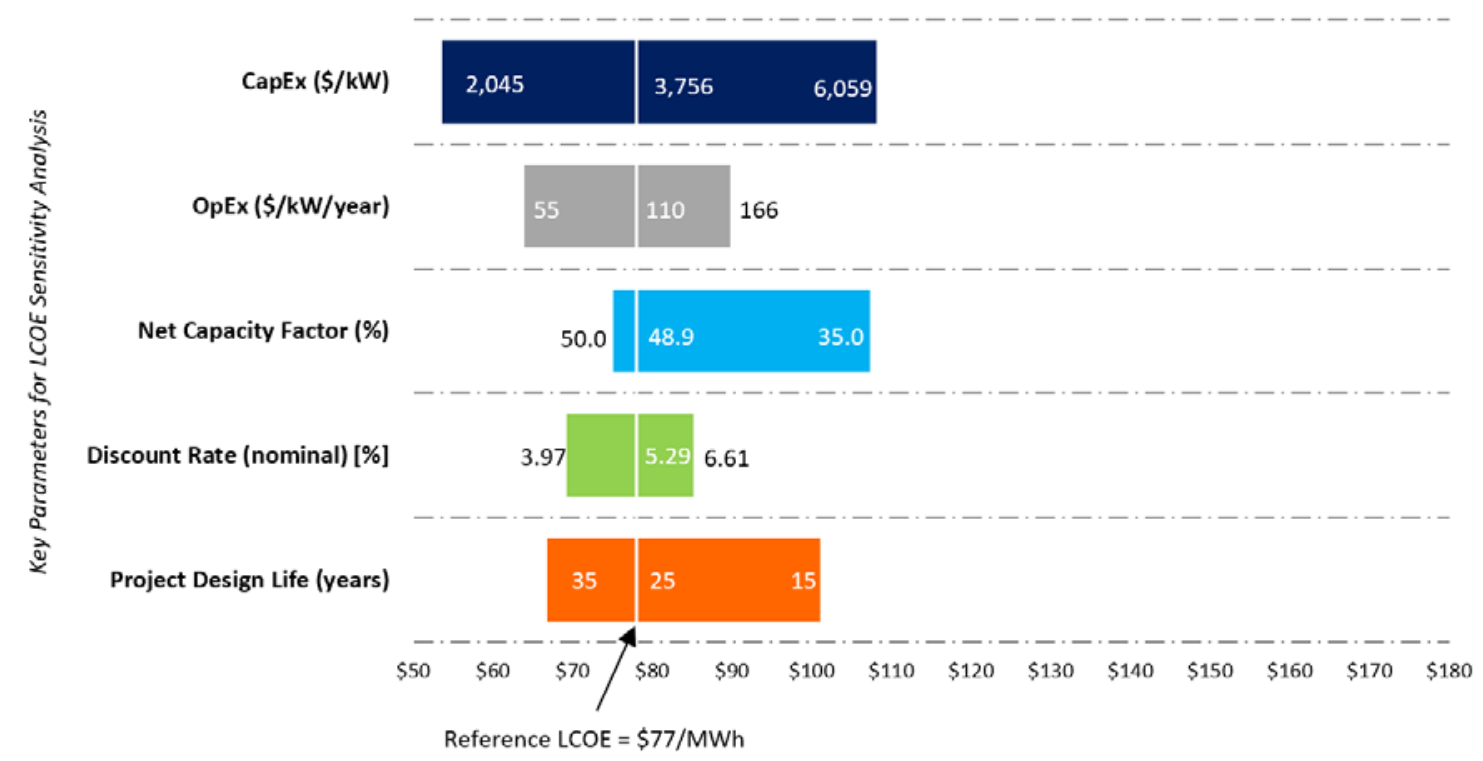

Figure 14. Sensitivity of fixed-bottom offshore wind LCOE to key input parameters

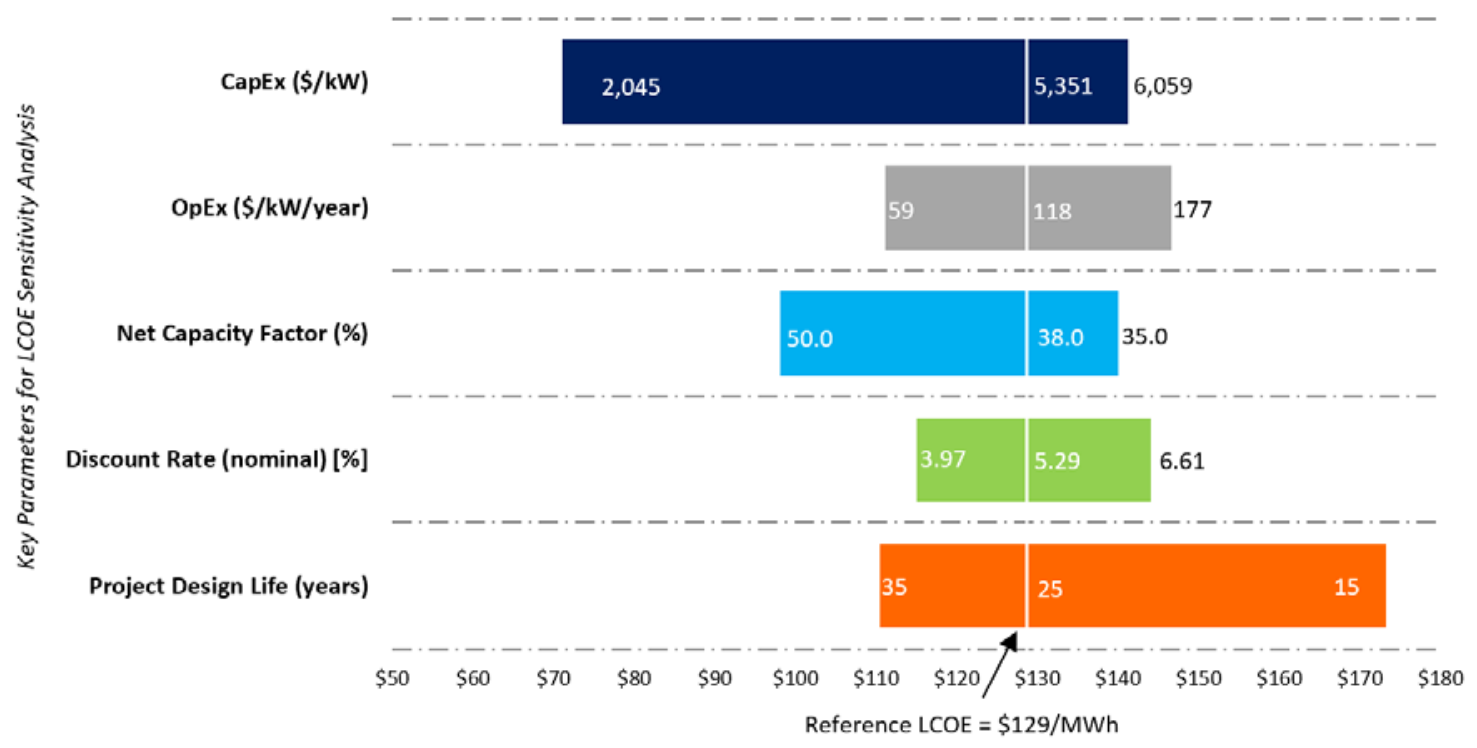

Figure 15. Sensitivity of floating offshore wind LCOE to key input parameters 
Note: The reference LCOE reflects a representative industry LCOE. Changes in LCOE for a single variable can be understood by moving to the left or right along a specific variable. Values on the $\mathrm{x}$-axis indicate how the LCOE

will change as a given variable is altered and all others are assumed constant (i.e., remain reflective of the reference project).

Sensitivity analyses are conducted by holding all reference project assumptions constant and altering only the variable in question. Sensitivity ranges are selected to represent the highs and lows observed in the industry and from the data in the "Offshore Wind Market Report: 2021 Edition" (Musial et al. 2021). This selection provides insight into how real-world ranges influence LCOE. Keeping the same 600-MW project size, the sensitivity analysis yields ranges in LCOE from a low of $\$ 54 / \mathrm{MWh}$ to a high of $\$ 108 / \mathrm{MWh}$ for fixed-bottom configurations (Figure 14), and a low of $\$ 71 / \mathrm{MWh}$ to a high of $\$ 173 / \mathrm{MWh}$ for floating configurations (Figure 15). Within the ranges shown, CapEx and project design life are the two factors that are shown to have the greatest impact on offshore wind LCOE, with CapEx having the greatest influence on decreasing LCOE relative to the reference projects.

\subsection{Offshore Wind Energy Supply Curve}

Nearly 5,500 GW of offshore wind + gross resource potential has been estimated for the "2020 Cost of Energy Review" covering the continental United States (excluding Alaska and Hawaii). This gross resource potential does not exclude any areas of competing use or exclusion areas ${ }^{19}$ and was calculated using a geographic-information-system-based algorithm documented in Beiter et al. (2017). For the offshore wind supply curve, the LCOE for each of the potential wind power plant locations is computed using CapEx, OpEx, and net AEP. LCOE varies by offshore geographic region primarily because of the available wind resource, distance from port, and water depth. Incremental costs associated with labor rates, material costs, logistical or siting challenges, and distance to existing transmission infrastructure also contribute to regional differences.

LCOE, which includes the cost of export cables and onshore spur lines and was calculated for this gross resource area, ranged from $\$ 67 / \mathrm{MWh}$ to $\$ 233 / \mathrm{MWh}$. Figure 16 illustrates the supply curve of the gross offshore wind resource potential and highlights the 2020 fixed-bottom (marked with an orange diamond) and floating (marked with a blue diamond) offshore wind reference sites.

\footnotetext{
${ }^{19}$ This gross resource potential compares to nearly 2,060 GW of "technical resource capacity" when considering various competing use and exclusion areas (Musial et al. 2016).
} 


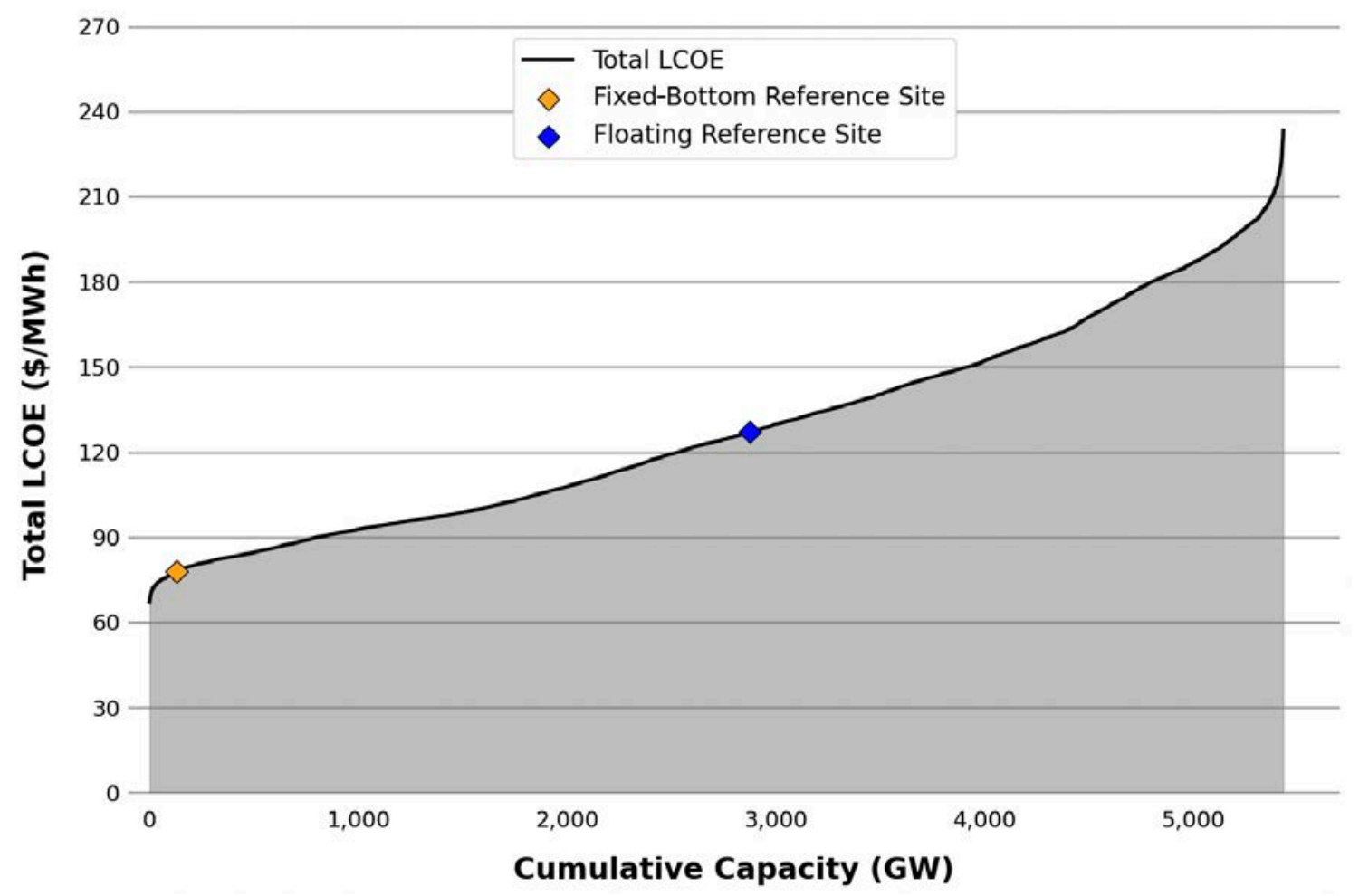

Figure 16. National fixed-bottom and floating offshore wind supply curve

\subsection{Offshore Discussion of Results in Context of DOE Goals}

In this section, we present the fixed-bottom offshore wind GPRA levelized cost of energy 2030 target. The GPRA trajectory was baselined in FY 2019 using 2018 reference project data reported in Stehly et al. (2019). The baseline LCOE starts at \$89/MWh (in 2018 USD) and is projected to reach the FY 2030 GPRA target of \$51/MWh (in 2018 USD). The GPRA baseline and target LCOE are reported in 2018 USD because WETO will report fixed-bottom offshore wind values to Congress in 2018 USD.

The FY 2030 target analysis estimates the future CapEx and O\&M costs using ORCA (Beiter et al. 2016) and assuming a wind power plant comprising 15-MW wind turbines placed in the North Atlantic reference site. The cost reduction trajectory is also informed by technology innovations considered in the spatial economic analysis by Beiter et al. (2016). This future technology assessment estimates the wind power plant's CapEx to be $\$ 3,476 / \mathrm{kW}$, with an O\&M cost of $\$ 60 / \mathrm{kW} / \mathrm{yr}$ operating at a $58 \%$ net capacity factor. The future financial assumptions are informed by NREL's 2019 ATB, with an operation life of 25 years for a 5.7\% real FCR. The 2030 LCOE calculated from this analysis is \$51/MWh and is designated as the FY 2030 GPRA target. To track LCOE progress against the GPRA trajectory, historical LCOE values and the FY 2021 LCOE value assessed in this year's report are plotted in Figure 17. The reported LCOE value for FY 2021 is calculated in Section 5.6 of this report. 


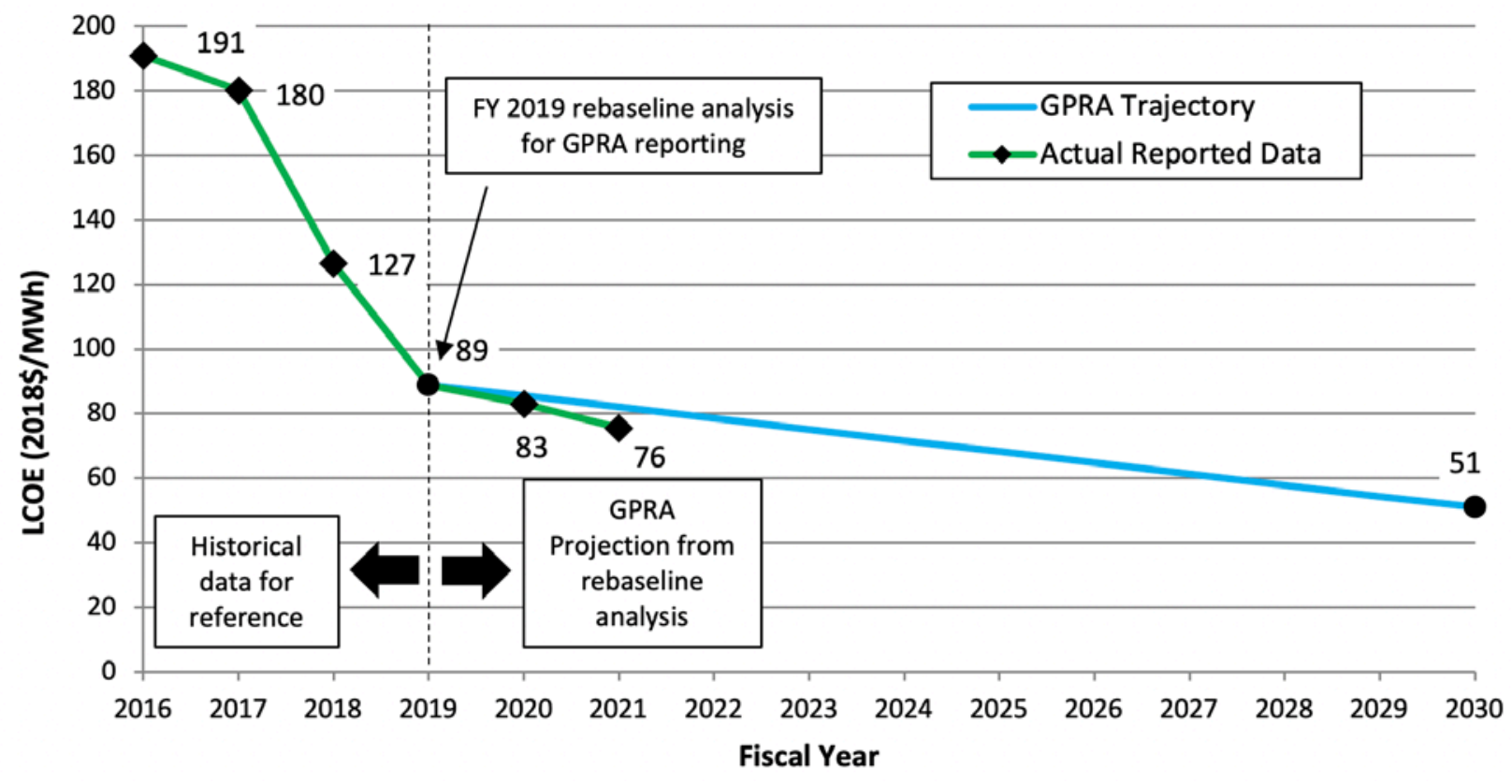

Figure 17. Fixed-bottom wind GPRA cost trajectories for LCOE

The reduction in the estimated LCOE ("GPRA goal") between FY 2019 and FY 2030 is categorized as various cost components: O\&M expenditures (\$17/MWh), CapEx components (i.e., wind turbine, electric system, and support structure; $\$ 12 / \mathrm{MWh}$ ), and improvements in AEP (\$9/MWh). These categories and their respective cost reductions are shown in Figure 18.

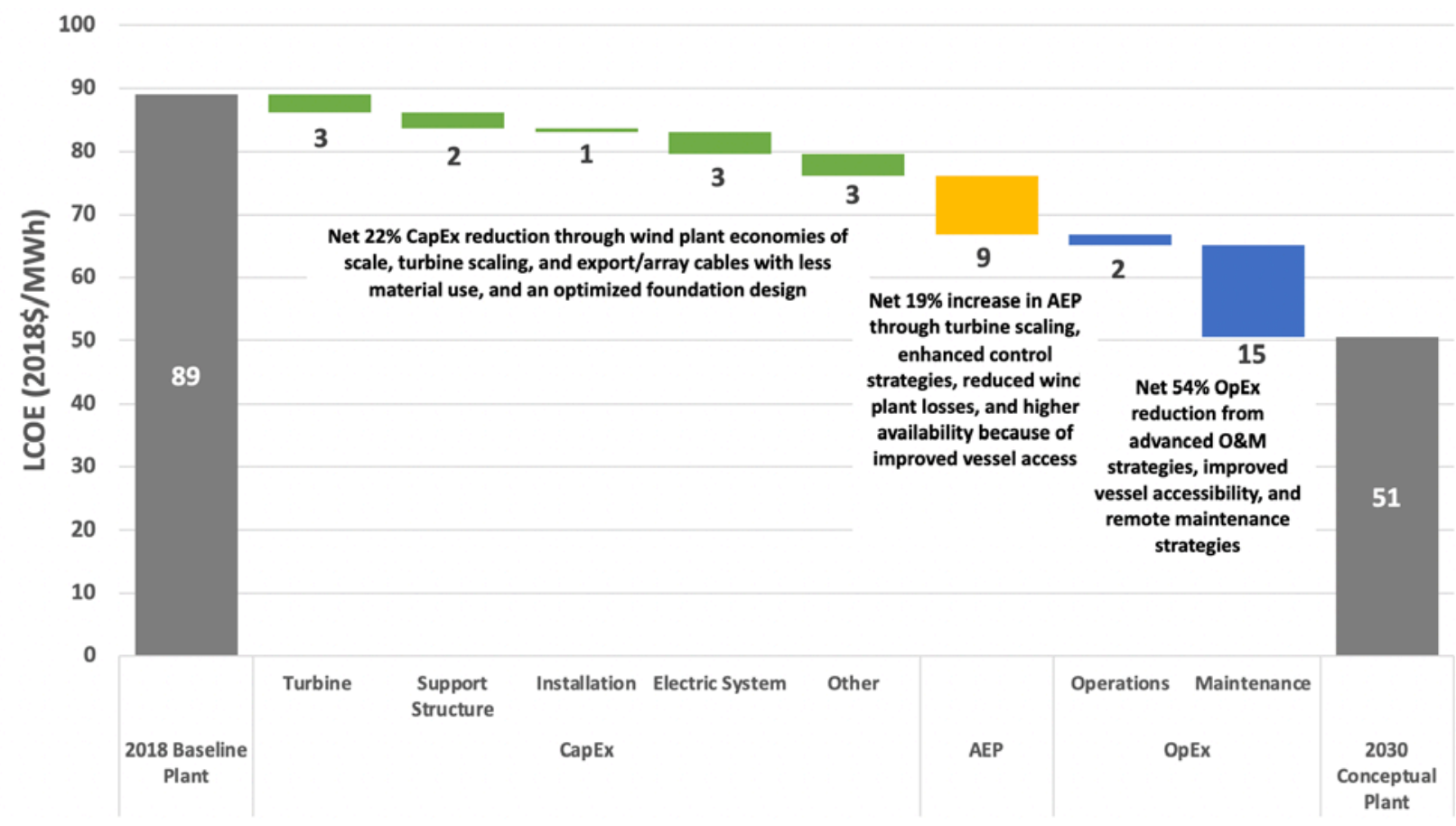

Figure 18. Fixed-bottom cost reductions in GPRA cost trajectories for LCOE 
Although DOE had no official GPRA reporting requirement for floating offshore wind energy costs at the time of this writing, we still include a value for 2030 floating LCOE obtained in the same manner as the 2030 target for fixed-bottom offshore wind costs. Figure 19 illustrates the projected cost reduction potential for floating offshore wind relative to a 2018 baseline.

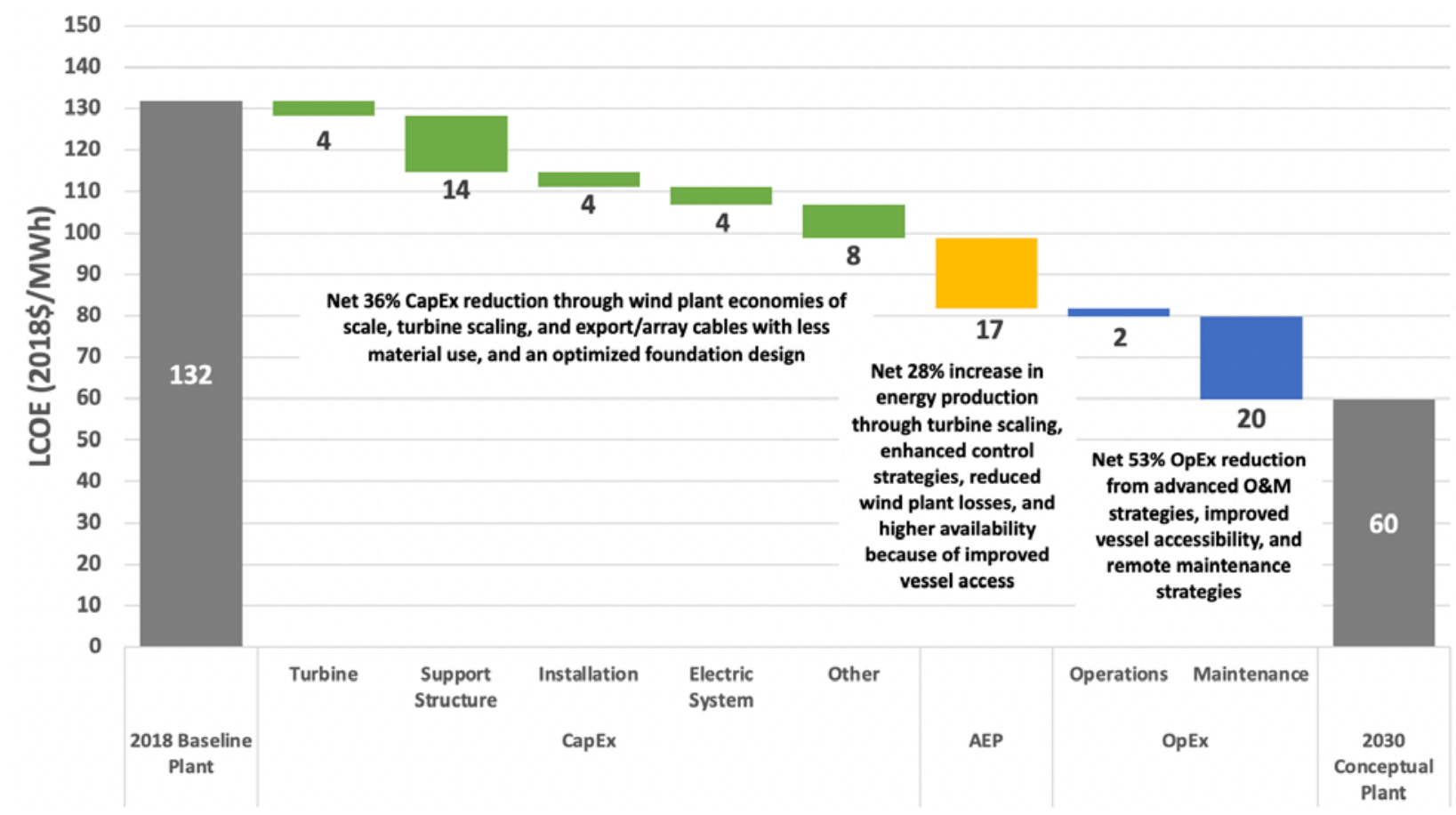

Figure 19. Floating cost reduction trajectories for LCOE 


\section{Distributed Wind Energy}

The distributed wind energy reference projects are intended to represent wind sites suitable for residential and commercial-scale wind turbines found in the United States. For the purposes of this report, distributed wind technology size classes are binned into discrete representations: 20 $\mathrm{kW}$ for residential and $100 \mathrm{~kW}$ for commercial (Lantz et al. 2016). The representative project size for the residential and commercial classes assumes the installation of a single wind turbine. In this year's report, the residential and commercial distributed wind reference project LCOE estimates are primarily informed by the 2019 market data from Orrell et al. (2020) because the market data for distributed wind energy projects in 2020 only comprised retrofits or upgrades (Orrell et al. 2021). With the absence of newly installed project data in 2020, we had to assume the CapEx, O\&M, and net energy production estimates using the "2019 Cost of Wind Energy Review" (Stehly et al. 2020). However, this report incorporates financial changes experienced in 2020 that are used to calculate LCOE. A summary of the financial changes and LCOE values are summarized in this section with additional reference project details presented in Appendix B.

\subsection{Distributed Wind Finance}

Financing assumptions refer to the cost of interest and other carrying charges, corporate taxes, and depreciation (represented by the FCR in this report) that are applied to the total CapEx. To capture the financing structure and costs, we used a fixed charge rate for the LCOE equation. Additional details describing FCR are presented in Section 4.5. Distributed wind finance is the single LCOE input parameter changed from last year's distributed wind cost assumptions by applying a change to the nominal debt interest rate from 3.6\% reported in the "2019 Cost of Wind Energy Review" (Stehly et al. 2020) to 2.61\%.

\subsubsection{Discount Rate}

Typically, various financial terms, such as the cost of debt or equity, are captured in the discount rate, which is in turn used to estimate the cost of energy. For this analysis, the discount rate is calculated as the after-tax WACC, and it is presumed that the reported yields for equity are aftertax yields and can be used directly in the WACC calculation. The cost of debt (as a value) is also reported, but because interest on debt is tax deductible, an effective corporate marginal tax rate is used to determine an after-tax cost of debt for the discount rate calculation. The cost of capital gives a basis for WACC assumptions for the representative wind projects and results in a nominal WACC of 5.16\%. This WACC was derived assuming a debt fraction of $60 \%$ from Lantz et al. (2016), a nominal debt interest rate of $2.61 \%$, a nominal return on equity of $10 \%$, and a $25.7 \%$ tax rate. Further details on the blended tax rate are presented in Section 4.5.1. Each actual project, however, has a unique risk profile, financing terms, and ownership structure. For this reason, a single WACC representing the distributed wind energy installations should be viewed cautiously and used to illustrate general market trends and conditions only.

The inflation rate has been set to $2.5 \%$ and aligns with the inflation rate provided in NREL's Annual Technology Baseline. Discount rates are initially calculated in nominal after-tax USD, and an estimate of inflation is used to calculate a discount rate in real after-tax USD. 


\subsubsection{Economic Evaluation Metrics}

In the economic evaluation of wind energy investments there are two important metrics: the CRF and FCR, with details provided in Section 4.5.2. For the economic evaluation of the residential and commercial projects, analysts assumed the residential host-owned representative project uses a 20-year straight-line depreciation schedule and the commercial/industrial host-owned project uses a 5-year MACRS depreciation schedule.

Table 23 presents the estimated WACC, CRF, and FCR in nominal and real terms using a project design lifetime of 25 years, and a net present value depreciation factor of $59.9 \%$ for the residential project (assuming a 20-year straight-line depreciation schedule) and $87.1 \%$ for the commercial project (assuming a 5-year MACRS depreciation schedule).

Table 23. Summary of Distributed Wind Reference Projects' Economic Evaluation Metrics

\begin{tabular}{|lcc|cc|} 
& \multicolumn{2}{c|}{ Residential $(20 \mathrm{~kW})$} & \multicolumn{2}{c|}{ Commercial } \\
& Nominal & Real & Nominal & Real \\
\hline WACC $(\%)$ & $5.16 \%$ & $2.60 \%$ & $5.16 \%$ & $2.60 \%$ \\
\hline CRF $(\%)$ & $7.21 \%$ & $5.49 \%$ & $7.21 \%$ & $5.49 \%$ \\
\hline FCR $(\%)$ & $8.21 \%$ & $6.25 \%$ & $7.53 \%$ & $5.73 \%$ \\
\hline
\end{tabular}

\subsection{Distributed Wind Levelized Cost of Energy}

We calculated the LCOE for the representative distributed wind projects using the formulation presented in NREL's Annual Technology Baseline and the representative turbine technology parameters, site conditions, wind resource, and cost estimates (i.e., CapEx, FCR, OpEx, and AEP). The LCOE value for the representative 2020 residential project is estimated at $\$ 151 / \mathrm{MWh}$ and $\$ 99 / \mathrm{MWh}$ for the representative commercial project.

Table 24 and Table 25 summarize the costs for the primary components on a per-kilowatt and per-megawatt-hour basis for the residential and commercial projects, respectively. The graphics in Figure 20 illustrate the LCOE breakdown for the primary LCOE components (i.e., turbine CapEx, BOS CapEx, and O\&M) of the representative residential and commercial wind energy projects. 
Table 24. Summary of Inputs and Reference Project LCOE for 2020 Residential Distributed Wind

\begin{tabular}{|c|c|c|}
\hline & $\begin{array}{c}\text { 20-kW Residential } \\
\text { Wind Turbine } \\
\text { (\$/kW) }\end{array}$ & $\begin{array}{l}\text { 20-kW Residential } \\
\text { Wind Turbine } \\
\text { (\$/MWh) }\end{array}$ \\
\hline Turbine CapEx & 2,575 & 62.4 \\
\hline Balance-of-system CapEx & 3,100 & 75.1 \\
\hline Total CapEx & 5,675 & 137.5 \\
\hline OpEx (\$/kW/yr) & 35 & 13.6 \\
\hline FCR (real) [\%] & \multicolumn{2}{|c|}{$6.2 \%$} \\
\hline Net AEP (kWh/kW/yr) & \multicolumn{2}{|c|}{2,580} \\
\hline Net capacity factor (\%) & \multicolumn{2}{|c|}{$29.5 \%$} \\
\hline TOTAL LCOE (\$/MWh) & \multicolumn{2}{|c|}{151} \\
\hline
\end{tabular}

Table 25. Summary of Inputs and Reference Project LCOE for 2020 Commercial Distributed Wind

\begin{tabular}{|c|c|c|}
\hline & $\begin{array}{c}\text { 100-kW Commercial } \\
\text { Wind Turbine } \\
(\$ / \mathbf{k W})\end{array}$ & $\begin{array}{l}\text { 100-kW Commercial } \\
\text { Wind Turbine } \\
\text { (\$/MWh) }\end{array}$ \\
\hline Turbine CapEx & 2,530 & 51.0 \\
\hline Balance-of-system CapEx & 1,770 & 35.7 \\
\hline Total CapEx & 4,300 & 86.6 \\
\hline OpEx (\$/kW/yr) & 35 & 12.3 \\
\hline FCR (real) [\%] & \multicolumn{2}{|c|}{$5.7 \%$} \\
\hline Net AEP (kWh/kW/yr) & \multicolumn{2}{|c|}{2,846} \\
\hline Net capacity factor (\%) & \multicolumn{2}{|c|}{$32.5 \%$} \\
\hline TOTAL LCOE (\$/MWh) & \multicolumn{2}{|c|}{99} \\
\hline
\end{tabular}



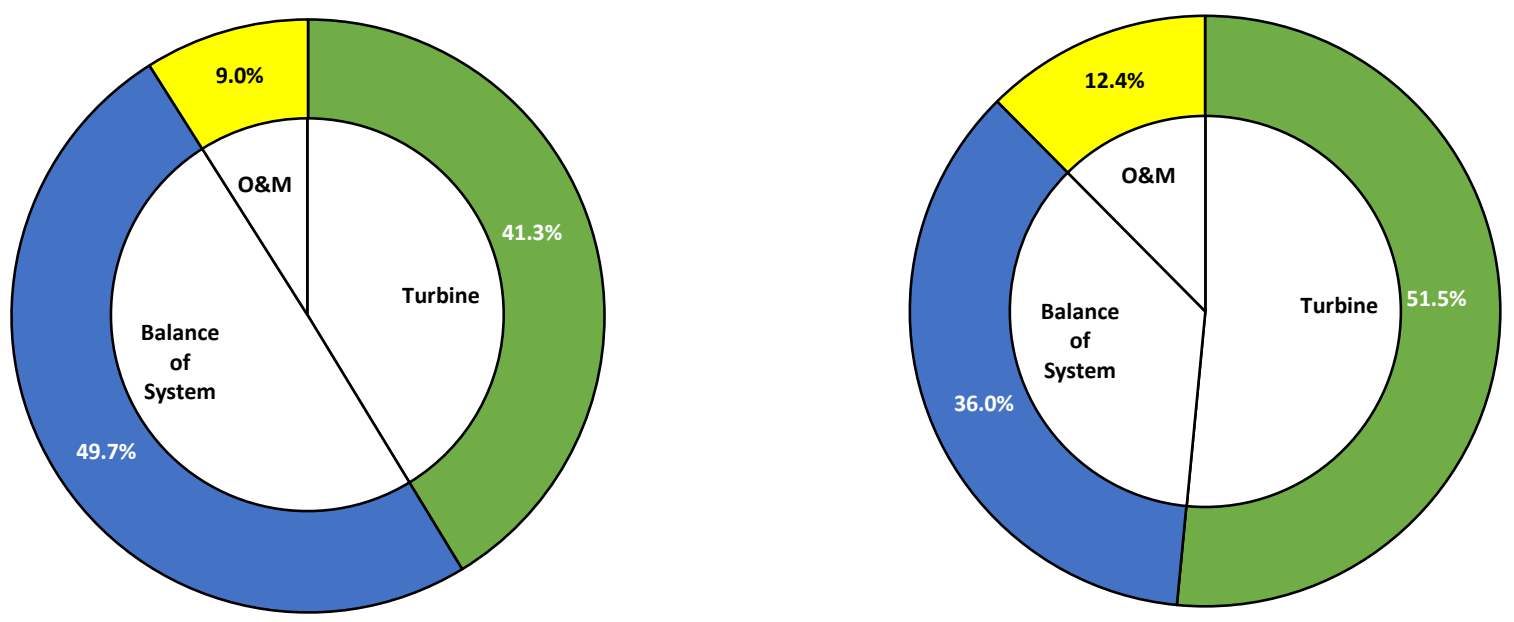

Figure 20. Component-level LCOE contribution for the 2020 residential (left) and commercial (right) distributed wind reference projects operating for 25 years

Note: Empirical data and cost model representation for residential and commercial distributed wind energy projects are limited; hence, detailed component-level LCOE contributions are not presented in this report. 


\section{Conclusions and Future Work}

This report presents a snapshot of the levelized cost of land-based, offshore, and distributed wind energy using empirically derived and modeled data representative of 2020 market conditions. Scenario planning and modeling activities often focus on one number (or cost) for land-based, offshore, and distributed wind LCOE. In reality, the cost of these wind energy technologies varies regionally across the United States and other parts of the world (Table 26).

Notably, the LCOE analysis presented is only one way to measure the cost of wind energy. It does not include other costs and price issues that influence a given wind project's viability, such as regional transmission upgrades and interconnection costs, environmental impacts, military constraints, or other areas of consideration (e.g., public policy, consumer costs, energy prices, or public acceptance). In addition, these LCOE estimates do not reflect the value of electricity, incentives, or other policy mechanisms (such as production tax credits or investment tax credits) that affect the sales price of electricity produced from wind energy projects.

Table 26. Range of LCOE for U.S. Land-Based and Offshore Wind in 2020

\begin{tabular}{|c|c|c|c|c|c|c|}
\hline & \multicolumn{3}{|c|}{ Land-Based Wind } & \multicolumn{3}{|c|}{ Offshore Wind } \\
\hline & Low & Reference & High & Low & Reference & High \\
\hline CapEx $(\$ / k W)$ & 1,000 & 1,462 & 2,000 & 2,045 & 3,756 & 6,059 \\
\hline OpEx (\$/kW/year) & 30 & 43 & 60 & 59 & 117 & 176 \\
\hline Net capacity factor (\%) & $24 \%$ & $42 \%$ & $56 \%$ & $35 \%$ & $49 \%$ & $50 \%$ \\
\hline Discount rate (nominal) [\%] & $4.2 \%$ & $5.2 \%$ & $6.3 \%$ & $4.0 \%$ & $5.3 \%$ & $6.6 \%$ \\
\hline Operational life (years) & 15 & 25 & 35 & 15 & 25 & 35 \\
\hline LCOE (\$/MWh) & 26 & 34 & 60 & 70 & 127 & 172 \\
\hline
\end{tabular}


The analysis and findings in this report helped generate the following conclusions:

- LCOE estimates continue to show a downward trend from the " 2010 Cost of Wind Energy Review" (Tegen et al. 2012) to 2020. Compared to the 2010 report, LCOE has decreased by $59 \%$ for land-based wind and $71 \%$ for fixed-bottom offshore wind. ${ }^{20}$

- We observed the reference project LCOE for land-based installations to be $\$ 34 / \mathrm{MWh}$; the full range of single-variable, land-based sensitivity estimates cover \$26-\$60/MWh.

- The reference offshore LCOE project estimates are $\$ 77 / \mathrm{MWh}$ for fixed-bottom substructures and $\$ 129 / \mathrm{MWh}$ for floating substructures, with a single-variable sensitivity range of $\$ 54-\$ 108 / \mathrm{MWh}$ for fixed bottom and $\$ 71-\$ 173 / \mathrm{MWh}$ for floating. This range is mostly influenced by the large variation in CapEx $(\$ 2,045-\$ 6,059 / \mathrm{kW})$ reported by project developers and is partly a function of differences in water depth and distance to shore.

- The residential distributed wind reference system LCOE was evaluated at $\$ 151 / \mathrm{MWh}$ and $\$ 99 / \mathrm{MWh}$ for the commercial distributed wind reference system. The single-variable sensitivity analysis was not performed in this year's report because new distributed wind project data were not available in 2020, but indicative LCOE ranges can be found in the "2019 Cost of Wind Energy Review" (Stehly et al. 2020).

- The range of LCOE calculated for the more than 9,000 GW of theoretical land-based wind capacity ranges from $\$ 24 / \mathrm{MWh}$ to beyond $\$ 175 / \mathrm{MWh}$, with an estimated LCOE range of $\$ 29-\$ 62 / \mathrm{MWh}$ for the projects installed in 2020. For fixed-bottom and floating offshore wind technology, an LCOE range between $\$ 67 / \mathrm{MWh}$ and $\$ 233 / \mathrm{MWh}$ is estimated for approximately 5,430 GW of theoretical capacity for all major U.S. coastal regions (excluding Alaska and Hawaii). The fixed-bottom representative offshore site is on the lower end of this range at $\$ 77 / \mathrm{MWh}$, whereas the floating representative site is near the middle of the range at $\$ 129 / \mathrm{MWh}$.

- The 2021 GPRA target for land-based wind energy, set in 2015, is $\$ 44 / \mathrm{MWh}$ compared to the actual LCOE estimate of $\$ 31 / \mathrm{MWh}$ in 2015 USD. ${ }^{21}$ For fixed-bottom offshore wind, the GPRA target for 2021 is $\$ 82 / \mathrm{MWh}$ compared to the actual LCOE estimate of \$76/MWh in 2018 USD. $^{22}$

NREL continues to strive for a better understanding of costs associated with many components of wind turbines and their related systems. Ongoing collaboration with industry, growing data sets, and enhanced modeling capabilities are expected to continue, leading to better insights and increased awareness of current and future wind power system and component costs. Future updates to this report are anticipated to help maintain a perspective on costs that is grounded in real-time market changes and offer greater insight into the costs and performance of individual components related to the wind electric generation system. In addition, these reports are intended

\footnotetext{
${ }^{20}$ The LCOE values reported in the "2010 Cost of Wind Energy Review" were inflated from 2010 USD to 2020 USD assuming a $18.7 \%$ cumulative rate of inflation from the Bureau of Labor and Statistics (undated) for comparison.

${ }^{21}$ The 2021 GPRA target and actual levelized cost of energy values for land-based wind energy are reported in 2015 USD because WETO will report land-based wind values in 2015 USD.

${ }^{22}$ The 2021 GPRA target and actual levelized cost of energy values for offshore wind are reported in 2018 USD because WETO will report offshore wind values in 2018 USD.
} 
to provide greater clarity regarding wind energy costs and the effects of changes in specific variables on LCOE. The data and tools developed from this work will be used to help inform projections, goals, and improvement opportunities. As the industry evolves and matures, these data provide current representative project costs and LCOE estimates for scenario planning, modeling, and goal setting.

Future work entails three primary objectives: 1) continuing to enhance data representing marketbased costs, performance, and technology trends to reflect actual wind industry experience, 2) enhancing the fidelity of LandBOSSE, ORBIT, and scaling cost models to estimate individual wind power plant components, and 3 ) understanding sensitivities to factors, such as regional differences, site characteristics, and technology choices. In 2022 and beyond, NREL will continue to work with industry and national laboratory partners to obtain project-specific data to validate and improve models. 


\section{References}

Beiter, P., W. Musial, A. Smith, L. Kilcher, R. Damiani, M. Maness, S. Sirnivas, T. Stehly, V. Gevorgian, M. Mooney, G. Scott. 2016. A Spatial-Economic Cost Reduction Pathway Analysis for U.S. Offshore Wind Energy Development from 2015-2030 (Technical Report). Golden, CO: National Renewable Energy Laboratory (NREL). NREL/TP-6A20-66579. https://www.nrel.gov/docs/fy16osti/66579.pdf.

Beiter, P., W. Musial, L. Kilcher, M. Maness, A. Smith. 2017. An Assessment of the Economic Potential of Offshore Wind in the United States from 2015 to 2030 (Technical Report). Golden, CO: National Renewable Energy Laboratory (NREL). NREL/TP-6A20-67675. https://www.nrel.gov/docs/fy17osti/67675.pdf.

Bolinger, M. 2014. "An Analysis of the Costs, Benefits, and Implications of Different Approaches to Capturing the Value of Renewable Energy Tax Incentives." Lawrence Berkeley National Laboratory. https://emp.lbl.gov/publications/analysis-costs-benefits-and.

Bureau of Labor and Statistics. Undated. "CPI Inflation Calculator.” Accessed September 2017. https://www.bls.gov/data/\#calculators.

Bureau of Ocean Energy Management. 2019. "Lease and Grant Information.” Accessed December 2020. https://www.boem.gov/Lease-and-Grant-Information/.

Dykes, K., M. Hand, T. Stehly, P. Veers, M. Robinson, E. Lantz. 2017. Enabling the SMART Wind Power Plant of the Future Through Science-Based Innovation (Technical Report). Golden, CO: National Renewable Energy Laboratory (NREL). NREL/TP-5000-68123. https://www.nrel.gov/docs/fy17osti/68123.pdf.

Eberle, Annika, Owen Roberts, Alicia Key, Parangat Bhaskar, and Katherine Dykes. 2019. NREL's Balance-of-System Cost Model for Land-Based Wind (Technical Report). Golden, CO: National Renewable Energy Laboratory. NREL/TP-6A20-72201. https://www.nrel.gov/docs/fy19osti/72201.pdf.

Feldman, D., M. Bolinger, and P. Schwabe. 2020. Current and Future Costs of Renewable Energy Project Finance Across Technologies (Technical Report). Golden, CO: National Renewable Energy Laboratory (NREL). NREL/TP-6A20-76881. https://www.nrel.gov/docs/fy20osti/76881.pdf.

GE Renewable Energy. 2018. "GE announces Haliade-X, the world's most powerful offshore wind turbine." Accessed June 2018. https://www.genewsroom.com/press-releases/ge-announceshaliade-x-worlds-most-powerful-offshore-wind-turbine-284260.

Gilman, P., B. Maurer, L. Feinberg, A. Duerr, L. Peterson, W. Musial, P. Beiter, J. Golladay, J. Stromberg, I. Johnson, D. Boren, A. Moore. 2016. National Offshore Wind Strategy: Facilitating the Development of the Offshore Wind Industry in the United States. DOE/GO-102016-4866. U.S. Department of Energy, Washington, D.C. (US). http://energy.gov/sites/prod/files/2016/09/f33/National-Offshore-Wind-Strategy-report09082016.pdf. 
International Electrotechnical Commission. 2020. Accessed September 2020.

https://www.iec.ch/.

Lantz, E., B. Sigrin, M. Gleason, R. Preus, I. Baring-Gould. 2016. Assessing the Future of Distributed Wind: Opportunities for Behind-the Meter Projects (Technical Report). Golden, CO: National Renewable Energy Laboratory (NREL). NREL/TP-6A20-

67337. https://www.nrel.gov/docs/fy17osti/67337.pdf.

Maclaurin, G., N. Grue, A. Lopez, D. Heimiller, M. Rossol, G. Buster, and T. Williams. 2019. The Renewable Energy Potential (reV) Model: A Geospatial Platform for Technical Potential and Supply Curve Modeling. Golden, CO: National Renewable Energy Laboratory. NREL/TP6A20-73067. https://www.nrel.gov/docs/fy19osti/73067.pdf.

Maples, B., G. Saur, M. Hand, R. van de Pietermen, T. Obdam. 2013. Installation, Operation, and Maintenance Strategies to Reduce the Cost of Offshore Wind Energy (Technical Report). Golden, CO: National Renewable Energy Laboratory (NREL). NREL/TP-5000-57403. http://www.nrel.gov/docs/fy13osti/57403.pdf.

REVE. 2019. "MHI Vestas Installs First V164-9.5 MW wind Turbine at Northwester 2 wind power." December 18, 2019. https://www.evwind.es/2019/12/18/mhi-vestas-installs-first-v1649-5-mw-wind-turbine-at-northwester-2-wind-power/72585.

MingYang. 2021. "Leading innovation: MingYang Smart Energy launches MySE 16.0-242, the world's largest offshore Hybrid Drive wind turbine." MingYang Smart Energy. Last Modified August 20, 2021. http://www.myse.com.cn/en/jtxw/info.aspx?itemid=825.

Moné, C., A. Smith, B. Maples, and M. Hand. 2015a. 2013 Cost of Wind Energy Review (Technical Report). Golden, CO: National Renewable Energy Laboratory (NREL). NREL/TP5000-63267. http://www.nrel.gov/docs/fy15osti/63267.pdf.

Moné, C., T. Stehly, B. Maples, and E. Settle. 2015b. 2014 Cost of Wind Energy Review (Technical Report). Golden, CO: National Renewable Energy Laboratory (NREL). NREL/TP6A20-64281. http://www.nrel.gov/docs/fy16osti/64281.pdf.

Moné, C., M. Hand, M. Bolinger, J. Rand, D. Heimiller, J. Ho. 2017. 2015 Cost of Wind Energy Review (Technical Report). Golden, CO: National Renewable Energy Laboratory (NREL). NREL/TP-6A20-66861. https://www.nrel.gov/docs/fy17osti/66861.pdf.

Musial, W., P. Beiter, D. Heimiller, and G. Scott. 2016. 2016 Offshore Wind Energy Resource Assessment for the United States (Technical Report). Golden, CO: National Renewable Energy Laboratory (NREL). NREL/TP-5000-66599. http://www.nrel.gov/docs/fy16osti/66599.pdf.

Musial, W., P. Beiter, P. Schwabe, T. Tian, T. Stehly, P. Spitsen. 2017. 2016 Offshore Wind Technologies Market Report. DOE/GO-102017-5031. U.S. Department of Energy, Washington, D.C. (US). https://energy.gov/sites/prod/files/2017/08/f35/2016\%20Offshore\%20Wind $\% 20$ Technologies $\% 2$ 0Market $\% 20$ Report.pdf. 
Musial, W., P. Beiter, P. Spitsen, J. Nunemaker, V. Gevorgian. 2019. 2018 Offshore Wind Market Report. DOE/GO-102019-5192. U.S. Department of Energy, Washington, D.C. (US). https://www.energy.gov/eere/wind/downloads/2018-offshore-wind-market-report.

Musial, W., P. Spitsen, P. Beiter, P. Duffy, M. Marquis, A. Cooperman, R. Hammond, and M. Shields. 2021. Offshore Wind Market Report: 2021 Edition. DOE/GO-102021-5614. U.S. Department of Energy, Washington, D.C. (US). https://www.energy.gov/sites/default/files/202108/Offshore\%20Wind\%20Market\%20Report\%202021\%20Edition Final.pdf.

National Renewable Energy Laboratory (NREL). (Internal, n.d.). Offshore Wind Database.

NREL. (Internal, n.d.). Land-Based-Wind Balance of System Model.

NREL. (n.d.). "Annual Technology Baseline and Standard Scenarios." Accessed December 2020. https://atb.nrel.gov/.

NREL. (n.d.). "System Advisor Model (SAM).” Accessed December 2020. https://sam.nrel.gov/.

NREL. (n.d.). "Wind Integration National Dataset Toolkit.” Accessed December 2020. https://www.nrel.gov/grid/wind-toolkit.html.

NREL. 2021. "2021 Annual Technology Baseline.” Golden, CO: National Renewable Energy Laboratory. https://atb.nrel.gov/.

Nunemaker, Jake, Matt Shields, Robert Hammond, and Patrick Duffy. 2020. ORBIT: Offshore Renewables Balance-of-System and Installation Tool. Golden, CO: National Renewable Energy Laboratory. NREL/TP-5000-77081. https://www.nrel.gov/docs/fy20osti/77081.pdf.

Orrell, A., D. Preziuso, S. Morris, J. Homer. 2020. 2019 Distributed Wind Data Summary. PNNL-30168. Pacific Northwest National Laboratory, Richland, WA. https://www.pnnl.gov/sites/default/files/media/file/2019\%20Distributed\%20Wind\%20Data\%20S ummary-10Aug20.pdf.

Orrell, A., K. Kazimierczuk, L. Sheridan. 2021. Distributed Wind Market Report: 2021 Edition. U.S. Department of Energy, Office of Energy Efficiency and Renewable Energy. Washington, D.C. (US). https://www.energy.gov/eere/wind/articles/distributed-wind-market-report-2021edition-released.

Pietermen, R., H. Braam, T. Obdam, L. Rademakers, T. van der Zee. 2011. Optimisation of maintenance strategies for offshore wind farms. Energy research Centre of the Netherlands. https://publicaties.ecn.n1/PdfFetch.aspx?nr=ECN-M--11-103.

Shields, M., P. Beiter, J. Nunemaker, A. Cooperman, and P. Duffy. 2021. "Impacts of turbine and plant upsizing on the levelized cost of energy for offshore wind." Applied Energy, Volume 298, September 2021, pg 117-189. https://doi.org/10.1016/j.apenergy.2021.117189. 
Shields, M., and J. Nunemaker. 2020. "Process-Based Balance-of-System Cost Modeling for Offshore Wind Power Plants in the United States: Preprint." Presented at NAWEA/WindTech 2019. Golden, CO: National Renewable Energy Laboratory (NREL). NREL/CP-5000-74933. https://www.nrel.gov/docs/fy20osti/74933.pdf.

Short, W., D. J. Packey, and T. Holt. 1995. A Manual for the Economic Evaluation of Energy Efficiency and Renewable Energy Technologies (Technical Report). Golden, CO: National Renewable Energy Laboratory (NREL). NREL/TP-462-5176.

http://www.nrel.gov/docs/legosti/old/5173.pdf.

Siemens Gamesa. 2020. "Powered by change: Siemens Gamesa launches 14 MW offshore Direct Drive turbine with 222-meter rotor." May 19, 2020. https://www.siemensgamesa.com/newsroom/2020/05/200519-siemens-gamesa-turbine-14-222dd.

Stehly, T., D. Heimiller, G. Scott. 2017. 2016 Cost of Wind Energy Review (Technical Report). NREL/TP-6A20-70363. National Renewable Energy Laboratory (NREL), Golden, CO (US). https://www.nrel.gov/docs/fy18osti/70363.pdf.

Stehly, T., P. Beiter, D. Heimiller, G. Scott. 2018. 2017 Cost of Wind Energy Review (Technical Report). NREL/TP-6A20-72167. National Renewable Energy Laboratory (NREL), Golden, CO (US). https://www.nrel.gov/docs/fy18osti/72167.pdf.

Stehly, T., P. Beiter. 2019. 2018 Cost of Wind Energy Review (Technical Report). Golden, CO: National Renewable Energy Laboratory (NREL). NREL/TP-5000-74598. https://www.nrel.gov/docs/fy20osti/74598.pdf.

Stehly, T., P. Beiter, P. Duffy. 2020. 2019 Cost of Wind Energy Review (Technical Report). Golden, CO: National Renewable Energy Laboratory (NREL). NREL/TP-5000-78471. https://www.nrel.gov/docs/fy21osti/78471.pdf.

Tegen, S., M. Hand, B. Maples, E. Lantz, S. Schwabe, A. Smith. 2012. 2010 Cost of Wind Energy Review (Technical Report). Golden, CO: National Renewable Energy Laboratory (NREL). NREL/TP-5000-52920. http://www.nrel.gov/docs/fy120sti/52920.pdf.

Tegen, S., E. Lantz, M. Hand, B. Maples, A. Smith, P. Schwabe. 2013. 2011 Cost of Wind Energy Review (Technical Report). Golden, CO: National Renewable Energy Laboratory (NREL). NREL/TP-5000-56266. http://www.nrel.gov/docs/fy13osti/56266.pdf.

UL. Undated. https://aws-dewi.ul.com/software/openwind/.

U.S. Department of Energy. 2015. Wind Vision: A New Era for Wind Power in the United States. DOE/GO-102015-4557. U.S. Department of Energy Office of Energy Efficiency and Renewable Energy. Washington, D.C. (US).

http://www.energy.gov/sites/prod/files/WindVision_Report_final.pdf. 
Vestas. 2021. "Vestas launches the V236-15.0 MW to set new industry benchmark and take next step towards leadership in offshore wind." Vestas Wind Systems A/S. Last modified February 10, 2021. https://www.vestas.com/en/media/company-news?l=42\&n=3886820\#!NewsView.

Vineyard Wind. 2021. "Vineyard Wind 1 Becomes the First Commercial Scale Offshore Wind Farm in the US to Achieve Financial Close." September 15, 2021.

https://www.vineyardwind.com/press-releases/2021/9/15/vineyard-wind-1-becomes-the-firstcommercial-scale-offshore-wind-farm-in-the-us-to-achieve-financial-close.

Wiser, R. and M. Bolinger. 2021. Land-Based Wind Market Report: 2021 Edition. Lawrence Berkeley National Laboratory. https://emp.lbl.gov/wind-technologies-market-report.

Wiser, R., M. Bolinger, and E. Lantz. 2019. "Assessing wind power operating costs in the United States: Results from a survey of wind industry experts." Renewable Energy Focus 30: 46-57. https://www.sciencedirect.com/science/article/pii/S1755008419300092. 


\section{Appendix A. Offshore Wind Reference Site Development}

In this report, we define reference sites for fixed-bottom and floating offshore wind technology. These reference sites are intended to reflect site conditions that represent near- to medium-term U.S. project development and are based on a replicable methodology.

We conducted the following steps to identify a reference site for fixed-bottom and floating offshore wind technology, respectively:

1. For each offshore wind region (as specified in Gilman et al. 2016), a 600-megawatt (MW) cohesive area within each Bureau of Ocean Energy Management lease and Call Area delineation (Bureau of Ocean Energy Management 2019) that is closest to shore (measured by direct distance) was identified, while:

- Only considering lease area(s) if at least one is available within an offshore wind region

- Consider Call Area(s) if there is no designated lease area

- Assuming a wind turbine spacing of $3 \mathrm{MW} /$ square kilometer (Musial et al. 2016).

2. Define "reference site" parameters by averaging key spatial parameters across the areas defined in step \#1 for each offshore wind region:

○ Water depth

$\circ \quad$ Wind speed

○ Gross and net capacity factor

- Array efficiency

- Distance from site to cable landfall

- Distance from cable landfall to onshore substation

- Distance from site to construction port

○ Distance from site to operation and maintenance port

$\circ$ Wave height.

3. Designated the "North Atlantic" offshore wind region to be the reference site for fixed bottom and the "Pacific Coast" to represent floating offshore wind technology. This determination was made because these regions experience the highest commercial activity for these technology types (Musial et al. 2019).

4. Specify the spatial parameters from step \#2 in the Offshore Wind Cost Model to determine the levelized cost of energy.

Results for the spatial parameters calculated for each regional reference sites are shown in Table A1. 
Table A1. Spatial Parameters for Regional Reference Sites

\begin{tabular}{|c|c|c|c|c|c|c|c|c|c|c|}
\hline & Depth & $\begin{array}{c}\text { Wind } \\
\text { Speed }\end{array}$ & $\begin{array}{c}\text { GCF } \\
\mathbf{6} \\
\mathbf{M W}\end{array}$ & $\mathbf{N C F}$ & $\begin{array}{c}\text { Array } \\
\text { Efficiency }\end{array}$ & $\begin{array}{c}\text { Site to } \\
\text { Cable } \\
\text { Landfall }\end{array}$ & $\begin{array}{c}\text { Distance } \\
\text { Cable } \\
\text { Landfall to } \\
\text { Substation }\end{array}$ & $\begin{array}{c}\text { Site to } \\
\text { CP }\end{array}$ & $\begin{array}{c}\text { Site to } \\
\text { OP }\end{array}$ & $\begin{array}{c}\text { Average } \\
\text { HS }\end{array}$ \\
\hline Units & $m$ & $m / s$ & $\%$ & $\%$ & $\%$ & $k m$ & $k m$ & $k m$ & $k m$ & $m$ \\
\hline $\begin{array}{c}\text { North } \\
\text { Atlantic }\end{array}$ & 34 & 9.03 & $58 \%$ & $48 \%$ & $92 \%$ & 50 & 9 & 116 & 114 & 1.2 \\
\hline $\begin{array}{c}\text { South } \\
\text { Atlantic }\end{array}$ & 30 & 8.58 & $53 \%$ & $44 \%$ & $92 \%$ & 51 & 7 & 118 & 118 & 1.2 \\
\hline $\begin{array}{c}\text { Pacific } \\
\text { Coast }\end{array}$ & 739 & 8.22 & $48 \%$ & $38 \%$ & $93 \%$ & 36 & 8 & 189 & 189 & 2.4 \\
\hline Hawaii & 764 & 8.59 & $52 \%$ & $43 \%$ & $94 \%$ & 18 & 10 & 36 & 36 & 1.6 \\
\hline
\end{tabular}

Note: The "North Atlantic" serves as fixed bottom and the "Pacific Coast" serves as the floating offshore wind technology reference site. The "South Atlantic" and "Hawaii" are included for reference only.

Acronyms in Table A1: CP: construction port; GCF: gross capacity factor; HS: significant annual average wave height; km: kilometer(s); m: meter(s); m/s: meters per second; NCF: net capacity factor; OP:

operations port. 


\section{Appendix B. Summary of Assumptions for 2020 Reference Projects}

A summary of the capital expenditures, technology characteristics, annual energy production, operation and maintenance expenditures, and finance assumptions for each of the reference projects presented in this report is provided in this appendix. The information appears in separate tables for land-based wind (Table B1), fixed-bottom offshore wind (Table B2), floating offshore wind (Table B3), residential distributed wind (Table B4), and commercial distributed wind (Table B5) reference projects.

Table B1. Land-Based-Wind Reference Project Levelized Cost of Energy Assumptions

\begin{tabular}{|c|c|c|c|}
\hline Assumption & Units & Value & Notes \\
\hline \multicolumn{4}{|c|}{ Wind power plant characteristics } \\
\hline Wind plant capacity & $\begin{array}{l}\text { megawatts } \\
(\mathrm{MW})\end{array}$ & 200 & \multirow{2}{*}{$\begin{array}{l}\text { Representative of commercial-scale } \\
\text { projects }\end{array}$} \\
\hline Number of wind turbines & & 73 & \\
\hline Turbine rating & MW & 2.76 & \multirow{3}{*}{$\begin{array}{l}\text { “Land-Based Wind Market Report: } 2021 \\
\text { Edition” (Wiser and Bolinger 2021) }\end{array}$} \\
\hline Rotor diameter & meters $(\mathrm{m})$ & 124.9 & \\
\hline Hub height & $\mathrm{m}$ & 90.2 & \\
\hline Specific power & $\begin{array}{l}\text { watts } \\
(\mathrm{W}) / \text { square } \\
\text { meter }\left(\mathrm{m}^{2}\right)\end{array}$ & 225 & Calculation \\
\hline Cut-in wind speed & $\begin{array}{c}\text { meters per } \\
\text { second }(\mathrm{m} / \mathrm{s})\end{array}$ & 3 & \multirow{2}{*}{ Typical wind turbine characteristics } \\
\hline Cut-out wind speed & $\mathrm{m} / \mathrm{s}$ & 25 & \\
\hline $\begin{array}{l}\text { Annual average wind speed } \\
\text { at } 50 \mathrm{~m}\end{array}$ & $\mathrm{~m} / \mathrm{s}$ & 7.25 & Reference site wind speed \\
\hline $\begin{array}{l}\text { Annual average wind speed } \\
\text { at hub height }\end{array}$ & $\mathrm{m} / \mathrm{s}$ & 7.89 & $\begin{array}{l}\text { Between International Electrotechnical } \\
\text { Class (IEC) class III }(7.5 \mathrm{~m} / \mathrm{s}) \text { and IEC class II } \\
(8.5 \mathrm{~m} / \mathrm{s})\end{array}$ \\
\hline Weibull k factor & & 2.0 & \\
\hline Shear exponent & & 0.143 & Shear for neutral stability conditions \\
\hline $\begin{array}{l}\text { Altitude above mean sea } \\
\text { level }\end{array}$ & $\mathrm{m}$ & 450 & Altitude at turbine foundation \\
\hline Losses & $\%$ & $15 \%$ & \multirow{2}{*}{$\begin{array}{l}\text { "Wind Vision" (U.S. Department of Energy } \\
\text { 2015) }\end{array}$} \\
\hline Availability & $\%$ & $98 \%$ & \\
\hline Net energy capture & $\begin{array}{c}\text { megawatt- } \\
\text { hour (MWh)/ } \\
\text { MW/year (yr) }\end{array}$ & 3,703 & \multirow[t]{2}{*}{ System Advisor Model calculation } \\
\hline Net capacity factor & $\%$ & $42.3 \%$ & \\
\hline \multicolumn{4}{|c|}{ Capital Expenditures (CapEx) } \\
\hline Total CapEx & $\begin{array}{l}\text { dollars } \\
(\$) / \text { kilowatt } \\
(\mathrm{kW})\end{array}$ & 1,462 & $\begin{array}{l}\text { "Land-Based Wind Market Report: } 2021 \\
\text { Edition" (Wiser and Bolinger 2021) }\end{array}$ \\
\hline Wind turbine & $\$ / \mathrm{kW}$ & 1,030 & \multirow{3}{*}{2015 Cost and Scaling Model } \\
\hline Rotor module & $\$ / \mathrm{kW}$ & 313 & \\
\hline Blades & $\$ / \mathrm{kW}$ & 203 & \\
\hline
\end{tabular}




\begin{tabular}{|c|c|c|c|}
\hline Assumption & Units & Value & Notes \\
\hline Pitch assembly & $\$ / \mathrm{kW}$ & 63 & \\
\hline Hub assembly & $\$ / \mathrm{kW}$ & 48 & \\
\hline Nacelle module & $\$ / \mathrm{kW}$ & 512 & \\
\hline $\begin{array}{l}\text { Nacelle structural } \\
\text { assembly }\end{array}$ & $\$ / \mathrm{kW}$ & 103 & \\
\hline Drivetrain assembly & $\$ / \mathrm{kW}$ & 205 & \\
\hline $\begin{array}{l}\text { Nacelle electrical } \\
\text { assembly }\end{array}$ & $\$ / \mathrm{kW}$ & 166 & \\
\hline Yaw assembly & $\$ / \mathrm{kW}$ & 38 & \\
\hline Tower module & $\$ / \mathrm{kW}$ & 204 & \\
\hline Balance of system & $\$ / \mathrm{kW}$ & 322 & \multirow{7}{*}{$\begin{array}{l}\text { Land-based Balance of System Systems } \\
\text { Engineering [LandBOSSE] (Eberle et al. } \\
\text { 2019) }\end{array}$} \\
\hline Development & $\$ / \mathrm{kW}$ & 23 & \\
\hline $\begin{array}{l}\text { Engineering and project } \\
\text { management }\end{array}$ & $\$ / \mathrm{kW}$ & 10 & \\
\hline Foundation & $\$ / \mathrm{kW}$ & 75 & \\
\hline Site access and staging & $\$ / \mathrm{kW}$ & 40 & \\
\hline $\begin{array}{l}\text { Assembly and } \\
\text { installation }\end{array}$ & $\$ / \mathrm{kW}$ & 41 & \\
\hline Electrical infrastructure & $\$ / \mathrm{kW}$ & 132 & \\
\hline Soft costs & $\$ / \mathrm{kW}$ & 110 & \\
\hline Construction finance & $\$ / \mathrm{kW}$ & 22 & Project construction over 3 years \\
\hline Contingency & $\$ / \mathrm{kW}$ & 88 & $6 \%$ of total CapEx \\
\hline \multicolumn{4}{|c|}{ Operational Expenditures (OpEx) } \\
\hline Total OpEx & $\$ / \mathrm{kW} / \mathrm{yr}$ & 43 & $\begin{array}{l}\text { "Assessing Wind Power Operating Costs in } \\
\text { the United States" (Wiser et al. 2019) }\end{array}$ \\
\hline \multicolumn{4}{|c|}{ Financials } \\
\hline Project design life & Years & 25 & $\begin{array}{l}\text { Project life for Government Performance } \\
\text { and Results Act (GPRA) reporting }\end{array}$ \\
\hline $\begin{array}{l}\text { Tax rate (combined state and } \\
\text { federal) }\end{array}$ & $\%$ & $25.7 \%$ & \multirow{2}{*}{$\begin{array}{l}2021 \text { Annual Technology Baseline (NREL's } \\
\text { Annual Technology Baseline and Standard } \\
\text { Scenarios web page: atb.nrel.gov) }\end{array}$} \\
\hline Inflation rate & $\%$ & $2.5 \%$ & \\
\hline $\begin{array}{l}\text { Interest during construction } \\
\text { (nominal) }\end{array}$ & $\%$ & $2.61 \%$ & $\begin{array}{l}\text { "Land-Based Wind Market Report: } 2021 \\
\text { Edition" (Wiser and Bolinger 2021) }\end{array}$ \\
\hline Construction finance factor & $\%$ & $102 \%$ & Calculation \\
\hline Debt fraction & $\%$ & $47.9 \%$ & \multirow{3}{*}{$\begin{array}{l}\text { "Land-Based Wind Market Report: } 2021 \\
\text { Edition" (Wiser and Bolinger 2021) }\end{array}$} \\
\hline Debt interest rate (nominal) & $\%$ & $2.61 \%$ & \\
\hline Return on equity (nominal) & $\%$ & $8.25 \%$ & \\
\hline $\begin{array}{l}\text { Weighted-average cost of } \\
\text { capital (WACC) (nominal; } \\
\text { after-tax) }\end{array}$ & $\%$ & $5.23 \%$ & \multirow{4}{*}{ Calculation } \\
\hline WACC (real; after-tax) & $\%$ & $2.66 \%$ & \\
\hline $\begin{array}{l}\text { Capital recovery factor } \\
\text { (nominal; after-tax) }\end{array}$ & $\%$ & $7.26 \%$ & \\
\hline $\begin{array}{l}\text { Capital recovery factor (real; } \\
\text { after-tax) }\end{array}$ & $\%$ & $5.53 \%$ & \\
\hline Depreciable basis & $\%$ & $100 \%$ & Simplified depreciation schedule \\
\hline
\end{tabular}




\begin{tabular}{|c|c|c|c|}
\hline Assumption & Units & Value & Notes \\
\hline Depreciation schedule & & $\begin{array}{c}\text { 5-year Modified Accelerated } \\
\text { Cost Recovery System } \\
\text { (MACRS) }\end{array}$ & $\begin{array}{l}\text { MACRS is standard for U.S. wind energy } \\
\text { projects }\end{array}$ \\
\hline $\begin{array}{l}\text { Depreciation adjustment } \\
\text { (net present value [NPV]) }\end{array}$ & $\%$ & $86.9 \%$ & \multirow{4}{*}{ Calculation } \\
\hline Project finance factor & $\%$ & $105 \%$ & \\
\hline $\begin{array}{l}\text { Fixed charge rate (FCR) } \\
\text { (nominal) }\end{array}$ & $\%$ & $7.59 \%$ & \\
\hline FCR (real) & $\%$ & $5.78 \%$ & \\
\hline Levelized cost of energy & $\$ / \mathrm{MWh}$ & 34 & Calculation \\
\hline
\end{tabular}

Table B2. Fixed-Bottom Offshore Wind Reference Project Levelized Cost of Energy Assumptions

\begin{tabular}{|c|c|c|c|}
\hline Assumption & Units & Value & Notes \\
\hline \multicolumn{4}{|c|}{ Wind power plant characteristics } \\
\hline Wind plant capacity & MW & 600 & $\begin{array}{l}\text { Representative of commercial-scale } \\
\text { projects }\end{array}$ \\
\hline Number of wind turbines & Number & 75 & Calculation \\
\hline Turbine rating & MW & 8 & \multirow{3}{*}{$\begin{array}{l}\text { "Offshore Wind Market Report: } 2021 \\
\text { Edition" (Musial et al. 2021) }\end{array}$} \\
\hline Rotor diameter & $\mathrm{m}$ & 159 & \\
\hline Hub height & $\mathrm{m}$ & 102.1 & \\
\hline Specific power & $\mathrm{W} / \mathrm{m}^{2}$ & 403 & Calculation \\
\hline Water depth & $\mathrm{m}$ & 34 & \multirow{9}{*}{$\begin{array}{l}\text { Representative fixed-bottom offshore } \\
\text { site for Cost of Energy Review }\end{array}$} \\
\hline Substructure type & & Monopile & \\
\hline Distance from shore & kilometers $(\mathrm{km})$ & 50 & \\
\hline Cut-in wind speed & $\mathrm{m} / \mathrm{s}$ & 3 & \\
\hline Cut-out wind speed & $\mathrm{m} / \mathrm{s}$ & 25 & \\
\hline Average annual wind speed at $50 \mathrm{~m}$ & $\mathrm{~m} / \mathrm{s}$ & 8.4 & \\
\hline Average annual wind speed at hub height & $\mathrm{m} / \mathrm{s}$ & 9.0 & \\
\hline Shear exponent & & 0.10 & \\
\hline Weibull k & & 2.1 & \\
\hline Total system losses & $\%$ & $15.7 \%$ & ORCA (based on Beiter et al. 2016) \\
\hline Gross energy capture & MWh/MW/year & 5,081 & Calculation \\
\hline Net energy capture & MWh/MW/year & 4,283 & \\
\hline Gross capacity factor & $\%$ & $58.0 \%$ & \multirow{2}{*}{ ORCA (based on Beiter et al. 2016) } \\
\hline Net capacity factor & $\%$ & $48.9 \%$ & \\
\hline \multicolumn{4}{|c|}{ CapEx } \\
\hline Total CapEx & $\$ / \mathrm{kW}$ & 3,756 & \\
\hline Wind turbine & $\$ / \mathrm{kW}$ & 1,301 & \multirow{3}{*}{$\begin{array}{l}\text { "Offshore Wind Market Report: } 2021 \\
\text { Edition" (Musial et al. 2021) }\end{array}$} \\
\hline Rotor nacelle assembly & $\$ / \mathrm{kW}$ & 1,119 & \\
\hline Tower & $\$ / \mathrm{kW}$ & 182 & \\
\hline
\end{tabular}




\begin{tabular}{|c|c|c|c|}
\hline Assumption & Units & Value & Notes \\
\hline Balance of system & $\$ / \mathrm{kW}$ & 1,782 & \multirow{14}{*}{$\begin{array}{l}\text { Balance of system (BOS) costs } \\
\text { computed with ORBIT (Nunemaker et } \\
\text { al. 2020) }\end{array}$} \\
\hline Development & $\$ / \mathrm{kW}$ & 85 & \\
\hline Project management & $\$ / \mathrm{kW}$ & 2 & \\
\hline Substructure and foundation & $\$ / \mathrm{kW}$ & 474 & \\
\hline Substructure & $\$ / \mathrm{kW}$ & 185 & \\
\hline Foundation & $\$ / \mathrm{kW}$ & 289 & \\
\hline Electrical infrastructure & $\$ / \mathrm{kW}$ & 662 & \\
\hline Array cable system & $\$ / \mathrm{kW}$ & 112 & \\
\hline Export cable system & $\$ / \mathrm{kW}$ & 370 & \\
\hline Grid connection & $\$ / \mathrm{kW}$ & 180 & \\
\hline Assembly and installation & $\$ / \mathrm{kW}$ & 390 & \\
\hline Turbine installation & $\$ / \mathrm{kW}$ & 212 & \\
\hline Substructure and foundation installation & $\$ / \mathrm{kW}$ & 178 & \\
\hline Lease price & $\$ / \mathrm{kW}$ & 170 & \\
\hline Soft costs & $\$ / \mathrm{kW}$ & 672 & \multirow{8}{*}{$\begin{array}{l}\text { Soft costs computed using same } \\
\text { methodology as ORCA (Beiter et al. } \\
\text { 2016) }\end{array}$} \\
\hline Insurance during construction & $\$ / \mathrm{kW}$ & 33 & \\
\hline Decommissioning bond & $\$ / \mathrm{kW}$ & 111 & \\
\hline Construction finance & $\$ / \mathrm{kW}$ & 145 & \\
\hline Sponsor contingency & $\$ / \mathrm{kW}$ & 350 & \\
\hline Procurement contingency & $\$ / \mathrm{kW}$ & 127 & \\
\hline Installation contingency & $\$ / \mathrm{kW}$ & 223 & \\
\hline Project completions/commissioning & $\$ / \mathrm{kW}$ & 33 & \\
\hline \multicolumn{4}{|c|}{ OpEx } \\
\hline Total OpEx & $\$ / \mathrm{kW} /$ year & 110 & \multirow{3}{*}{ ORCA (based on Beiter et al. 2016) } \\
\hline Operations (pretax) & $\$ / \mathrm{kW} /$ year & 30 & \\
\hline Maintenance & $\$ / \mathrm{kW} /$ year & 80 & \\
\hline \multicolumn{4}{|c|}{ Financials } \\
\hline Project design life & Years & 25 & $\begin{array}{l}\text { Offshore wind project life for GPRA } \\
\text { reporting }\end{array}$ \\
\hline Tax rate (combined state and federal) & $\%$ & $26 \%$ & \multirow{5}{*}{$\begin{array}{l}\text { Feldman et al. (2020) and NREL's } \\
\text { Annual Technology Baseline }\end{array}$} \\
\hline Inflation rate & $\%$ & $2.5 \%$ & \\
\hline Debt fraction & $\%$ & $67 \%$ & \\
\hline Debt interest rate (nominal) & $\%$ & $4.0 \%$ & \\
\hline Return on equity (nominal) & $\%$ & $10.0 \%$ & \\
\hline WACC (nominal; after-tax) & $\%$ & $5.3 \%$ & \multirow{4}{*}{ Calculation } \\
\hline WACC (real; after-tax) & $\%$ & $2.7 \%$ & \\
\hline Capital recovery factor (nominal; after-tax) & $\%$ & $7.3 \%$ & \\
\hline Capital recovery factor (real; after-tax) & $\%$ & $5.6 \%$ & \\
\hline Depreciable basis & $\%$ & $100 \%$ & Simplified depreciation schedule \\
\hline
\end{tabular}




\begin{tabular}{|c|c|c|c|}
\hline Assumption & Units & Value & Notes \\
\hline Depreciation schedule & & $\begin{array}{l}\text { 5-year } \\
\text { MACRS }\end{array}$ & Standard for U.S. wind projects \\
\hline Depreciation adjustment (NPV) & $\%$ & $86.8 \%$ & \multirow{4}{*}{ Calculation } \\
\hline Project finance factor & $\%$ & $105 \%$ & \\
\hline FCR (nominal) & $\%$ & $7.6 \%$ & \\
\hline FCR (real) & $\%$ & $5.8 \%$ & \\
\hline Levelized cost of energy & $\$ / \mathrm{MWh}$ & 77 & Calculation \\
\hline
\end{tabular}

Table B3. Floating Offshore Wind Reference Project LCOE Assumptions

\begin{tabular}{|c|c|c|c|}
\hline Assumption & Units & Value & Notes \\
\hline \multicolumn{4}{|c|}{ Wind power plant characteristics } \\
\hline Wind plant capacity & MW & 600 & Representative of commercial-scale projects \\
\hline Number of wind turbines & Number & 75 & Calculation \\
\hline Turbine rating & MW & 8 & \multirow{3}{*}{$\begin{array}{l}\text { “Offshore Wind Market Report: } 2021 \text { Edition" } \\
\text { (Musial et al. 2021) }\end{array}$} \\
\hline Rotor diameter & $\mathrm{m}$ & 159 & \\
\hline Hub height & $\mathrm{m}$ & 102.1 & \\
\hline Specific power & $\mathrm{W} / \mathrm{m}^{2}$ & 403 & Calculation \\
\hline Water depth & $\mathrm{m}$ & 739 & \multirow{9}{*}{$\begin{array}{l}\text { Representative floating site for Cost of Wind Energy } \\
\text { Review }\end{array}$} \\
\hline Substructure type & & Semisubmersible & \\
\hline Distance from shore & $\mathrm{km}$ & 36 & \\
\hline Cut-in wind speed & $\mathrm{m} / \mathrm{s}$ & 3 & \\
\hline Cut-out wind speed & $\mathrm{m} / \mathrm{s}$ & 25 & \\
\hline $\begin{array}{l}\text { Average annual wind speed at } \\
50 \mathrm{~m}\end{array}$ & $\mathrm{~m} / \mathrm{s}$ & 7.7 & \\
\hline $\begin{array}{l}\text { Average annual wind speed at } \\
\text { hub height }\end{array}$ & $\mathrm{m} / \mathrm{s}$ & 8.2 & \\
\hline Shear exponent & & 0.10 & \\
\hline Weibull k & & 2.1 & \\
\hline Total system losses & $\%$ & $20.8 \%$ & ORCA (based on Beiter et al. 2016) \\
\hline Gross energy capture & $\mathrm{MWh} / \mathrm{MW} / \mathrm{yr}$ & 4,205 & Calculation \\
\hline Net energy capture & $\mathrm{MWh} / \mathrm{MW} / \mathrm{yr}$ & 3,332 & \\
\hline Gross capacity factor & $\%$ & $48.0 \%$ & \multirow{2}{*}{ ORCA (based on Beiter et al. 2016) } \\
\hline Net capacity factor & $\%$ & $38.0 \%$ & \\
\hline \multicolumn{4}{|c|}{ CapEx } \\
\hline Total CapEx & $\$ / \mathrm{kW}$ & 5,351 & \\
\hline Wind turbine & $\$ / \mathrm{kW}$ & 1,301 & \multirow{3}{*}{$\begin{array}{l}\text { "Offshore Wind Market Report: } 2021 \text { Edition" } \\
\text { (Musial et al. 2021) }\end{array}$} \\
\hline Rotor nacelle assembly & $\$ / \mathrm{kW}$ & 1,119 & \\
\hline Tower & $\$ / \mathrm{kW}$ & 182 & \\
\hline Balance of system & $\$ / \mathrm{kW}$ & 3,234 & \\
\hline
\end{tabular}




\begin{tabular}{|c|c|c|c|}
\hline Assumption & Units & Value & Notes \\
\hline Development & $\$ / \mathrm{kW}$ & 85 & \multirow{11}{*}{$\begin{array}{l}\text { BOS costs computed with ORBIT (Nunemaker et al. } \\
\qquad 2020 \text { ) }\end{array}$} \\
\hline Project management & $\$ / \mathrm{kW}$ & 2 & \\
\hline $\begin{array}{l}\text { Substructure and } \\
\text { foundation }\end{array}$ & $\$ / \mathrm{kW}$ & 1,996 & \\
\hline Substructure & $\$ / \mathrm{kW}$ & 1,293 & \\
\hline Foundation & $\$ / \mathrm{kW}$ & 703 & \\
\hline Electrical infrastructure & $\$ / \mathrm{kW}$ & 679 & \\
\hline Array cable system & $\$ / \mathrm{kW}$ & 174 & \\
\hline Export cable system & $\$ / \mathrm{kW}$ & 323 & \\
\hline Grid connection & $\$ / \mathrm{kW}$ & 182 & \\
\hline $\begin{array}{l}\text { Assembly and } \\
\text { installation }\end{array}$ & $\$ / \mathrm{kW}$ & 302 & \\
\hline Lease price & $\$ / \mathrm{kW}$ & 170 & \\
\hline Soft costs & $\$ / \mathrm{kW}$ & 816 & \multirow{8}{*}{$\begin{array}{l}\text { Soft costs computed using same methodology as } \\
\text { ORCA (Beiter et al. 2016) }\end{array}$} \\
\hline $\begin{array}{l}\text { Insurance during } \\
\text { construction }\end{array}$ & $\$ / \mathrm{kW}$ & 49 & \\
\hline Decommissioning bond & $\$ / \mathrm{kW}$ & 97 & \\
\hline Construction finance & $\$ / \mathrm{kW}$ & 211 & \\
\hline Sponsor contingency & $\$ / \mathrm{kW}$ & 409 & \\
\hline Procurement contingency & $\$ / \mathrm{kW}$ & 215 & \\
\hline Installation contingency & $\$ / \mathrm{kW}$ & 194 & \\
\hline $\begin{array}{l}\text { Project } \\
\text { completions/commissionin } \\
\mathrm{g}\end{array}$ & $\$ / \mathrm{kW}$ & 49 & \\
\hline \multicolumn{4}{|c|}{ OpEx } \\
\hline Total OpEx & $\$ / \mathrm{kW} /$ year & 118 & \multirow{3}{*}{ ORCA (based on Beiter et al. 2016) } \\
\hline Operations (pretax) & $\$ / \mathrm{kW} /$ year & 30 & \\
\hline Maintenance & $\$ / \mathrm{kW} /$ year & 88 & \\
\hline \multicolumn{4}{|c|}{ Financials } \\
\hline Project design life & Years & 25 & $\begin{array}{l}\text { Offshore wind energy project life for GPRA } \\
\text { reporting }\end{array}$ \\
\hline $\begin{array}{l}\text { Tax rate (combined state and } \\
\text { federal) }\end{array}$ & $\%$ & $26 \%$ & \multirow{7}{*}{$\begin{array}{l}\text { Feldman et al. (2020) and NREL's Annual } \\
\text { Technology Baseline }\end{array}$} \\
\hline Federal & $\%$ & $21 \%$ & \\
\hline State & $\%$ & $4.7 \%$ & \\
\hline Inflation rate & $\%$ & $2.5 \%$ & \\
\hline Debt fraction & $\%$ & $67 \%$ & \\
\hline Debt interest rate (nominal) & $\%$ & $4.0 \%$ & \\
\hline Return on equity (nominal) & $\%$ & $10.0 \%$ & \\
\hline WACC (nominal; after-tax) & $\%$ & $5.3 \%$ & \multirow{3}{*}{ Calculation } \\
\hline WACC (real; after-tax) & $\%$ & $2.7 \%$ & \\
\hline $\begin{array}{l}\text { Capital recovery factor } \\
\text { (nominal; after-tax) }\end{array}$ & $\%$ & $7.3 \%$ & \\
\hline
\end{tabular}


Assumption

Units

Value

Notes

\begin{tabular}{|c|c|c|c|}
\hline $\begin{array}{l}\text { Capital recovery factor (real; } \\
\text { after-tax) }\end{array}$ & $\%$ & $5.6 \%$ & \\
\hline Depreciable basis & $\%$ & $100 \%$ & Simplified depreciation schedule \\
\hline Depreciation schedule & & 5-year MACRS & Standard for U.S. wind energy projects \\
\hline $\begin{array}{l}\text { Depreciation adjustment } \\
\text { (NPV) }\end{array}$ & $\%$ & $86.8 \%$ & \multirow{4}{*}{ Calculation } \\
\hline Project finance factor & $\%$ & $105 \%$ & \\
\hline FCR (nominal) & $\%$ & $7.6 \%$ & \\
\hline FCR (real) & $\%$ & $5.8 \%$ & \\
\hline Levelized cost of energy & $\$ / M W h$ & 129 & Calculation \\
\hline
\end{tabular}

Table B4. Residential Distributed Wind Reference Project LCOE Assumptions

\begin{tabular}{|c|c|c|c|}
\hline Assumption & Units & Value & Notes \\
\hline \multicolumn{4}{|c|}{ Wind power plant characteristics } \\
\hline Wind plant capacity & $\mathrm{kW}$ & 20 & \multirow{2}{*}{ Representative of residential distributed wind projects } \\
\hline Number of wind turbines & & 1 & \\
\hline Turbine rating & $\mathrm{kW}$ & 20 & \multirow{3}{*}{$\begin{array}{l}\text { "Assessing the Future of Distributed Wind: Opportunities for } \\
\text { Behind-the Meter Projects" (Lantz et al. 2016) }\end{array}$} \\
\hline Rotor diameter & $\mathrm{m}$ & 12.4 & \\
\hline Hub height & $\mathrm{m}$ & 30 & \\
\hline Specific power & $\mathrm{W} / \mathrm{m}^{2}$ & 166 & Calculation \\
\hline Cut-in wind speed & $\mathrm{m} / \mathrm{s}$ & 3 & \multirow{2}{*}{ Typical turbine characteristics } \\
\hline Cut-out wind speed & $\mathrm{m} / \mathrm{s}$ & 20 & \\
\hline $\begin{array}{l}\text { Annual average wind } \\
\text { speed at } 50 \mathrm{~m}\end{array}$ & $\mathrm{~m} / \mathrm{s}$ & 6.00 & Reference site wind speed \\
\hline $\begin{array}{l}\text { Annual average wind } \\
\text { speed at hub height }\end{array}$ & $\mathrm{m} / \mathrm{s}$ & 5.58 & IEC class IV \\
\hline Weibull k factor & & 2.0 & \\
\hline Shear exponent & & 0.143 & Shear for neutral stability conditions \\
\hline $\begin{array}{l}\text { Altitude above mean sea } \\
\text { level }\end{array}$ & $\mathrm{m}$ & 0 & Altitude at turbine foundation \\
\hline Losses & $\%$ & $7 \%$ & \multirow{2}{*}{$\begin{array}{l}\text { Informed by https://www.nrel.gov/wind/competitiveness- } \\
\text { improvement-project.html }\end{array}$} \\
\hline Availability & $\%$ & $95 \%$ & \\
\hline Net energy capture & $\begin{array}{c}\mathrm{kWh} / \mathrm{kW} / \mathrm{y} \\
\mathrm{r}\end{array}$ & 2,580 & \multirow{2}{*}{$\begin{array}{l}\text { Calculation in Openwind (UL website (undated) https:/aws- } \\
\text { dewi.ul.com/software/openwind/) }\end{array}$} \\
\hline Net capacity factor & $\%$ & $29.5 \%$ & \\
\hline \multicolumn{4}{|r|}{ CapEx } \\
\hline Total CapEx & $\$ / \mathrm{kW}$ & 5,675 & \\
\hline Wind turbine & $\$ / \mathrm{kW}$ & 2,575 & “2019 Distributed Wind Data Summary” (Orrell et al. 2020) \\
\hline Balance of system & $\$ / \mathrm{kW}$ & 3,100 & $\begin{array}{l}\text { "NREL's Balance-of-System Cost Model for Land-Based Wind" } \\
\text { (Eberle et al. 2019) }\end{array}$ \\
\hline & & & OpEx \\
\hline
\end{tabular}




\begin{tabular}{|c|c|c|c|}
\hline Assumption & Units & Value & Notes \\
\hline Total OpEx & $\$ / \mathrm{kW} /$ year & 35 & $\begin{array}{l}\text { "Assessing the Future of Distributed Wind: Opportunities for } \\
\text { Behind-the Meter Projects" (Lantz et al. 2016) }\end{array}$ \\
\hline \multicolumn{4}{|r|}{ Financials } \\
\hline Project design life & Years & 25 & Project life for GPRA reporting \\
\hline $\begin{array}{l}\text { Tax rate (combined state } \\
\text { and federal) }\end{array}$ & $\%$ & $25.7 \%$ & \multirow{2}{*}{$\begin{array}{l}2021 \text { Annual Technology Baseline (NREL's Annual Technology } \\
\text { Baseline and Standard Scenarios web page: atb.nrel.gov) }\end{array}$} \\
\hline Inflation rate & $\%$ & $2.5 \%$ & \\
\hline Debt fraction & $\%$ & $60 \%$ & $\begin{array}{l}\text { "Assessing the Future of Distributed Wind: Opportunities for } \\
\text { Behind-the Meter Projects" (Lantz et al. 2016) }\end{array}$ \\
\hline $\begin{array}{l}\text { Debt interest rate } \\
\text { (nominal) }\end{array}$ & $\%$ & $2.61 \%$ & $\begin{array}{l}\text { "Land-Based Wind Market Report: } 2021 \text { Edition" (Wiser and } \\
\text { Bolinger 2021) }\end{array}$ \\
\hline $\begin{array}{l}\text { Return on equity } \\
\text { (nominal) }\end{array}$ & $\%$ & $10 \%$ & "2019 Cost of Wind Energy Review" (Stehly et al. 2020) \\
\hline WACC (nominal; after-tax) & $\%$ & $5.16 \%$ & \multirow{4}{*}{ Calculation } \\
\hline WACC (real; after-tax) & $\%$ & $2.60 \%$ & \\
\hline $\begin{array}{l}\text { Capital recovery factor } \\
\text { (nominal; after-tax) }\end{array}$ & $\%$ & $7.21 \%$ & \\
\hline $\begin{array}{l}\text { Capital recovery factor } \\
\text { (real; after-tax) }\end{array}$ & $\%$ & $5.49 \%$ & \\
\hline Depreciable basis & $\%$ & $100 \%$ & Simplified depreciation schedule \\
\hline Depreciation schedule & $\begin{array}{c}20-y r \\
\text { straight } \\
\text { line }\end{array}$ & $\begin{array}{c}20-y r \\
\text { straight } \\
\text { line }\end{array}$ & \\
\hline $\begin{array}{l}\text { Depreciation adjustment } \\
\text { (NPV) }\end{array}$ & $\%$ & $59.9 \%$ & \multirow{4}{*}{ Calculation } \\
\hline Project finance factor & $\%$ & $114 \%$ & \\
\hline FCR (nominal) & $\%$ & $8.21 \%$ & \\
\hline FCR (real) & $\%$ & $6.25 \%$ & \\
\hline Levelized cost of energy & $\$ / M W h$ & 151 & Calculation \\
\hline
\end{tabular}

Table B5. Commercial Distributed Wind Reference Project LCOE Assumptions

\begin{tabular}{|c|c|c|c|}
\hline Assumption & Units & Value & Notes \\
\hline \multicolumn{4}{|c|}{ Wind power plant characteristics } \\
\hline Wind plant capacity & kW & 100 & \multirow{2}{*}{ Representative of residential distributed wind energy project } \\
\hline Number of wind turbines & & 1 & \\
\hline Turbine rating & $\mathrm{kW}$ & 100 & \multirow{3}{*}{$\begin{array}{l}\text { "Assessing the Future of Distributed Wind: Opportunities for Behind- } \\
\text { the Meter Projects" (Lantz et al. 2016) }\end{array}$} \\
\hline Rotor diameter & $\mathrm{m}$ & 27.6 & \\
\hline Hub height & $\mathrm{m}$ & 40 & \\
\hline Specific power & $\mathrm{W} / \mathrm{m}^{2}$ & 167 & Calculation \\
\hline Cut-in wind speed & $\mathrm{m} / \mathrm{s}$ & 3 & \multirow{2}{*}{ Typical wind turbine characteristics } \\
\hline Cut-out wind speed & $\mathrm{m} / \mathrm{s}$ & 25 & \\
\hline $\begin{array}{l}\text { Annual average wind speed } \\
\text { at } 50 \mathrm{~m}\end{array}$ & $\mathrm{~m} / \mathrm{s}$ & 6.00 & Reference site wind speed \\
\hline
\end{tabular}




\begin{tabular}{|c|c|c|c|}
\hline Assumption & Units & Value & Notes \\
\hline $\begin{array}{l}\text { Annual average wind speed } \\
\text { at hub height }\end{array}$ & $\mathrm{m} / \mathrm{s}$ & 5.81 & IEC class IV \\
\hline Weibull k factor & & 2.0 & \\
\hline Shear exponent & & 0.143 & Shear for neutral stability conditions \\
\hline $\begin{array}{l}\text { Altitude above mean sea } \\
\text { level }\end{array}$ & $\mathrm{m}$ & 0 & Altitude at wind turbine foundation \\
\hline Losses & $\%$ & $7 \%$ & \multirow{2}{*}{$\begin{array}{l}\text { Informed by NREL's Competitiveness Improvement Project website: } \\
\text { https://www.nrel.gov/wind/competitiveness-improvement- } \\
\text { project.html }\end{array}$} \\
\hline Availability & $\%$ & $95 \%$ & \\
\hline Net energy capture & $\begin{array}{c}\mathrm{kWh} / \mathrm{kW} \\
/ \mathrm{yr}\end{array}$ & 2,846 & \multirow{2}{*}{$\begin{array}{l}\text { Calculation in Openwind (UL website (undated): https://aws- } \\
\text { dewi.ul.com/software/openwind/) }\end{array}$} \\
\hline Net capacity factor & $\%$ & $32.5 \%$ & \\
\hline \multicolumn{4}{|r|}{ CapEx } \\
\hline Total CapEx & $\$ / \mathrm{kW}$ & 4,300 & \\
\hline Wind turbine & $\$ / \mathrm{kW}$ & 2,530 & “2019 Distributed Wind Data Summary” (Orrell et al. 2020) \\
\hline Balance of system & $\$ / \mathrm{kW}$ & 1,770 & $\begin{array}{l}\text { "NREL's Balance-of-System Cost Model for Land-Based Wind" (Eberle } \\
\text { et al. 2019) }\end{array}$ \\
\hline \multicolumn{4}{|r|}{ OpEx } \\
\hline Total OpEx & $\$ / \mathrm{kW} / \mathrm{yr}$ & 35 & $\begin{array}{l}\text { "Assessing the Future of Distributed Wind: Opportunities for Behind- } \\
\text { the Meter Projects" (Lantz et al. 2016) }\end{array}$ \\
\hline \multicolumn{4}{|r|}{ Financials } \\
\hline Project design life & Years & 25 & Project life for GPRA reporting \\
\hline $\begin{array}{l}\text { Tax rate (combined state } \\
\text { and federal) }\end{array}$ & $\%$ & $25.7 \%$ & \multirow{2}{*}{$\begin{array}{l}2021 \text { Annual Technology Baseline (NREL's Annual Technology } \\
\text { Baseline and Standard Scenarios web page: atb.nrel.gov) }\end{array}$} \\
\hline Inflation rate & $\%$ & $2.5 \%$ & \\
\hline Debt fraction & $\%$ & $60 \%$ & $\begin{array}{l}\text { "Assessing the Future of Distributed Wind: Opportunities for Behind- } \\
\text { the Meter Projects" (Lantz et al. 2016) }\end{array}$ \\
\hline $\begin{array}{l}\text { Debt interest rate } \\
\text { (nominal) }\end{array}$ & $\%$ & $2.61 \%$ & $\begin{array}{l}\text { "Land-Based Wind Market Report: } 2021 \text { Edition" (Wiser and Bolinger } \\
\text { 2021) }\end{array}$ \\
\hline Return on equity (nominal) & $\%$ & $10 \%$ & “2019 Cost of Wind Energy Review" (Stehly et al. 2020) \\
\hline WACC (nominal; after-tax) & $\%$ & $5.16 \%$ & \multirow{4}{*}{ Calculation } \\
\hline WACC (real; after-tax) & $\%$ & $2.60 \%$ & \\
\hline $\begin{array}{l}\text { Capital recovery factor } \\
\text { (nominal; after-tax) }\end{array}$ & $\%$ & $7.21 \%$ & \\
\hline $\begin{array}{l}\text { Capital recovery factor } \\
\text { (real; after-tax) }\end{array}$ & $\%$ & $5.49 \%$ & \\
\hline Depreciable basis & $\%$ & $100 \%$ & Simplified depreciation schedule \\
\hline Depreciation schedule & $\begin{array}{l}\text { 5-year } \\
\text { MACRS }\end{array}$ & $\begin{array}{l}\text { 5-year } \\
\text { MACRS }\end{array}$ & MACRS assumed for commercial project \\
\hline $\begin{array}{l}\text { Depreciation adjustment } \\
\text { (NPV) }\end{array}$ & $\%$ & $87.1 \%$ & \multirow{4}{*}{ Calculation } \\
\hline Project finance factor & $\%$ & $104 \%$ & \\
\hline FCR (nominal) & $\%$ & $7.53 \%$ & \\
\hline FCR (real) & $\%$ & $5.73 \%$ & \\
\hline Levelized cost of energy & $\$ / \mathrm{MWh}$ & 99 & Calculation \\
\hline
\end{tabular}

